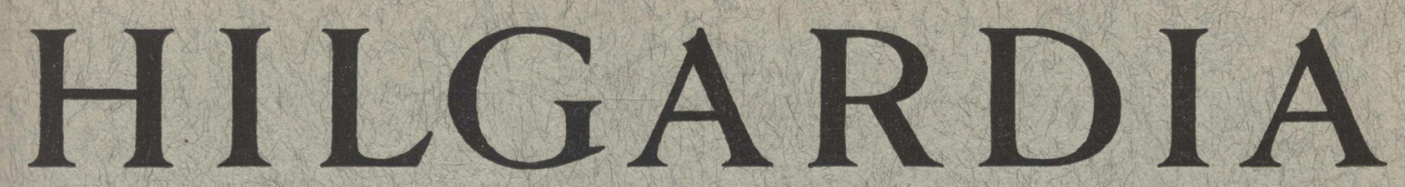

A Journal of Agricultural Science Publisbed by the California Agricultural Experiment Station

\title{
HERBICIDAL PROPERTIES OF OILS
}

A. S. CRAFTS and H. G. REIBER 


\section{CONTENTS}

PAGE

Introduction .............. 77

Oils as herbicides ............. 77

Specificity of oils............ 77

Fortified oils ............... 78

New types of oils........... 78

Scope and purpose of this study.... 78

Composition of oils .......... 78

Classification of oils .......... 78

Saturated hydrocarbons ......... 79

Unsaturated hydrocarbons ...... 81

Aromatic hydrocarbons ......... 81

Other compounds in oils........ 82

Oil refining .............. 82

Nonpetroleum oils........... 83

Toxicity of oils .......... 83

Toxicity types............. 84

Selectivity .............. 84

Laboratory and greenhouse methods .............. 85

Oil fractions ............. 86

Comparison of stove oil, gasoline, and Diesel oil ...............

Narrow distillation fractions.......

Toxicity of straight-run and cracked gasolines ................

Kerosene and mineral seal oil.....

Heavy fuel oil. ..............

Isoparaffins ................

Acid treatment and solvent

extraction .............. 100

Unsulfonated residues of stove oil and Diesel oil .............. 100

Products of solvent extraction..... 105

Coke-still residues ........... 108

Olefinic and aromatic compounds.. 108

Relation of toxicity to boiling range in Edeleanu extract .. 112

Toxicity of Badger-type distillate cuts .................. 112

Temperature cuts of Avon Weed Killer.................. 115

Storage and refluxing ........ 116

Toxicity change of gasolines on standing ................. 116

Toxicity of refluxed samples...... 116

Toxicity of stored fractions...... 117

Pure compounds ............ 120

Toxicity of aromatic compounds... 120

Toxicity of benzenes.......... 123

Aromatic and cyclic hydrocarbons. 125

Mercaptans ................. 127

Tests on chain and cyclic hydrocarbons
Selectivity of oils

PAGB

. . . . . . . 128

Type of compound........... 129

Selective action on onions....... 131

Susceptibility of weed species to selective oils ............ 131

Physical properties of oil and

application methods....... 133

Properties of water and oils..... 133

Properties of plant surfaces...... 133

Creeping of oils............ 134

Role of application method...... 135

Suitability of commercial fractions to weed control............ 136

Properties of emulsions ........ 136

Uses of emulsions............ 137

Tests of emulsions........... 137

Emulsions on flax........... 137

Emulsions on onions........... 138

Use of sulfur in Diesel-oil emulsions 139

Fortified oils and oil emulsions . 141

Slow action of heavy oils........ 141

Oil-tolerant weed species........ 141

Fortification of oils........... 141

Tests of fortified-oil emulsions.... 142

Quantitative relations of oil and fortifying agent ............ 144

Volume relations of emulsions.... 145

Oil carriers for 2,4-D ........ 145

Discussion of oil toxicity ....... 146

Nature of oil toxicity......... 146

Types of oil toxicity.......... 147

Oxidation of oils............. 148

On the production of a nontoxic diluent................. 149

Oil selectivity .............. 150

Character of oil toxicity........ 150

Summary ................ 152

Oil fractions ............. 152

Acid treatment and solvent extraction ................. 152

Toxicity and boiling range of

Edeleanu extract........... 153

Storage and refluxing......... 153

Pure compounds ............ 153

Selectivity of oils............ 153

Physical properties of oil and application methods ............ 154

Properties of emulsions.......... 154

Fortified oils and oil emulsions.... 155

Literature cited ........... 156 


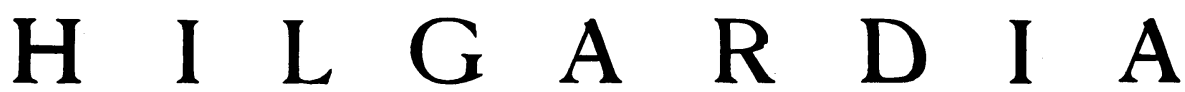 \\ A Journal of Agricultural Science Published by \\ the California Agricultural Experiment Station

\section{HERBICIDAL PROPERTIES OF OILS ${ }^{1,2}$}

\author{
A. S. CRAFTS ${ }^{3}$ and H. G. REIBER ${ }^{4}$
}

\section{INTRODUCTION}

Oils as Herbicides. Oils of many types have been employed as herbicides. In the West, petroleum fractions have been most popular; and of these Diesel oil, stove oil, and smudge-pot oil have been applied in greatest volume. They have been used to kill general weed growth on roadsides and railway roadbeds in order to prevent the spread of fires. They are a means of eliminating the vegetation that depletes soil-moisture reserves in citrus groves; of destroying the weeds that harbor insect and fungus pests on ditchbanks, fence rows, and similar untilled areas; and of burning undesirable growth on irrigation ditches. Over 3 million gallons have been consumed annually in California for these purposes, and the use is expanding rapidly. Recently stove oil has been applied as a selective spray against weeds in vegetable crops, notably carrots, celery, and parsley.

The herbicidal use of oils has developed through many years. Early practices utilized acid sludge, acid tar, Edeleanu extracts, and other by-products of oil refining that had little commercial value. In the East, residues from coal and wood distillation, various petroleum fractions, gas oils, and similar lowcost products have been applied to weeds. Availability and hauling cost have largely determined distribution and the extent of use.

Increased demand for oils as motor and heating fuel has been accompanied by improvement in the quality of these products ; herbicidal toxicity has likewise been altered. Unsaturated compounds, particularly the aromatics, tend to make fuel oils burn sooty, and they have antiknock properties that are undesirable in a Diesel fuel. These compounds are toxic to plants, and their removal decreases the killing action of an oil. One problem is that of providing enough toxicity per unit volume to kill plants with the amount required to wet them.

Specificity of Oils. Weed species vary in their response to oil injury. Members of the Umbelliferae are notably tolerant of oils; and the crop plants

\footnotetext{
${ }^{1}$ Received for publication October 10, 1946.

2 Many of the samples used in these studies were provided by the Shell Development Company, the Tidewater Associated Oil Company, the Dow Chemical Company, and Standard Agricultural Chemicals, Inc. The writers wish to express their appreciation for this coöperation. We are also indebted to Mr. H. W. Allinger, Principal Laboratory Technician, Division of Chemistry, for most of the analytical work reported in this paper.

${ }^{3}$ Professor of Botany and Botanist in the Experiment Station.

* Associate Professor of Chemistry and Associate Chemist in the Experiment Station.
} 
carrot, celery, parsnip, parsley, and anise are so resistant that stove oil is used as a selective spray to kill weeds in them. Even these crops are injured by oils heavier than stove oil. Toxicity also varies with temperature, being higher during hot sunny weather than on cool days.

Oil residues are distasteful on crops. If a selective stove-oil spray has been applied late in the growing season, there may be insufficient time for the residue to be dissipated and the product may be unacceptable on the market. On carrots the stove-oil spray must be applied while the seedlings have one to four true leaves; later applications leave an oily residue undesirable in the cooked vegetable. The question is often asked: Can the manufacturer produce an oil that will be nontoxic to carrots and will leave no objectionable residue? Another common inquiry is whether oils might serve as selective herbicides on other crops.

Fortified Oils. Research workers on herbicides have discovered several chemicals that will make oils more toxic and will broaden their applicability to oil-tolerant weed species. Since the use of such "fortifying" agents is relatively new, information is needed concerning the type most desirable for various weed populations, the quantities most economical to use, the kind of oil best suited to combine with them, and the proper amendments required to render the herbicidal mixture most compatible with the methods of application.

New Types of Oils. Finally, new oil fractions and even new oils are being made available for weed control. The users need help in fitting these new products into the general schemes of weed control employed in the regions where each product will be marketed.

Scope and Purpose of This Study. As this brief introduction shows, there are many uses for oils in weed control, and oil products fulfill needs that other chemicals cannot satisfy. For efficiency, however, the properties of these oils must be understood; only thorough tests can clarify the relation between toxicity and chemical composition, particularly with respect to selective action on different plant species.

The research described in this paper is a preliminary survey and does not attempt a detailed treatment subject to statistical analysis. Presentation of data has been organized on a topic basis to center around oil types rather than crops, weeds, or weed-control methods. Later papers, of a more popular type, will describe the more practical aspects of the use of oils in weed control. These will stress crops, weeds, and control methods.

\section{COMPOSITION OF OILS}

Classification of Oils. Oils may be classified in many ways. Naturally occurring oils of prehistoric origin are petroleum, shale oil, and gas-drip oil. These may find their way into the herbicide field in practically their natural condition; various fractions are commonly used; and altered oils (produced by destructive distillation, cracking, or catalytic synthesis) may be employed.

Petroleum is largely composed of the chemical compounds collectively named hydrocarbons, together with a few other organic compounds containing oxygen, sulfur, and nitrogen. Refined petroleum products, isolated mainly on the basis of boiling range, are available commercially and are widely used. 
The less refined of these are stove oil, Diesel fuel, and smudge-pot oil; and the more refined are gasoline, kerosene, cleaner's naphtha, commercial solvents, and lubricating oils. This report considers some chemical properties of those types of compounds that are found in petroleum or produced from it. Their chemical structure is briefly described for those unfamiliar with oil chemistry.

Hydrocarbons are compounds of carbon and hydrogen, combined, in their simpler forms, as indicated by the following formulas :<smiles>C</smiles>

or $\mathrm{CH}_{4}$

Methane<smiles>CCCC</smiles>

$\mathrm{CH}_{3}-\mathrm{CH}_{2}-\mathrm{CH}_{2}-\mathrm{CH}_{3}$

Butane<smiles>C/C=C\C</smiles><smiles>CC=CC</smiles>

Butene-2

The carbon and hydrogen atoms are joined by one or more chemical bonds (each indicated by a dash), dispersed in conformity with the tetravalent character of carbon. Although the examples given above are simple in structure, the carbon chain could be extended to many atoms ; side chains of carbon atoms could be attached at many points; the chain could be formulated into ring structures (usually limited to 5 or $\mathbf{6}$ carbon atoms); and double or even triple bonds might be present in many positions.

Since the number of possible hydrocarbons is extremely large, the need for classification seems obvious. Actually, it has proved difficult to isolate, from petroleum, individual hydrocarbons of more than 6 carbon atoms. The explanation is that with increasing chain length of the compound, the number of possible atomic arrangements increases tremendously, but the difference between boiling points rapidly decreases. Boiling range, therefore, is widely used for an approximate characterization of petroleum fractions, whereas chemical criteria are applied whenever a more exact classification is desired.

Saturated Hydrocarbons. Most of the hydrocarbons in petroleum belong to the saturated paraffins, so called because their carbon atoms are singly bonded. These have the general formula $\mathrm{C}_{n} \mathrm{H}_{2 n+2}$, where the subscript designates the number of atoms per molecule, and $n$ is any integer. Two of the simpler members of the series-methane, $\mathrm{CH}_{4}$, and butane, $\mathrm{C}_{4} \mathrm{H}_{10}$-are shown above. Separation of these saturated hydrocarbons on the basis of boiling range is common. Compounds containing 1 to 4 carbon atoms make up the gaseous hydrocarbons and are the main constituents of natural gas. The 5- to 7-carbon hydrocarbons have boiling points varying from $70^{\circ}$ to $210^{\circ} \mathrm{F}$ approximately and are marketed under the name of ligroin or petroleum ether. Succeeding groups include (1) the natural, straight-run gasoline fraction, compounds having 6 or 7 to 12 carbon atoms and a boiling range from $110^{\circ}$ to $390^{\circ} \mathrm{F} ;(2)$ the kerosene fraction, having 12 to 15 carbon atoms and boiling from $390^{\circ}$ to $525^{\circ} \mathrm{F}$; (3) the gas oil fraction having 15 to 18 carbons and boiling from $480^{\circ}$ to $570^{\circ} \mathrm{F}$. Stove oil has a boiling range of $330^{\circ}$ to $570^{\circ} \mathrm{F}$; Diesel 
oil, $400^{\circ}$ to $700^{\circ} \mathrm{F}$. Lubricating oil, greases, vaseline, and paraffin include those compounds having 16 to 24 carbon atoms; their distillation residue is mainly a petroleum coke or asphalt tar. The lower-boiling fractions of petroleum - for example, gasoline or kerosene - are often called light oils, as compared with the higher-boiling fractions termed heavy oils. Since the basis for the above fractionation is boiling range, one can enlarge any fraction considerably by varying the limits; the figures above are approximations only. Ordinary refinery procedures for preparing such paraffinic fractions are well known, and the products are available. Further fractionation of these products made it possible to study the relation between herbicidal properties and the boiling range of petroleum hydrocarbons.

The saturated hydrocarbons $\mathrm{C}_{n} \mathrm{H}_{2^{n+2}}$ have been classified into three main groups : the normal or straight-chain compounds, illustrated by pentane; the branched-chain compounds such as isopentane; and the ring structures such as cyclopentane. Typical formulas are as follows :<smiles>CCCC</smiles><smiles>CCCCC=O</smiles>

Pentane<smiles>CCCC</smiles><smiles>CCC(C)C</smiles>

Isopentane<smiles>C1CCCCC1</smiles>

$$
\begin{gathered}
\mathrm{C}_{5} \mathrm{H}_{10} \\
\text { Cyclopentane }
\end{gathered}
$$

The ring structures, including the 6-carbon-ring compound cyclohexane, with and without side chains, are termed naphthenes in petroleum technology. The saturated hydrocarbons are, with a few exceptions, rather inactive chemically; and they are the main ingredients of highly refined petroleum products such as gasoline, kerosene, and lubricating oils. 
Unsaturated Hydrocarbons. Those hydrocarbons containing carbon-tocarbon double or triple bonds are generally termed olefinic or unsaturated compounds. Typical olefins of low boiling point are the following :<smiles>C=CC=C</smiles>

Butadiene<smiles>C=CCCCCC</smiles>

Heptene-1<smiles>C=C(C)C</smiles>

Isobutylene

These are in general more reactive than the saturated hydrocarbons ; they may be removed from petroleum fractions by treatment with concentrated sulfuric acid, a common procedure in oil refining. The unsaturated hydrocarbons in refined petroleum assumed great importance when the cracking process was introduced. By this process large, relatively nonvolatile hydrocarbon molecules are broken down thermally into smaller molecules of the volatility desired in gasoline. The amount of this fuel obtained from petroleum was thereby practically doubled. The quantities of olefins formed during cracking are considerable, and are now known to increase the octane rating of gasoline. The additional refinery processes called dehydrogenation, polymerization, and alkylation, made possible by the reactivity of olefins or alkenes, have proved valuable in the synthesis of high-octane gasolines. Hence unsaturated compounds play an important role in modern refinery procedures, and they may be found in varying amounts in different products.

Aromatic Hydrocarbons. One type of unsaturated compound differing materially, in chemical properties, from those above forms an entire series, known as the aromatics. These are generally considered as derivatives of benzene. The term aromatic was originally applied because the earliest-known compounds of this type, such as cinnamon and oil of wintergreen, have agreeable odors. The structure of benzene, $\mathrm{C}_{6} \mathrm{H}_{6}$, is commonly represented as a 6 carbon cyclic structure with alternate single and double bonds.

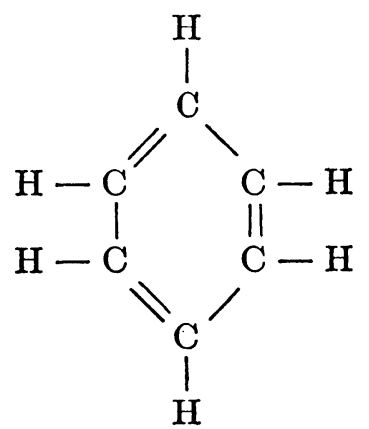


The resonance theory, developed more recently, proposes that the bonds are actually all alike; but some degree of unsaturation is indicated by their limited reactivity with certain reagents. When the hydrogen atoms of the benzene ring are substituted by carbon chains or by other cyclic structures, higherboiling aromatic compounds naturally result. A number of such compounds from gasoline and a number of naphthalenes from kerosene have been isolated. A few typical compounds are shown.

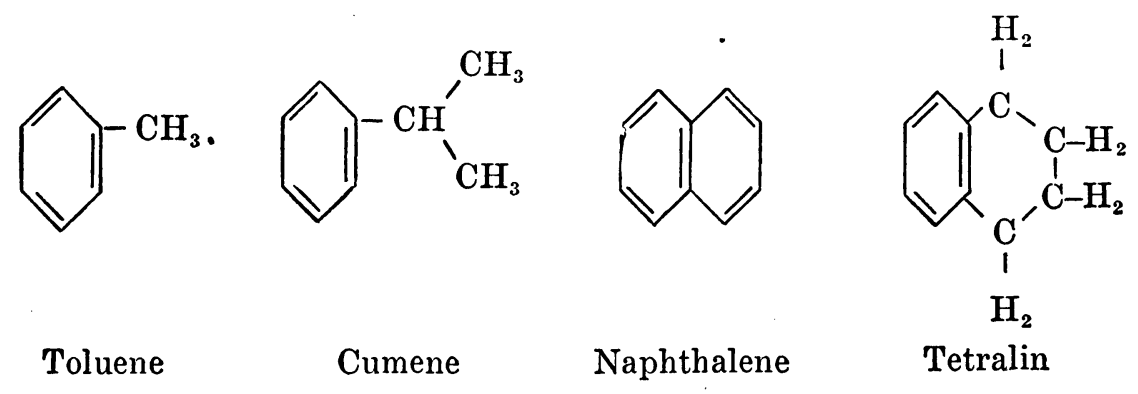

Other Compounds in Oils. Sulfur compounds occur in petroleum, usually to the extent of less than 1 per cent. They are of the paraffin type-for example, mercaptans, pentamethylene sulfides - or unsaturated ring structures such as thiophene. As a rule, these compounds are objectionable in oils. Common refinery procedures eliminate them almost completely.

Nitrogen compounds of the quinoline type are present in petroleum to less than 0.1 per cent. These nitrogen bases are readily removed by acid extraction.

Oxygen compounds ( 0.1 to 3 per cent) are usually acidic and are removed by alkaline washes. They are in general either phenols or cycloparaffinic carboxylic acids, the latter being termed, in petroleum technology, naphthenic acids. Many refined petroleum fractions, upon standing in the presence of oxygen, are subject to oxidation, with the production of peroxides and acids. Such reactions often cause the deterioration of fuel and lubrication oils, and they are commonly inhibited by the presence of naturally occurring or added antioxidants. The herbicidal properties of petroleum fractions may be appreciably altered by such oxidation, as will be reported in this paper.

Oil Refining. Refinery procedure for the treatment of petroleum has undergone and is still undergoing rapid development. From simple distillation followed by chemical treatment, refinery procedures have advanced to include cracking, re-forming, solvent extraction, isomerization, polymerization, alkylation, hydrogenation, and dehydrogenation. These processes, including both destructive fragmentation and constructive synthesis, constitute a complex field of chemical technology that makes almost innumerable products available for testing. Such products, donated by various oil companies interested in weed control, have contributed much to the studies reported here.

Besides petroleum fractions, a few additional oils may be mentioned. Gasdrip oil, a condensation product from natural gas, has been found low in herbicidal toxicity. Small lots might be fortified with dinitro compounds and made toxic enough for herbicidal purposes where other uses cannot be found. 
Nonpetroleum Oils. Oils recovered from the distillation of coal are highly aromatic and have proved very toxic to all plants. Since, however, they contain valuable compounds recoverable for solvents and organic syntheses, only small quantities are available for killing weeds. Ammonium thiocyanate, a chemical obtained from coal distillates by washing, has been tried for, weed control ; but it failed in competition with sodium chlorate. Still residues containing crude cresylic acid and similar residues have found local use; but most of this material has been needed for the preservation of timbers, posts, and ties.

As with coal, some oils from the destructive distillation of woods have been used for weed control. These have been mostly still residues from which the easily recoverable materials have been taken. One such product, a crude residue high in cresylic acid, proved extremely toxic to all plants. Since, however, it could not be easily diluted, it served only as a straight oil spray and, because of the hauling cost, could be used only near the point of production.

The popularity of fuel oils for weed control in the West is mostly due to their large-scale production and low cost. Whenever oil prices rise sufficiently, other materials (for example, chlorates, thiocyanates, sulfamates, and dinitrosubstituted phenols) become more economical for general weed control. The use of oils as selective herbicides is a different matter. For this purpose, in certain vegetable crops, there seems at present to be no substitute for light petroleum fractions. After sufficient refinement, this method of attacking weeds may well become standard practice, eliminating costly hand labor and providing a higher degree of control over all operations involved.

\section{TOXICITY OF OILS}

Though the toxicity of oils to plant foliage has long been recognized, the exact chemical mechanism is not clearly defined. Innumerable observations have been made by commercial sprayers, and for years it has been known that the crude fractions of petroleum obtained by distillation are more toxic than refined oils. Acid treatment that removed unsaturates and aromatics reduced the toxicity, and the relatively nontoxic oils used as dormant sprays on deciduous trees and as scale sprays on citrus are produced by heavy acid refining or solvent extraction. Such treatment with concentrated sulfuric acid enables one to remove the olefins and aromatics, leaving only the aliphatic and naphthene compounds. Thus Gray and de Ong $(1926)^{5}$ found the sulfonation test to be the most reliable laboratory index of toxicity; they observed that oils having an unsulfonated residue of only 50 to 60 per cent were exceedingly toxic, whereas those with an unsulfonated residue of 90 per cent or above were relatively nontoxic.

That the aromatic compounds are highly toxic has been recognized. The Tidewater and Associated Oil Company has sold a herbicidal oil high in aromatics under the name of Avon Weed Killer. This product, a residue in the refining of kerosene by the Edeleanu process, contains a large proportion of high-boiling aromatic compounds. It is extremely toxic.

That different fractions have different herbicidal properties is evident from the recommendations for their use. For instance, gasoline has been recom-

\footnotetext{
${ }^{5}$ See "Literature Cited" for citations, referred to in the text by author and date.
} 
mended for spot treatment of individual dandelion plants in lawns, whereas kerosene containing not over 4 per cent unsaturates is preferred as a selective spray for dandelions. If gasoline or any fraction higher than 4 per cent in unsaturates is used as a spray, the grass is injured.

Toxicity Types. Two types of toxicity were noted on citrus by de Ong, Knight, and Chamberlin (1927) : acute toxicity, a rapid burning of leaves by oils of low boiling point; and chronic toxicity, a slow yellowing of leaves by oils high in boiling range but fluid enough to be applied by spraying. In the herbicidal use of oils similar toxicity types have been observed. Acute toxicity, characteristic of light oils, results in rapid burning of leaves and stems. If injury is not complete within 24 to 48 hours, the plants may recover by growth of axillary buds or, with grasses, by tillering.

Chronic toxicity commonly results from oils heavy enough to give an oilsoaked appearance, and persistent enough to remain visible on the plants for several days or more. Injury symptoms of chronic toxicity usually develop slowly and may appear only after several days. They consist of a yellow blotching of leaves with slow death. Also in evidence is killing of the inner leaves of grasses. Growth is always retarded, and often secondary infection by fungi is prominent.

Killing by gasoline, engine distillate, and stove oil is largely acute; that by Diesel oil, light furnace fuel, kerosene, and light lubricating oils is chronic. The extent of injury and rapidity of killing by all oils depends upon the amount of refinement they have undergone; highly refined oils that have been largely freed of unsaturated compounds are less destructive than unrefined fractions. For further dissussion of acute and chronic toxicity see page 147.

Selectivity. Another aspect of oil toxicity is the selective action on certain plant species. As noted above, the family Umbelliferae tolerates oils; and stove oil will kill weeds with little injury to carrots, celery, parsnips, parsley, and the like. If Diesel oil is used, however, the leaves burn slowly. Evidently these crop plants can endure the acute type of injury, but chronic toxicity affects them as it does the weed species. As a trial in the field has shown, thirdstructure gasoline is even more toxic to weeds than is stove oil; it has no toxicity for carrots, and it evaporates more quickly, leaving less distasteful residue. ${ }^{6}$ When allowed to stand in the light, however, it becomes toxic and loses selectivity.

Different weed species vary in their response to oil sprays. Wild mustard, Amsinckia species, and the pigweeds are susceptible to oil toxicity. Chenopodium murale is more easily killed than C. album. Common milkweed and wild lettuce are intermediate in susceptibility. Chickweed is not only somewhat tolerant to oil, but difficult to cover thoroughly. Annual nettle is also hard to kill completely.

Malva, yellow star thistle, groundsel, pineapple weed, and purslane resiststove oil and even tolerate Diesel oil. Umbelliferae such as fennel, poison hemlock, and wild carrot are also highly tolerant.

\footnotetext{
${ }^{6}$ Since this manuscript was completed, two large oil companies have placed on the market special selective spray oils for weed control in carrots and related crops. These are lighter oils of narrower boiling range than stove oil. They have the advantage of gasoline and lack its hazards.
} 


\section{LABORATORY AND GREENHOUSE METHODS}

With the foregoing observational knowledge as a background and with many questions on the nature of oil toxicity as a stimulus, experiments were initiated aiming, first, to elucidate the chemical mechanics of the response of plants to oil sprays; second, to find new and better oil products for both selective and general weed spraying. Greenhouse plants growing in 12-inch pots and in no. 10 cans were used for toxicity tests, spraying being accomplished with a sprayer ${ }^{7}$ while the plants in a pot or can are rotated on a motor-driven turntable.

After being sprayed, the cultures were returned to the greenhouse benches. Readings were made periodically to determine the extent of injury. Acute injury was usually apparent within a few hours ; within 24 hours after spraying estimates of injury were made in order to measure the inception of this type of toxicity.

The early experiments were observed for relatively short periods, usually a week or less, because the full significance of chronic injury was not appreciated. Later the periods of observation were lengthened; some extended for a month or more; chronic injury had usually run its course within 6 weeks.

All data on injury were visual estimates of the amount of damage caused by the sprays, as compared with unsprayed controls. Estimates of acute toxicity are quite accurate, particularly in the low and high ranges. Chronic injury in the high range can be accurately estimated; in the low range plants are often retarded in growth with little visible killing of tissue. This effect is difficult to evaluate, and probably all estimates on this type of damage are low. Such retardation of growth is of little importance where complete control by a general contact spray is sought; in selective spraying, however, it may be highly important; for it allows the crop plants to outgrow and shade weeds to such an extent that the weeds offer little competition. This would be particularly true of wild oats in a flax crop.

Estimates of 100 per cent toxicity indicate that all foliage has been killed. When later readings drop in value, regrowth from axillary buds has taken place. Injury of 100 per cent on annual grasses usually indicates complete killing. On Chenopodium species, carrots, and some other plants, sprouting from axillary buds commonly occurred.

In the early experiments mixed cultures of plants were used, often consisting of one crop plant plus one or more weed species. Later it proved more satisfactory to grow pure plant cultures and to use two or more species in each test, the particular species being determined by the nature of the test.

Other problems were encountered: the need for a nontoxic diluent to use in varying the dosage of the more toxic materials; the question of volume dosage as related to size of plant and extent of wetting; the proper age and development of the different plants, particularly with respect to selective action; and the ever-present difficulties of controlling light, temperature, humidity, and so forth, under greenhouse conditions.

The problem of a nontoxic diluent has not been solved. Odorless kerosene, a heavy isoparaffin, and normal cetane have been tried; all were nontoxic on

\footnotetext{
${ }^{7}$ The De Vilbiss atomizer no. 261 has proved suitable.
} 
carrots, but even the cetane produced physiological disturbances on barley. Volume dosage was standardized by trial and error on plants of different sizes and, unless otherwise noted, consisted of the amount required to thoroughly wet the foliage of the plants. Variability in such factors as plant age, light, temperature, and humidity was largely eliminated by growing enough plants so that a complete set of oil fractions could be tested simultaneously. Since there was no possibility of accurately controlling the greenhouse environment, experiments conducted at different times of the year are not strictly comparable, and some erratic results undoubtedly were due to such differences, particularly in temperature.

\section{OIL FRACTIONS}

The testing of the herbicidal properties of oil fractions developed from some practical problems posed by carrot growers who were using stove oil as a selective spray. They asked, "Is stove oil the best fraction to use for carrot

TABLE 1

Specirications* on Stove-Oil Samples

\begin{tabular}{|c|c|c|c|c|c|c|c|c|c|c|c|c|}
\hline \multirow[b]{2}{*}{ Source of oil } & \multirow[b]{2}{*}{$\begin{array}{c}\text { Initial } \\
\text { b.p., } \\
\text { F }\end{array}$} & \multicolumn{3}{|c|}{ Temperature, $^{\circ} \mathrm{F}$, at } & \multirow[b]{2}{*}{$\begin{array}{l}\text { End } \\
\text { point, } \\
\text { o }\end{array}$} & \multirow[b]{2}{*}{$\begin{array}{l}\text { Grav- } \\
\text { ity, } \\
\text { 'A.P.I. }\end{array}$} & \multirow{2}{*}{$\begin{array}{l}\text { Vis- } \\
\text { cosity, } \\
\text { Say- } \\
\text { bolt, } \\
\text { sec. }\end{array}$} & \multirow{2}{*}{$\begin{array}{l}\text { Flash } \\
\text { point, } \\
\text { P.M. } \\
\text { c.c.. } \\
\text { F. }\end{array}$} & \multirow[b]{2}{*}{$\begin{array}{l}\text { Pour } \\
\text { point, } \\
\stackrel{F}{ }\end{array}$} & \multirow[b]{2}{*}{\begin{tabular}{|} 
Sulfur, \\
per \\
cent
\end{tabular}} & \multirow[b]{2}{*}{$\begin{array}{c}\text { Ash, } \\
\text { per } \\
\text { cent }\end{array}$} & \multirow[b]{2}{*}{$\underset{+}{\text { B.S.W }}$} \\
\hline & & $\begin{array}{c}10 \text { per } \\
\text { cent } \\
\text { recov- } \\
\text { ery }\end{array}$ & $\begin{array}{c}50 \text { per } \\
\text { cent } \\
\text { recov- } \\
\text { ery }\end{array}$ & $\begin{array}{c}90 \text { per } \\
\text { cent } \\
\text { recov- } \\
\text { ery }\end{array}$ & & & & & & & & \\
\hline Company A.. & $\begin{array}{l}340- \\
382\end{array}$ & $\cdots$ & $\ldots$ & $\ldots$ & $\begin{array}{r}552- \\
558\end{array}$ & $\begin{array}{r}37.6- \\
38.5\end{array}$ & ${ }_{33}^{31-}$ & $\begin{array}{r}134- \\
140\end{array}$ & $0-20$ & $\begin{array}{r}0.13- \\
0.68\end{array}$ & & $\cdots$ \\
\hline Company B $¥ \ldots$ & 345 & 390 & 445 & 500 & 572 & 38.5 & 32.5 & 136 & -25 & 0.18 & 0.01 & 0 \\
\hline Company C..... & $\ldots$ & 390 & 480 & $\ldots$ & $\cdots$ & 38.6 & $\ldots$ & 138 & $\begin{array}{c}\text { Below } \\
0\end{array}$ & 0.21 & $\cdots$ & $\cdots$ \\
\hline Company D§.. & 335 & 390 & $\ldots$ & 515 & 565 & 38.7 & 32 & 134 & $\begin{array}{c}\text { Below } \\
0\end{array}$ & $\begin{array}{c}\text { Below } \\
0.5\end{array}$ & Trace & Trace \\
\hline
\end{tabular}

* These specifications were supplied by the companies providing the samples.

+ Sediment and water.

† Color 1+; color not stated for other oils.

Ignition quality 51 Cetane; not stated for other oils.

TABLE 2

Toxicity of Gasoline to Amsinckia, Lactuca, Poa annua, AND BARLeY, in Carrot Cultures ; * December $15,1943 \dagger$

\begin{tabular}{|c|c|c|c|c|c|c|c|c|c|c|c|c|c|c|c|c|}
\hline \multirow{3}{*}{$\begin{array}{l}\text { Amount of gasoline } \\
\text { applied per culture }\end{array}$} & \multicolumn{16}{|c|}{ Injury to Amsinckia (A), Lactuca (L), Poa annua (P), and barley (B), in per cent } \\
\hline & \multicolumn{4}{|c|}{1 day } & \multicolumn{4}{|c|}{2 days } & \multicolumn{4}{|c|}{3 days } & \multicolumn{4}{|c|}{5 days } \\
\hline & $\mathbf{A}$ & $\mathbf{L}$ & $\mathbf{P}$ & B & A & $\mathbf{L}$ & $\mathbf{P}$ & $\mathbf{B}$ & A & $\mathbf{L}$ & $\mathbf{P}$ & B & $\mathbf{A}$ & $\mathbf{L}$ & $\mathbf{P}$ & B \\
\hline $3 \mathrm{ml}$. & 50 & 20 & 60 & 15 & 60 & 40 & 75 & 20 & 75 & 60 & 75 & 20 & 90 & 75 & 100 & 25 \\
\hline $6 \mathrm{ml} .$. & 75 & 40 & 70 & 60 & 85 & 50 & 90 & 60 & 90 & 50 & 90 & 75 & 95 & 90 & 100 & 90 \\
\hline $9 \mathrm{ml} \ldots$ & 95 & 75 & 50 & 90 & 100 & 95 & 95 & 95 & 100 & 100 & 95 & 100 & 100 & 100 & 100 & 100 \\
\hline $12 \mathrm{ml} . \ldots \ldots \ldots \ldots \ldots$ & 100 & 80 & 75 & 95 & 100 & 95 & 95 & 95 & 100 & 100 & 100 & 100 & 100 & 100 & 100 & 100 \\
\hline $15 \mathrm{ml} \ldots \ldots \ldots \ldots \ldots$ & 100 & 100 & 100 & 100 & 100 & 100 & 100 & 100 & 100 & 100 & 100 & 100 & 100 & 100 & 100 & 100 \\
\hline
\end{tabular}

* No injury to carrots was evident at volume rates as high as $24 \mathrm{ml}$ per culture.

$\dagger$ Date of application. 
TABLE 3

Toxictry of Stove Oil to Carrots, Wheds, * and Grass ; JANUARY 30, 1943

\begin{tabular}{|c|c|c|c|c|c|c|c|c|c|}
\hline \multirow{3}{*}{$\begin{array}{l}\text { Amount of } \\
\text { stove oil } \\
\text { applied } \\
\text { per culture }\end{array}$} & \multicolumn{9}{|c|}{ Injury to carrots $(C)$, weeds $(W)$, and grass $(G)$, in per cent } \\
\hline & \multicolumn{3}{|c|}{1 day } & \multicolumn{3}{|c|}{3 days } & \multicolumn{3}{|c|}{6 days } \\
\hline & C & $\mathbf{W}$ & G & $\mathbf{C}$ & W & G & $\mathrm{C}$ & $\mathbf{W}$ & G \\
\hline $1 \mathrm{ml} \ldots \ldots \ldots \ldots$ & 0 & 10 & 0 & 0 & 15 & 10 & 0 & 20 & 10 \\
\hline $2 \mathrm{ml} \ldots \ldots \ldots \ldots$ & 0 & 10 & 50 & 0 & 15 & 50 & 0 & 20 & 50 \\
\hline $3 \mathrm{ml} \ldots . .$. & 0 & 75 & 90 & 0 & 75 & 90 & 0 & 75 & 90 \\
\hline $4 \mathrm{ml} \ldots \ldots \ldots \ldots$ & 0 & 90 & 90 & 0 & 90 & 95 & 0 & 90 & 95 \\
\hline $5 \mathrm{ml} \ldots \ldots \ldots \ldots$ & 5 & 90 & 90 & 5 & 90 & 95 & 5 & 95 & 100 \\
\hline $6 \mathrm{ml} \ldots \ldots \ldots \ldots$ & 5 & 90 & 90 & 10 & 95 & 95 & 10 & 95 & 100 \\
\hline
\end{tabular}

- The weeds referred to here were Brassica, Amsinckia, and Lactuca species.

TABLE 4

Toxicity of Gasoline, Stove Oil, and Diesel Oil to Weeds, * Grass, Carrots, and Flax; February 28, 1944

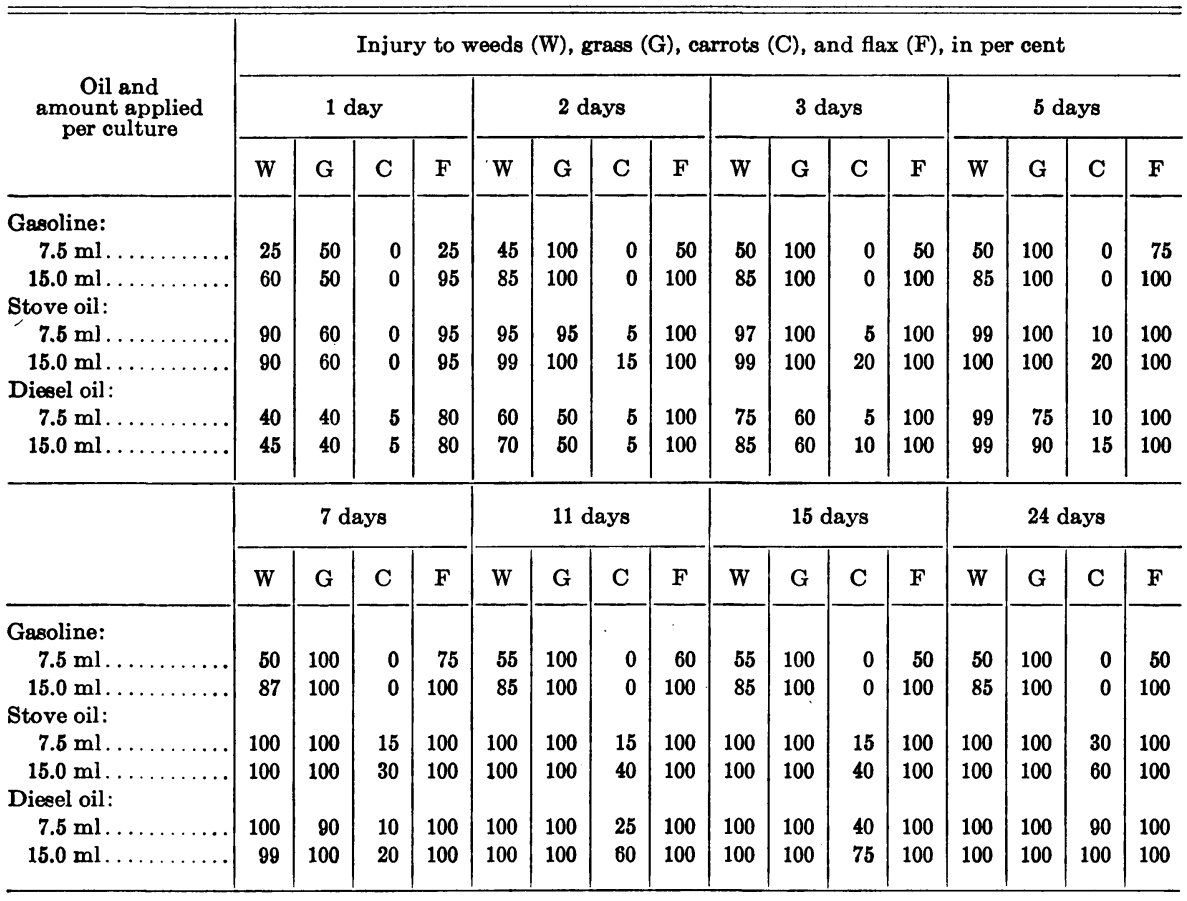

* Weeds referred to here were Brassica, Amsinckia, and Lactuca species. 


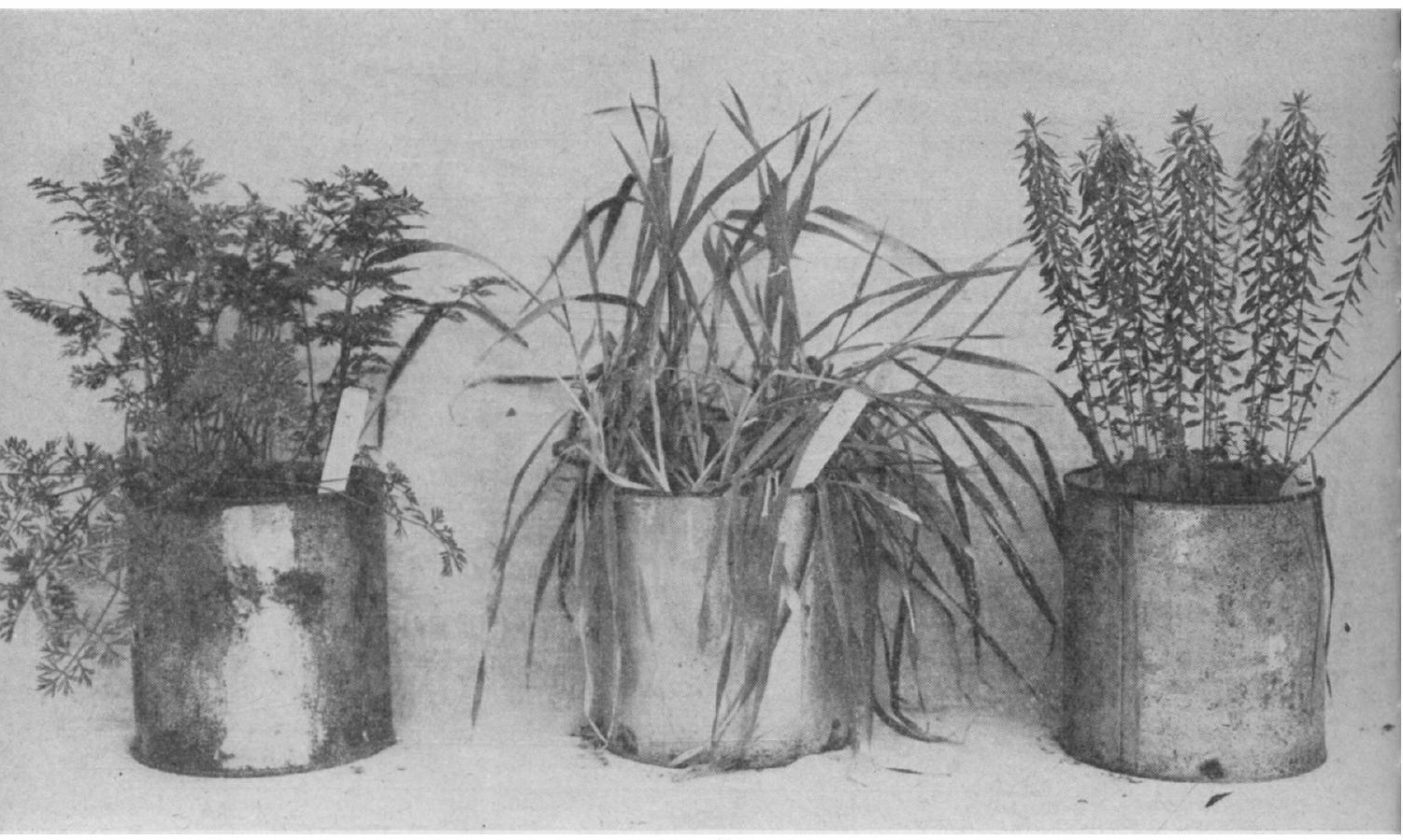

$\boldsymbol{A}$

Fig. 1.-Effects of oil sprays on plant cultures. $A$, Untreated check; left, carrots; center, barley; and right, flax. $B$, Similar cultures sprayed with stove oil. The flax and barley were killed; the carrots were not injured.

Comparison of Stove Oil, Gasoline, and Diesel Oil. One early experiment compared four stove-oil samples obtained from different companies. Table 1 gives the common specifications on these oils. T'ested on cultures of carrots, mustard, fiddleneck, and annual bluegrass, these four samples showed no significant differences. As shown in table 1, the gravity ratings of the samples were almost identical. Recently stove oil with an A.P.I. gravity rating of $34.7^{\circ}$ proved toxic to carrots in the field. This fact suggested that an oil only slightly heavier than stove oil might contain compounds injurious to carrots.

In contrast to this result, gasoline proved harmless to carrots but highly toxic to weeds. A sample of white gasoline was used in the tests, and volumes ranging from 3 to $24 \mathrm{ml}$ per culture were applied. Even the highest rate (about four times the usual volume for such cultures) proved nontoxic to the carrots. Table 2 gives the results on barley and on three weed species.

In a volume-rate test of stove oil on carrots, mixed weeds, and grass, when as much as 5 and $6 \mathrm{ml}$ of this material was used per culture, the carrots suffered slightly. Judging from table 3, dosage might be critical in field application of stove oil. This hypothesis is confirmed by reports of occasional injury to carrots when heavy dosages are used in commercial application. 


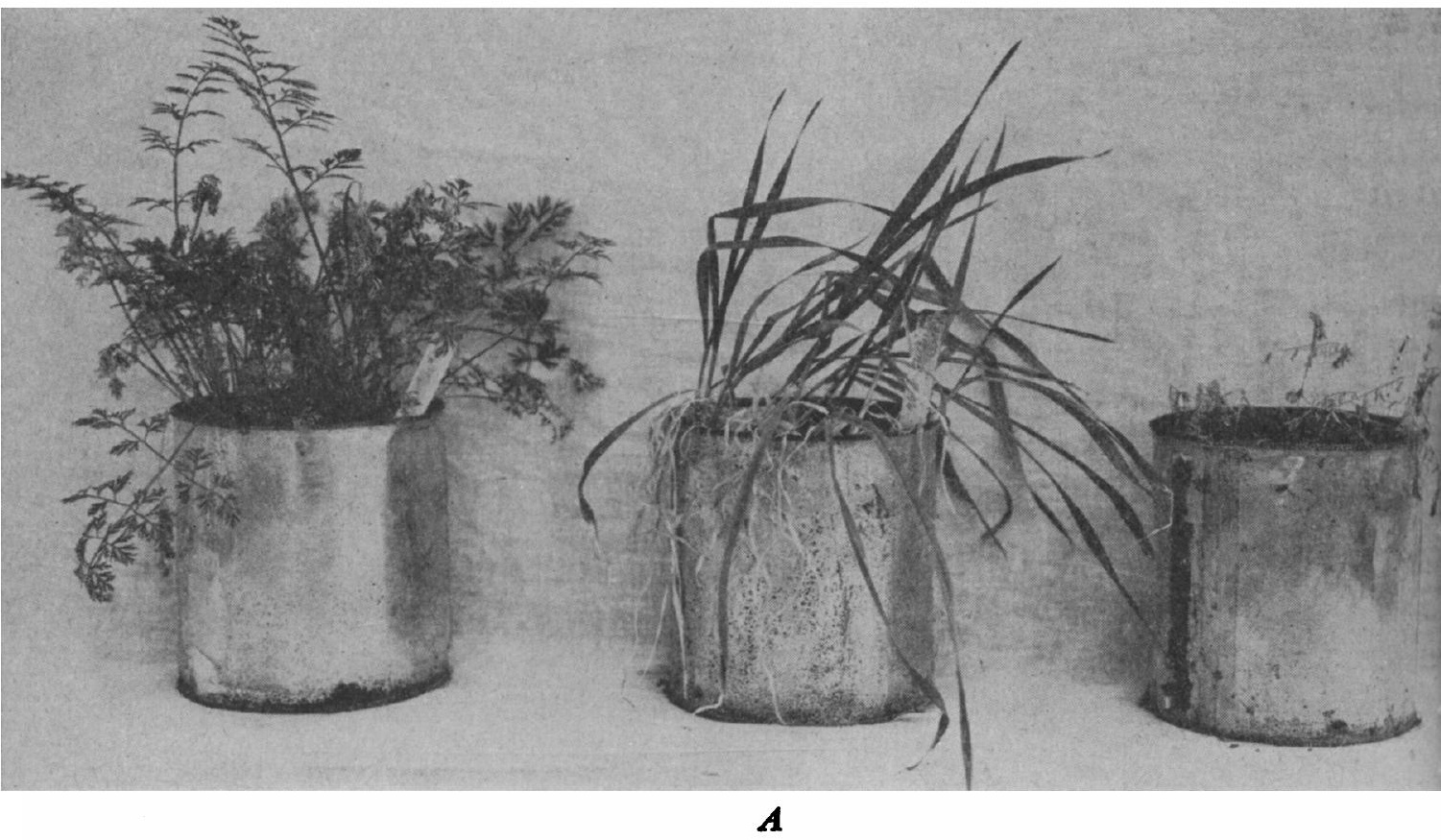

Fig. 2.-A, Carrot, barley, and flax cultures sprayed with white gasoline. Injury was very rapid but under the high temperature conditions of the experiment the gasoline evaporated so rapidly that the barley received only a partial contact injury. The flax was killed. B, Similar cultures sprayed with a fresh sample of kerosene. The barley succumbed to the slow chronic injury; carrots and flax were uninjured. Similar results followed spraying with the unsulfonated residue of stove oil. as they wet the plants. This volatility determines exposure time. The difference between acute and chronic toxicity may well relate, at least partly, to the difference in time of contact of the toxicants.

Carrots, apparently, tolerate the acute toxicants of oil fractions, but are susceptible to the chronic toxicants of fractions with boiling ranges above $424^{\circ} \mathrm{F}$.

Toxicity of Straight-Run and Cracked Gasolines. The results of experiments reported in tables 2 and 4 show that gasoline is toxic to plants and has highly selective properties. Two pertinent questions arise. First, by eliminating the highly inflammable light end of the normal gasoline fraction, can one produce an oil that will surpass stove oil in selectivity and in absence of residue? Second, what is the nature of gasoline toxicity, and what other roles may gasoline play in weed control?

Because these and other questions were frequently recurring, studies on gasoline were made. Table 5 presents data collected over 7 days on the toxicity 
TABLE 5 .

Toxicity of Oil Fractions to Weeds, * Grass, and Carrots ; SEPTEMBER 23, 1943

\begin{tabular}{|c|c|c|c|c|c|c|c|c|c|}
\hline \multirow{3}{*}{$\begin{array}{l}\text { Oil, fraction no., } \\
\text { and } \\
\text { boiling range in }{ }^{\circ} \mathrm{F}\end{array}$} & \multicolumn{9}{|c|}{ Injury to weeds $(W)$, grass $(G)$, and carrots $(C)$, in per cent } \\
\hline & \multicolumn{3}{|c|}{2 days } & \multicolumn{3}{|c|}{4 days } & \multicolumn{3}{|c|}{7 days } \\
\hline & $\mathbf{W}$ & G & $\mathrm{C}$ & W & G & $\mathrm{C}$ & W & G & $\mathrm{C}$ \\
\hline \multicolumn{10}{|l|}{ Gasoline: } \\
\hline No. $1,100^{\circ}-227^{\circ}$ & 60 & 90 & 0 & 70 & 90 & 0 & 75 & 90 & 0 \\
\hline No. $2,227^{\circ}-293^{\circ}$. & 90 & 90 & 0 & 99 & 90 & 0 & 99 & 95 & 0 \\
\hline No. $3,293^{\circ}-338^{\circ}$. & 95 & 95 & 0 & 100 & 100 & 0 & 100 & 100 & 0 \\
\hline No. $4,338^{\circ}-420^{\circ}$. & 100 & 95 & 0 & 100 & 100 & 0 & 100 & 100 & 0 \\
\hline \multicolumn{10}{|l|}{ Stove oil: } \\
\hline No. $1,330^{\circ}-392^{\circ}$. & 90 & 90 & 0 & 100 & 90 & 0 & 100 & 98 & 0 \\
\hline No. $2,392^{\circ}-424^{\circ}$. & 80 & 95 & 0 & 100 & 95 & 0 & 100 & 100 & 0 \\
\hline No. $3,424^{\circ}-473^{\circ}$. & 75 & 90 & 0 & 95 & 95 & $\mathbf{5}$ & 100 & 100 & 10 \\
\hline No. $4,473^{\circ}-\ldots$. & 60 & 80 & 5 & 90 & 90 & 20 & 100 & 95 & 50 \\
\hline \multicolumn{10}{|l|}{ Diesel oil: } \\
\hline No. $1,392^{\circ}-487^{\circ}$. & 75 & 85 & 0 & 95 & 98 & 0 & 100 & 100 & 0 \\
\hline No. $2,487^{\circ}-545^{\circ} \ldots$ & 70 & 75 & 0 & 95 & 90 & 5 & 100 & 100 & 10 \\
\hline No. $3,545^{\circ}-590^{\circ} \ldots \ldots \ldots$ & 60 & 60 & 10 & 90 & 100 & 20 & 100 & 100 & 50 \\
\hline No. $4,590^{\circ}-\ldots \ldots \ldots$. & 40 & 35 & 20 & 80 & 100 & 50 & 100 & 100 & 100 \\
\hline
\end{tabular}

* Weeds referred to here were Brassica, Amsinckia, and Lactuca species.

TABLE 6

Toxicity of Fractional Distillates of White Gasoline to Onions and Grass; MAY 5, 1944

\begin{tabular}{|c|c|c|c|c|c|c|c|c|c|c|}
\hline \multirow{3}{*}{$\begin{array}{l}\text { White gasoline fraction } \\
\text { no. and amounts of gas } \\
\text { and diluent (isoparaffin) } \\
\text { applied per culture }\end{array}$} & \multicolumn{10}{|c|}{ Injury to onions $(0)$ and grass $(G)$, in per cent } \\
\hline & \multicolumn{2}{|c|}{$1 \mathrm{day}$} & \multicolumn{2}{|c|}{3 days } & \multicolumn{2}{|c|}{5 days } & \multicolumn{2}{|c|}{10 days } & \multicolumn{2}{|c|}{15 days } \\
\hline & O & G & O & G & $\mathrm{O}$ & G & $\mathrm{O}$ & G & $\mathbf{0}$ & G \\
\hline Fraction no. 1: & & & & & & & & & & \\
\hline $12 \mathrm{ml}$ gas, $0 \mathrm{ml} \mathrm{IP...}$ & 20 & 90 & 10 & 90 & $\mathbf{5}$ & 90 & 0 & 90 & 0 & 95 \\
\hline $6 \mathrm{ml}$ gas, $6 \mathrm{ml} \mathrm{IP} \ldots \ldots$ & 0 & 10 & 0 & 10 & 0 & 10 & 0 & 20 & 0 & 25 \\
\hline Fraction no. 2: & & & & & & & & & & \\
\hline $12 \mathrm{ml}$ gas, $0 \mathrm{ml} \mathrm{IP...}$ & 30 & 90 & 20 & 90 & 10 & 95 & 0 & 100 & 0 & 100 \\
\hline $6 \mathrm{ml}$ gas, $6 \mathrm{ml} \mathrm{IP.....}$ & $\mathbf{0}$ & 10 & 0 & 15 & 0 & 15 & 0 & 25 & 0 & 40 \\
\hline Fraction no. 3 : & & & & & & & & & & \\
\hline $12 \mathrm{ml}$ gas, $0 \mathrm{ml} \mathrm{IP} \ldots .$. & 50 & 95 & 50 & 100 & 40 & 100 & 40 & 100 & 40 & 100 \\
\hline $6 \mathrm{ml}$ gas, $6 \mathrm{ml} \mathrm{IP....}$ & 10 & 50 & 10 & 60 & 5 & 75 & 0 & 90 & 0 & 90 \\
\hline Fraction no. 4: & & & & & & & & & & \\
\hline $12 \mathrm{ml}$ gas, $0 \mathrm{ml} \mathrm{IP} \ldots \ldots$ & 65 & 95 & 60 & 100 & 50 & 100 & 30 & 100 & 20 & 100 \\
\hline $6 \mathrm{ml}$ gas, $6 \mathrm{ml} \mathrm{IP.....}$ & 15 & 75 & 15 & 85 & 10 & 90 & 0 & 90 & 0 & 90 \\
\hline $\begin{array}{l}\text { Fraction no. } 3 \text {, refluxed } \\
\text { without air: }\end{array}$ & & & & & & & & & & \\
\hline $12 \mathrm{ml}$ gas, $0 \mathrm{ml} \mathrm{IP} \ldots \ldots$ & 50 & 95 & 50 & 95 & 50 & 95 & 40 & 100 & 40 & 100 \\
\hline $6 \mathrm{ml}$ gas, $6 \mathrm{ml} \mathrm{IP.....}$ & 0 & 40 & 0 & 40 & 0 & 40 & 0 & 50 & 0 & 50 \\
\hline $\begin{array}{l}\text { Fraction no. } 3 \text {, refluxed } \\
\text { with air: }\end{array}$ & & & & & & & & & & \\
\hline $12 \mathrm{ml}$ gas, $0 \mathrm{ml} \mathrm{IP} \ldots \ldots$ & 50 & 90 & 30 & 90 & 20 & 95 & 0 & 100 & 0 & 100 \\
\hline $6 \mathrm{ml}$ gas, $6 \mathrm{ml} \mathrm{IP} \ldots \ldots$ & 0 & 25 & 0 & 30 & 0 & 50 & 0 & 60 & 0 & 90 \\
\hline $\begin{array}{l}\text { Fraction no. 4, refluxed } \\
\text { without air: }\end{array}$ & & & & & & & & & & \\
\hline $12 \mathrm{ml}$ gas, $0 \mathrm{ml} \mathrm{IP....}$ & 50 & 90 & 40 & 90 & 30 & 95 & 20 & 100 & 10 & 100 \\
\hline $6 \mathrm{ml}$ gas, $6 \mathrm{ml} \mathrm{IP} . \ldots$ & 10 & 40 & 10 & 40 & 0 & 50 & 0 & 50 & 0 & 75 \\
\hline $\begin{array}{l}\text { Fraction no. } 4 \text {, refluxed } \\
\text { with air: }\end{array}$ & & & & & & & & & & \\
\hline $12 \mathrm{ml}$ gas, $0 \mathrm{ml} \mathrm{IP....}$ & 70 & 90 & 60 & 90 & 50 & 95 & 40 & 100 & 40 & 100 \\
\hline $6 \mathrm{ml}$ gas, $6 \mathrm{ml} \mathrm{IP....}$ & 0 & 75 & 0 & 75 & 0 & 75 & $\mathbf{0}$ & 75 & $\mathbf{0}$ & 90 \\
\hline
\end{tabular}


Because most gasolines contain hydrocarbons produced by cracking, it seems desirable to compare the toxicities of cracked and straight-run samples. Two fresh samples received in April, 1944, had the following properties:

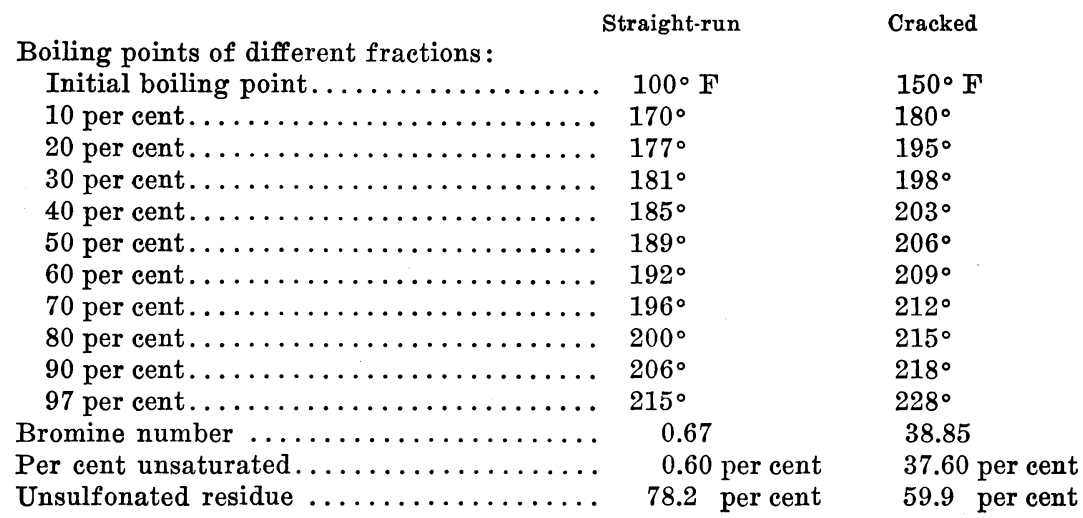

According to these data, the cracked gasoline has a much higher degree of unsaturation and therefore should be more toxic (see p. 108 to 112). Table 7 shows the results of a preliminary test on wild mustard, run at three concentrations.

TABLE 7

Toxicity of Straight-Run and Cracked Gasoline on Brassica; MAY 5, 1944

\begin{tabular}{|c|c|c|c|c|}
\hline \multirow{2}{*}{$\begin{array}{l}\text { Type of gasoline and } \\
\text { amounts of gas and diluent } \\
\text { (isoparaffin) applied } \\
\text { per culture }\end{array}$} & \multicolumn{4}{|c|}{ Injury to Brassica, in per cent } \\
\hline & 1 day & 2 days & 4 days & 7 days \\
\hline \multicolumn{5}{|l|}{ Straight-run gasoline: } \\
\hline $71 / 2 \mathrm{ml}$ gas, $21 / 2 \mathrm{ml} \mathrm{IP......}$ & 20 & 20 & 20 & 20 \\
\hline $5 \mathrm{ml}$ gas, $5 . \mathrm{ml} \mathrm{IP.........}$ & 0 & 0 & 0 & $\mathbf{5}$ \\
\hline \multicolumn{5}{|l|}{ Cracked gasoline: } \\
\hline $10 \mathrm{ml}$ gas, $0 \mathrm{ml} \mathrm{IP. \ldots .....}$ & 95 & 95 & 95 & 100 \\
\hline $71 / 2 \mathrm{ml}$ gas, $21 / 2 \mathrm{ml}$ IP.... & 75 & 85 & 90 & 90 \\
\hline $5 \mathrm{ml}$ gas, $5 \mathrm{ml} \mathrm{IP........}$ & 20 & 20 & 30 & 60 \\
\hline
\end{tabular}

These results confirm the prediction that the cracked gasoline would be more toxic than the straight-run sample. The shift in toxicity with time is also greater-a fact indicating a higher content of chronic toxicants.

Table 8 presents data from tests on mustard, fiddleneck, and carrots; straight-run and cracked gasolines were used, and the first fraction of stove oil is added for comparison. Here, again, the cracked gasoline is most toxic ; in fact, it damaged carrots considerably. The sample of straight-run gasoline at $15 \mathrm{ml}$ per culture also injured carrots, whereas the stove-oil fraction was noninjurious. These results contrast with the data in table 2 (p. 86) on tests in which $24 \mathrm{ml}$ of gasoline failed to cause injury. 
Table 9 gives data for the same three fractions on grass and flax. Grass is the most seriously injured, and cracked gasoline is the most toxic fraction. Flax, which is intermediate in tolerance of oil toxicity, was severely injured by these fractions - a fact indicating that the acute toxicants which they carry are not selective on this crop.

TABLE 8

Toxicity of Straight-Run and Cracked Gasolines and Stove Oil to Weeds* AND CARrots ; November 3, 1944

\begin{tabular}{|c|c|c|c|c|c|c|c|c|c|c|c|c|}
\hline \multirow{3}{*}{$\begin{array}{l}\text { Oil fraction } \\
\text { and amount applied } \\
\text { per culture }\end{array}$} & \multicolumn{12}{|c|}{ Injury to weeds (W) and carrots (C), in per cent } \\
\hline & \multicolumn{2}{|c|}{1 day } & \multicolumn{2}{|c|}{2 days } & \multicolumn{2}{|c|}{3 days } & \multicolumn{2}{|c|}{4 days } & \multicolumn{2}{|c|}{5 days } & \multicolumn{2}{|c|}{7 days } \\
\hline & W & $\mathrm{C}$ & W & $\mathrm{C}$ & W & $\mathrm{C}$ & W & $\mathrm{C}$ & $\mathrm{W}$ & $\mathrm{C}$ & W & C \\
\hline \multicolumn{13}{|l|}{$\begin{array}{c}\text { Straight-run } \\
\text { gasoline: }\end{array}$} \\
\hline $3 \mathrm{ml} \ldots \ldots \ldots \ldots$ & 60 & 0 & 75 & 0 & 85 & 0 & 90 & 0 & 90 & 0 & 90 & 0 \\
\hline $4 \mathrm{ml} \ldots$. & 75 & 0 & 85 & $\mathbf{0}$ & 95 & 0 & 95 & 0 & 95 & 0 & 100 & 0 \\
\hline $5 \mathrm{ml} \ldots$ & 90 & 0 & 95 & $\mathbf{0}$ & 98 & $\mathbf{0}$ & 99 & $\mathbf{0}$ & 99 & 0 & 100 & 0 \\
\hline $6 \mathrm{ml} \ldots .$. & 90 & 0 & 95 & $\mathbf{0}$ & 99 & 0 & 100 & 0 & 100 & 0 & 100 & 0 \\
\hline $8 \mathrm{ml} \ldots$. & 95 & 0 & 99 & 0 & 100 & 0 & 100 & 0 & 100 & 0 & 100 & 0 \\
\hline $10 \mathrm{ml} \ldots .$. & 95 & 0 & 99 & 0 & 100 & 0 & 100 & 0 & 100 & 0 & 100 & 0 \\
\hline $12 \mathrm{ml} . \ldots \ldots \ldots \ldots$ & 98 & $\mathbf{0}$ & 99 & 0 & 100 & 0 & 100 & 0 & 100 & 0 & 100 & 0 \\
\hline $15 \mathrm{ml} \ldots \ldots \ldots \ldots$ & 99 & 0 & 99 & 0 & 100 & 10 & 100 & 10 & 100 & 10 & 100 & 10 \\
\hline \multicolumn{13}{|l|}{ Cracked gasoline: } \\
\hline $3 \mathrm{ml} \ldots \ldots \ldots$ & 75 & 0 & 90 & 0 & 98 & 0 & 100 & 0 & 100 & 0 & 100 & 0 \\
\hline $4 \mathrm{ml} \ldots \ldots \ldots \ldots$ & 85 & 0 & 95 & 0 & 99 & 0 & 100 & 0 & 100 & 0 & 100 & 0 \\
\hline $5 \mathrm{ml} \ldots \ldots \ldots \ldots$ & 95 & 0 & 98 & 0 & 100 & 0 & 100 & $\mathbf{0}$ & 100 & 0 & 100 & 0 \\
\hline $6 \mathrm{ml} \ldots \ldots \ldots \ldots$ & 95 & 0 & 99 & 0 & 100 & 0 & 100 & 0 & 100 & 0 & 100 & 0 \\
\hline $8 \mathrm{ml} \ldots \ldots \ldots \ldots$ & 97 & 0 & 99 & 0 & 100 & 0 & 100 & 0 & 100 & 0 & 100 & 0 \\
\hline $10 \mathrm{ml} \ldots \ldots \ldots \ldots$ & 99 & 0 & 100 & 10 & 100 & 10 & 100 & 10 & 100 & 10 & 100 & 5 \\
\hline $12 \mathrm{ml} \ldots \ldots \ldots \ldots$ & 99 & 0 & 100 & 25 & 100 & 25 & 100 & 25 & 100 & 25 & 100 & 15 \\
\hline $15 \mathrm{ml} \ldots \ldots \ldots \ldots$ & 99 & 0 & 100 & 40 & 100 & 40 & 100 & 40 & 100 & 40 & 100 & 30 \\
\hline \multicolumn{13}{|l|}{ Stove oil no. 1: } \\
\hline $3 \mathrm{ml} \ldots \ldots \ldots$ & 70 & 0 & 85 & 0 & 85 & 0 & 85 & $\mathbf{0}$ & 85 & 0 & 80 & 0 \\
\hline $4 \mathrm{ml} \ldots \ldots \ldots$ & 85 & 0 & 90 & 0 & 95 & 0 & 98 & 0 & 99 & 0 & 100 & 0 \\
\hline $5 \mathrm{ml} \ldots \ldots \ldots$ & 90 & 0 & 95 & 0 & 98 & 0 & 99 & $\mathbf{0}$ & 100 & 0 & 100 & 0 \\
\hline $6 \mathrm{ml} \ldots \ldots .$. & 95 & 0 & 98 & 0 & 100 & 0 & 100 & 0 & 100 & 0 & 100 & 0 \\
\hline $8 \mathrm{ml} \ldots \ldots$ & 98 & 0 & 99 & 0 & 100 & 0 & 100 & 0 & 100 & 0 & 100 & 0 \\
\hline $10 \mathrm{ml} \ldots$. & 99 & 0 & 100 & 0 & 100 & 0 & 100 & $\mathbf{0}$ & 100 & 0 & 100 & 0 \\
\hline $12 \mathrm{ml} \ldots \ldots \ldots \ldots$ & 99 & 0 & 100 & 0 & 100 & 0 & 100 & 0 & 100 & 0 & 100 & 0 \\
\hline $15 \mathrm{ml} \ldots \ldots \ldots \ldots$ & 100 & 0 & 100 & 0 & 100 & 0 & 100 & 0 & 100 & 0 & 100 & 0 \\
\hline
\end{tabular}

* Weeds referred to here were Brassica and Amsinckia species.

Kerosene and Mineral Seal Oil. Testing of additional commercial oil fractions was carried out with a twofold objective: to find a nontoxic diluent for use in applying compounds of known toxicity; and to discover, if possible, further selectivities for use in field practice. At the outset of the oil studies, a large sample of odorless kerosene was provided as a nontoxic diluent. Probably it had been solvent-extracted (Edeleanu process) and heavily acidtreated; supposedly it was inert toward plant growth. Another, heavier fraction, called mineral seal oil, which had received similar treatment, was also suggested as a diluent. Table 10 (p. 98) presents data on tests of odorless kerosene, common kerosene, and mineral seal oil. These tests accompanied those reported, in table 4, on gasoline, stove oil, and Diesel oil. 
As table 10 shows, kerosene had a slight acute toxicity on the mixed weed cultures, but the plants grew out of this injury by the end of the 24-day period of observation. Against grass, on the other hand, there developed after about 5 days a toxicity that increased rapidly with time and that finally killed the cultures. Carrots and flax were immune to this damage. Figure $2, B$, illustrates the effects of chronic injury by kerosene.

\section{TABLE 9}

Toxicity of Straight-Run Gasoline, Cracked Gasoline, and Stove-Oil Fraction No. 1 to Grass aNd FlaX; November 3, 1944

\begin{tabular}{|c|c|c|c|c|c|c|c|c|c|c|c|c|}
\hline \multirow{3}{*}{$\begin{array}{l}\text { Oil fraction } \\
\text { and amount applied } \\
\text { per culture }\end{array}$} & \multicolumn{12}{|c|}{ Injury to grass $(G)$ and flax $(F)$, in per cent } \\
\hline & \multicolumn{2}{|c|}{1 day } & \multicolumn{2}{|c|}{2 days } & \multicolumn{2}{|c|}{3 days } & \multicolumn{2}{|c|}{4 days } & \multicolumn{2}{|c|}{5 days } & \multicolumn{2}{|c|}{7 days } \\
\hline & $\mathrm{G}$ & $\mathrm{F}$ & G & $\mathbf{F}$ & G & $\mathbf{F}$ & G & F & G & $\mathbf{F}$ & G & $\mathbf{F}$ \\
\hline \multicolumn{13}{|l|}{$\begin{array}{l}\text { Straight-run gaso- } \\
\text { line: }\end{array}$} \\
\hline $2 \mathrm{ml} \ldots \ldots \ldots \ldots$ & 60 & 40 & 95 & 60 & 100 & 60 & 100 & 60 & 100 & 60 & 100 & 60 \\
\hline $3 \mathrm{ml} \ldots \ldots \ldots \ldots$ & 60 & 40 & 95 & 90 & 95 & 90 & 99 & 90 & 100 & 90 & 100 & 90 \\
\hline $4 \mathrm{ml} \ldots \ldots \ldots \ldots \ldots$ & 75 & 60 & 100 & 95 & 100 & 100 & 100 & 100 & 100 & 99 & 100 & 99 \\
\hline $5 \mathrm{ml} \ldots \ldots \ldots \ldots \ldots$ & 90 & 80 & 100 & 95 & 100 & 95 & 100 & 99 & 100 & 100 & 100 & 100 \\
\hline $6 \mathrm{ml} \ldots \ldots \ldots \ldots$ & 95 & 90 & 100 & 98 & 100 & 100 & 100 & 100 & 100 & 100 & 100 & 100 \\
\hline $8 \mathrm{ml} \ldots \ldots \ldots \ldots$ & 95 & 95 & 100 & 98 & 100 & 100 & 100 & 100 & 100 & 100 & 100 & 100 \\
\hline \multicolumn{13}{|l|}{ Cracked gasoline: } \\
\hline $2 \mathrm{ml} \ldots \ldots \ldots \ldots$ & 75 & 50 & 90 & 75 & 100 & 75 & 100 & 75 & 100 & 75 & 100 & 85 \\
\hline $3 \mathrm{ml} \ldots \ldots \ldots \ldots \ldots$ & 90 & 80 & 100 & 95 & 100 & 98 & 100 & 98 & 100 & 99 & 100 & 99 \\
\hline $4 \mathrm{ml} \ldots \ldots \ldots$ & 95 & 90 & 100 & 98 & 100 & 100 & 100 & 100 & 100 & 100 & 100 & 100 \\
\hline $5 \mathrm{ml} \ldots \ldots \ldots \ldots \ldots$ & 100 & 100 & 100 & 100 & 100 & 100 & 100 & 100 & 100 & 100 & 100 & 100 \\
\hline $6 \mathrm{ml} \ldots \ldots \ldots \ldots$ & 100 & 100 & 100 & 100 & 100 & 100 & 100 & 100 & 100 & 100 & 100 & 100 \\
\hline $8 \mathrm{ml} \ldots \ldots \ldots \ldots$ & 100 & 100 & 100 & 100 & 100 & 100 & 100 & 100 & 100 & 100 & 100 & 100 \\
\hline \multicolumn{13}{|l|}{ Stove oil no. 1: } \\
\hline $2 \mathrm{ml} \ldots \ldots \ldots$ & 75 & 60 & 100 & 90 & 100 & 90 & 100 & 90 & 100 & 90 & 100 & 90 \\
\hline $3 \mathrm{ml} \ldots \ldots \ldots$ & 75 & 75 & 100 & 90 & 100 & 90 & 100 & 90 & 100 & 90 & 100 & 90 \\
\hline $4 \mathrm{ml} \ldots \ldots$. & 85 & 80 & 100 & 95 & 100 & 95 & 100 & 95 & 100 & 98 & 100 & 98 \\
\hline $5 \mathrm{ml} \ldots$ & 95 & 90 & 100 & 95 & 100 & 95 & 100 & 98 & 100 & 98 & 100 & 99 \\
\hline $6 \mathrm{ml} \ldots \ldots$ & 98 & 95 & 100 & 95 & 100 & 98 & 100 & 99 & 100 & 100 & 100 & 100 \\
\hline $8 \mathrm{ml} \ldots \ldots \ldots \ldots$ & 98 & 85 & 100 & 98 & 100 & 100 & 100 & 100 & 100 & 100 & 100 & 100 \\
\hline
\end{tabular}

Odorless kerosene lacked acute toxicity, but produced chronic toxicity somewhat more rapidly on grass than did the plain kerosene; some injury was observed on the fifth day. Evidently the refining treatment did not prevent the oil from causing this type of injury.

Although mineral seal oil had no initial effect, it caused, after 5 days, a chronic injury, which increased with time and damaged all the species tested. Figure $3, A$, shows the results of spraying carrots, barley, and flax with mineral seal oil.

Kerosene having a boiling range of $350^{\circ}$ to about $470^{\circ} \mathrm{F}$ is somewhat lighter than stove oil. Furthermore, the aromatic and olefinic content is less in kerosene owing to the refining procedures ordinarily used. This latter fact may explain its lack of toxicity to carrots. In table 10, kerosene appears too toxic to serve as a diluent where grasses and mixed weeds are the test plants. Odorless kerosene is also of questionable value for this purpose. 


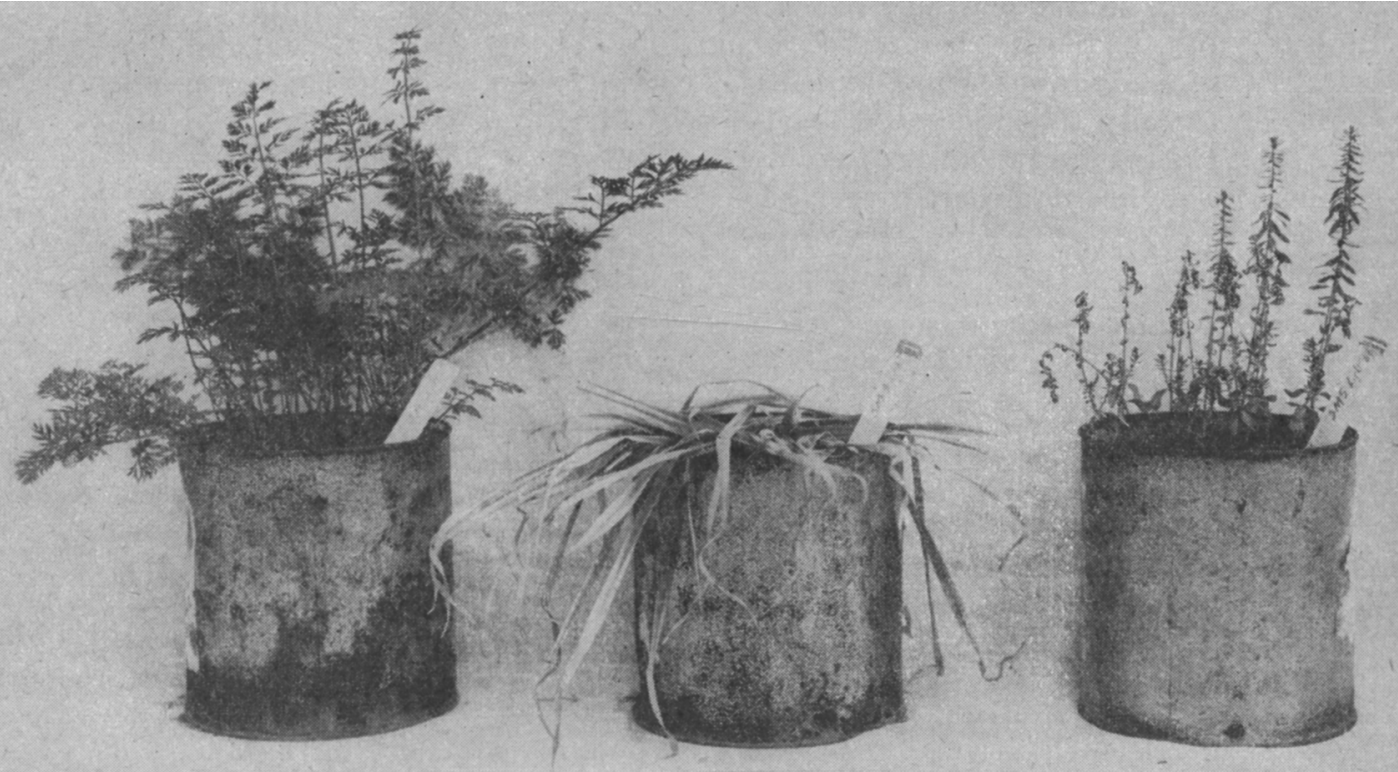

Fig. 3.- $A$, Carrot, barley, and flax cultures sprayed with mineral seal oil. The barley succumbed to chronic toxicity; the flax was partially injured; carrots were uninjured when photographed but later many of the plants died. $B$, Similar cultures sprayed with normal cetane. At this stage a clustering of the leaves of the flax due to foreshortening of the internodes is the only symptom. Later, the flax recovered and grew normally; the barley became heavily infected with mildew and growth was retarded. toxic ; but if these unsaturates are reduced in concentration by refining processes, the remaining oil becomes again nontoxic to carrots though still toxic to grass. This is the case with kerosene.

Grasses are apparently much more susceptible to oil injury, and both samples of kerosene were toxic to these plants. Toxicity of the heavy mineral seal oil to all plants was chronic in type. It may result from the small content of aromatic and olefinic material remaining in the oil after the solvent extraction and the heavy acid treatment. Since all plant species in the test were injured, perhaps the toxicants of oils in this range are lacking in selectivity. The wide differential between grass and flax with respect to toxicity from kerosene, on the other hand, promises a method for destroying wild oats in flax, a practical problem.

The refinement of fuel oils, especially Diesel oil, decreases the toxicity; and any refining processes that remove aromatic compounds would undoubtedly reduce the herbicidal effect of such oil. 


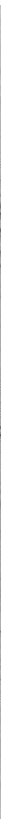

B

Heavy Fuel Oil. One attempt to counteract this tendency has been the mixing of heavier, less refined fuel oil with Diesel oil. Though this causes little or no increase in acute toxicity, it apparently enhances chronic toxicity and makes the results of oil spraying more lasting. Field observations have shown, furthermore, that where such a mixture of oils has been applied heavily on hoary cress, oil seepage into and around the crowns has resulted in killing the roots to as much as 12 inches below ground level.

To fortify Diesel oil, some have used U.S. no. 1 heavy fuel oil having a gravity of $14.1^{\circ}$.

Table 11 shows the viscosities of several blends of U.S. no. 1 fuel oil with a Diesel oil whose A.P.I. gravity rating is 32.3. These mixtures are all more difficult to spray than straight Diesel. The one-sixth and one-fourth U.S. fueloil mixtures are fluid enough to be handled readily in the field, but the heavier mixes do not cover well.

U.S. no. 1 fuel oil and Diesel oil were used in varying concentrations to spray grass cultures in the greenhouse. Table 12 presents the results. The grasses, being rather mature, were difficult to kill. The relative toxicities, however, indicate the properties of the oils.

This heavy fuel oil did not atomize well; the droplets that came from the sprayer gave the plants a speckled appearance. With time, however, these droplets spread so that after a day the plants had a uniform dark coating. The dilutions all covered well at the time they were applied.

As table 12 shows, the combination of one part of fuel oil with 3 parts of odorless kerosene was the most toxic of the lot. Evidently the heavy oil did 
not penetrate readily, whereas this dilution covered faster, penetrated well, and produced the greatest injury. This combination resembled Diesel oil in physical properties and approached it most nearly in toxicity. The injury

TABLE 10

Toxicity of Odorless Kerosene, Kerosene, and Mineral Seal Oil to Weeds, Grass, Carrots, and Flax; February 28, 1944

\begin{tabular}{|c|c|c|c|c|c|c|c|c|c|c|c|c|c|c|c|c|}
\hline \multirow{3}{*}{$\begin{array}{l}\text { Oil fraction and } \\
\text { amount applied } \\
\text { per culture }\end{array}$} & \multicolumn{16}{|c|}{ Injury to weeds $(W)$, grass $(G)$, carrots $(C)$, and flax $(F)$, in per cent } \\
\hline & \multicolumn{4}{|c|}{1 day } & \multicolumn{4}{|c|}{2 days } & \multicolumn{4}{|c|}{3 days } & \multicolumn{4}{|c|}{5 days } \\
\hline & W & G & $\mathbf{C}$ & $\mathbf{F}$ & $\mathbf{W}$ & G & $\mathbf{C}$ & $\mathbf{F}$ & W & G & $\mathbf{C}$ & $\mathbf{F}$ & W & G & $\mathbf{C}$ & $\mathbf{F}$ \\
\hline \multicolumn{17}{|l|}{ Kerosene: } \\
\hline $7.5 \mathrm{ml} \ldots$ & 2 & 0 & 0 & 0 & 2 & 0 & 0 & 0 & 4 & 0 & 0 & 0 & 4 & 0 & 0 & 0 \\
\hline $15.0 \mathrm{ml} \ldots \ldots \ldots \ldots$ & 1 & 0 & 0 & $\mathbf{0}$ & 2 & 0 & 0 & 0 & 2 & 0 & 0 & 0 & 4 & 5 & 0 & 0 \\
\hline \multicolumn{17}{|l|}{ Odorless kerosene: } \\
\hline $7.5 \mathrm{ml} \ldots \ldots \ldots \ldots$ & 0 & 0 & 0 & 0 & 0 & 0 & 0 & 0 & 0 & 0 & 0 & 0 & 2 & 10 & 0 & 0 \\
\hline $15.0 \mathrm{ml} \ldots \ldots \ldots$ & 0 & $\mathbf{0}$ & $\mathbf{0}$ & 0 & $\mathbf{0}$ & $\mathbf{0}$ & $\mathbf{0}$ & 0 & 0 & 0 & 0 & 0 & 5 & 20 & 0 & 0 \\
\hline \multicolumn{17}{|l|}{ Mineral seal oil: } \\
\hline $7.5 \mathrm{ml} \ldots \ldots$ & 0 & 0 & 0 & 0 & 0 & 0 & 0 & 0 & 0 & 0 & 0 & $\mathbf{0}$ & 1 & 0 & 10 & 0 \\
\hline \multirow[t]{3}{*}{$15.0 \mathrm{ml} . \ldots \ldots \ldots \ldots$} & 0 & 0 & 0 & 0 & 0 & 0 & 0 & 0 & 0 & 0 & 0 & $\mathbf{0}$ & 2 & $\mathbf{0}$ & 5 & 0 \\
\hline & \multicolumn{4}{|c|}{7 days } & \multicolumn{4}{|c|}{11 days } & \multicolumn{4}{|c|}{15 days } & \multicolumn{4}{|c|}{24 days } \\
\hline & W & $\mathrm{G}$ & C & $\mathbf{F}$ & $\mathbf{W}$ & G & C & $\mathbf{F}$ & W & G & $\mathrm{C}$ & $\mathbf{F}$ & W & G & C & F \\
\hline \multicolumn{17}{|l|}{ Kerosene: } \\
\hline $7.5 \mathrm{ml} \ldots$ & 0 & 10 & 0 & 0 & 0 & 50 & 0 & 0 & 0 & 75 & 0 & 0 & 0 & 100 & 0 & $\mathbf{0}$ \\
\hline $15.0 \mathrm{ml} . \ldots \ldots \ldots$ & 4 & 50 & 0 & 0 & 4 & 75 & 0 & 0 & 4 & 95 & 0 & 0 & 0 & 100 & 0 & 0 \\
\hline \multicolumn{17}{|l|}{ Odorless kerosene: } \\
\hline $7.5 \mathrm{ml} \ldots \ldots \ldots \ldots$ & 2 & 50 & 0 & 0 & 2 & 90 & 0 & 0 & 2 & 100 & 0 & 0 & 0 & 100 & 0 & 0 \\
\hline $15.0 \mathrm{ml} \ldots \ldots \ldots \ldots$ & 6 & 90 & 0 & 0 & 4 & 100 & 0 & 0 & 10 & 100 & 0 & 0 & 0 & 100 & 0 & 0 \\
\hline \multicolumn{17}{|l|}{ Mineral seal oil: } \\
\hline $7.5 \mathrm{ml} \ldots \ldots$ & 2 & 0 & 15 & 5 & 2 & 10 & 10 & 10 & 7 & 20 & 10 & 25 & 30 & 30 & 50 & 25 \\
\hline $15.0 \mathrm{ml} \ldots \ldots \ldots$ & 4 & 5 & 10 & 5 & 9 & 20 & 10 & 50 & 20 & 40 & 30 & 100 & 31 & 60 & 75 & 100 \\
\hline
\end{tabular}

* Weeds referred to here were Brassica, Amsinckia, and Lactuca species.

TABLE 11

Viscosity, Flash Point, and Gravity of Blends of Diesel and Fuel Oils

\begin{tabular}{|c|c|c|c|c|c|c|}
\hline \multirow{2}{*}{ Blend } & \multicolumn{4}{|c|}{ Viscosity, Saybolt, in seconds } & \multirow{2}{*}{$\begin{array}{c}\text { Flash } \\
\text { point } \\
\text { P.M.c.c.. }\end{array}$} & \multirow{2}{*}{$\begin{array}{l}\text { Gravity } \\
\text { A.P.I. }\end{array}$} \\
\hline & At $70^{\circ} \mathrm{F}$ & At $100^{\circ} \mathrm{F}$ & At $125^{\circ} \mathrm{F}$ & At $150^{\circ} \mathrm{F}$ & & \\
\hline Diesel oil $\ldots \ldots \ldots \ldots \ldots \ldots \ldots \ldots \ldots \ldots \ldots \ldots \ldots \ldots$ & 44.2 & 38.0 & 35.4 & 33.3 & 180 & 32.3 \\
\hline Diesel oil, 5 parts; U.S. fuel oil no. 1,1 part..... & 56.0 & 43.8 & 38.5 & 35.8 & 182 & 29.0 \\
\hline
\end{tabular}

was chronic and, with the heavy oil, developed only after several days. Had the test plants been young succulent barley, the general level of toxicity would have been higher; but the relative responses would not have been different.

Isoparaffins. Continued search for a nontoxic diluent led to the use of two isoparaffinic fractions that were reputedly 100 per cent unsulfonated. These 
were synthetic oils, polymerized from light aliphatic hydrocarbons and presumably free of aromatic and olefinic compounds. Table 13 shows the toxicity produced by these fractions, with that of other previously tested fractions

TABLE 12

'Toxicity of U.S. No. 1 Fuel Oil and Diesel Oil to Mixed Grasses;

MARCH 9, 1944

\begin{tabular}{|c|c|c|c|c|c|c|c|c|c|c|}
\hline \multirow{2}{*}{$\begin{array}{l}\text { Kind of oil and amounts } \\
\text { of oil and diluent } \\
\text { (odorless kerosene) } \\
\text { applied per culture }\end{array}$} & \multicolumn{10}{|c|}{ Injury to grasses, in per cent } \\
\hline & 1 day & 2 days & 4 days & 5 days & 9 days & 11 days & 14 days & 19 days & 22 days & 26 days \\
\hline \multicolumn{11}{|l|}{ Fuel oil: } \\
\hline $16 \mathrm{ml} \mathrm{FO}, 0 \mathrm{ml} \mathrm{OK} . .$. & 0 & 0 & $\mathbf{0}$ & 0 & 10 & 25 & 40 & 40 & 50 & 50 \\
\hline $8 \mathrm{ml} \mathrm{FO}, 8 \mathrm{ml} \mathrm{OK} \ldots$. & $\mathbf{0}$ & 0 & 0 & $\mathbf{5}$ & 25 & 50 & 60 & 60 & 65 & 65 \\
\hline $4 \mathrm{ml} \mathrm{FO}, 12 \mathrm{ml} \mathrm{OK} .$. & 0 & 0 & 5 & 15 & 60 & 85 & 90 & 95 & 98 & 98 \\
\hline $2 \mathrm{ml} \mathrm{FO}, 14 \mathrm{ml} \mathrm{OK} .$. & 0 & 0 & 10 & 25 & 60 & 90 & 90 & 75 & 80 & 80 \\
\hline $1 \mathrm{ml} \mathrm{FO}, 15 \mathrm{ml} \mathrm{OK} .$. & $\mathbf{0}$ & 0 & 20 & 50 & 70 & 90 & 90 & 70 & 70 & 70 \\
\hline \multicolumn{11}{|l|}{ Diesel oil: } \\
\hline $16 \mathrm{ml} \mathrm{DO}, 0 \mathrm{ml} \mathrm{OK} . .$. & 75 & 85 & 90 & 95 & 95 & 98 & 98 & 98 & 95 & 95 \\
\hline $8 \mathrm{ml} \mathrm{DO}, 8 \mathrm{ml} \mathrm{OK} \ldots$ & 25 & 50 & 75 & 85 & 90 & 95 & 95 & 95 & 90 & 85 \\
\hline $4 \mathrm{ml} \mathrm{DO}, 12 \mathrm{ml} \mathrm{OK} \ldots$ & 10 & 20 & 50 & 65 & 75 & 85 & 85 & 85 & 75 & 75 \\
\hline $2 \mathrm{ml} \mathrm{DO}, 14 \mathrm{ml} \mathrm{OK} .$. & 0 & 5 & 10 & 20 & 25 & 30 & 40 & 40 & 40 & 40 \\
\hline $1 \mathrm{ml} \mathrm{DO}, 15 \mathrm{ml} \mathrm{OK} .$. & 0 & 0 & 0 & 5 & 5 & 10 & 10 & 20 & 20 & 20 \\
\hline
\end{tabular}

TABLE 13

Toxicity of Isoparaffinic and Other OIL Fractions to Barley;

APRIL 18, 1944

\begin{tabular}{|c|c|c|c|c|c|}
\hline \multirow{2}{*}{ Age of plants and oil fraction } & \multicolumn{5}{|c|}{ Injury to barley, in per cent } \\
\hline & 1 day & 2 days & 4 days & 7 days & 9 days \\
\hline 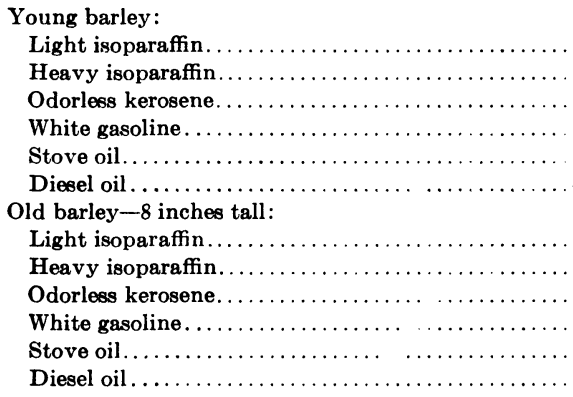 & $\begin{array}{r}0 \\
0 \\
0 \\
60 \\
75 \\
30 \\
\\
0 \\
0 \\
0 \\
10 \\
10 \\
0\end{array}$ & $\begin{array}{r}25 \\
0 \\
10 \\
100 \\
100 \\
75 \\
\\
0 \\
0 \\
0 \\
20 \\
40 \\
0\end{array}$ & $\begin{array}{r}40 \\
5 \\
25 \\
100 \\
100 \\
95 \\
\\
0 \\
0 \\
0 \\
50 \\
60 \\
50\end{array}$ & $\begin{array}{r}100 \\
20 \\
100 \\
100 \\
100 \\
100 \\
\\
30 \\
0 \\
25 \\
75 \\
95 \\
95\end{array}$ & $\begin{array}{r}100 \\
40 \\
100 \\
100 \\
100 \\
100 \\
\\
60 \\
20 \\
90 \\
85 \\
100 \\
100\end{array}$ \\
\hline
\end{tabular}

included for comparison. Tests were made on barley because that plant has proved most sensitive to oil.

Although these fractions were low in toxicity, they definitely injured barley. The light fraction was about twice as toxic as the heavy, and the injury was more like the acute effects of gasoline. White gasoline and stove oil caused severe acute injury ; Diesel oil, a chronic injury that proved fatal by the end of the test period. 


\section{ACID TREATMENT AND SOLVENT EXTRACTION}

As has long been recognized, the toxicity of oils to plants can be reduced by acid treatment and other refining processes (Gray and de Ong, 1926). These treatments remove aromatic and olefinic fractions as well as sulfur and nitrogen compounds. Presumably, the unsulfonated residues of heavy acid treatment and the raffinates from Edeleanu extraction are composed largely of aliphatic and naphthenic hydrocarbons.

Unsulfonated Residues of Stove Oil and Diesel Oil. Unsulfonated residues of stove oil and Diesel oil were prepared and tested in comparison with the untreated oils. Table 14 presents the results.

TABLE 14

Toxicity of Stove Oil, Diesel Oil, and Their Unsulfonated Residues on Brassica, Amsinckia, AND OTHER WeEDS ; * NoveMrer 1, 1943

\begin{tabular}{|c|c|c|c|c|c|c|c|c|c|}
\hline \multirow{3}{*}{ Oil fraction } & \multicolumn{9}{|c|}{ Injury to Brassica (B), Amsinckia (A), and other weeds (W), in per cent } \\
\hline & \multicolumn{3}{|c|}{1 day } & \multicolumn{3}{|c|}{2 days } & \multicolumn{3}{|c|}{3 days } \\
\hline & B & A & $\mathrm{w}$ & B & A & $\mathrm{w}$ & B & A & $\mathbf{w}$ \\
\hline Stove oil. . & 100 & 100 & 95 & 100 & 100 & 100 & 100 & 100 & 100 \\
\hline Stove oil, UR. & 0 & 10 & 5 & 0 & 60 & 5 & 10 & 90 & 5 \\
\hline Diesel oil.......... & 60 & 100 & 40 & 70 & 100 & 60 & 90 & 100 & 85 \\
\hline Diesel oil, UR...... & 10 & 10 & 15 & 10 & 10 & 15 & 10 & 20 & 20 \\
\hline
\end{tabular}

* Weeds referred to here were Stellaria and Lactuca species.

Although these readings did not carry through until chronic toxicity had developed fully, they do indicate a marked reduction in toxicity as a result of the heavy acid treatment. Toxicity is not eliminated, however; and the unsulfonated residues would not serve as nontoxic diluents.

The amount of injury caused by the unsulfonated residues of the experiment just described seemed high. For this reason, similar residues from four fractions each of stove oil and Diesel oil were made ready and compared with the untreated oils. Table 15 gives the results. The toxic materials left were most concentrated in the residues of the light fractions of stove oil. The Diesel-oil residues were free from compounds that might cause injury within 7 days. The weeds involved were mustard, fiddleneck, and annual sow thistle. A test on the toxicity of the unsulfonated residues of four gasoline fractions indicated higher values for the acute toxicity of the lighter fractions, as with stove oil. Chronic toxicity was higher in the heavier fractions (table 19, p. 104).

In a more detailed study of the toxicity of stove-oil residues, some narrower cuts were prepared, and each was sulfonated. Fractions $1 a$ and $1 b$ in table 16 were obtained by distillation of the previous fraction 1 to separate it into two equal portions. Original fractions 2 and 3 were similarly divided. Fraction 4 was sulfonated without separation, and its residue appears as number 4 in table 16. 
Table 16 confirms the observation that the lighter fractions of stove oil contain toxic materials that are not removed by sulfonation. The toxicity of the Diesel-oil residue reported in table 14 must have resulted from incomplete sul-

TABLE 15

Toxicity of Stove OIl and Diesel OIl and Their Unsulfonated Residues to Weeds* AND Carrots; November 17, 1943

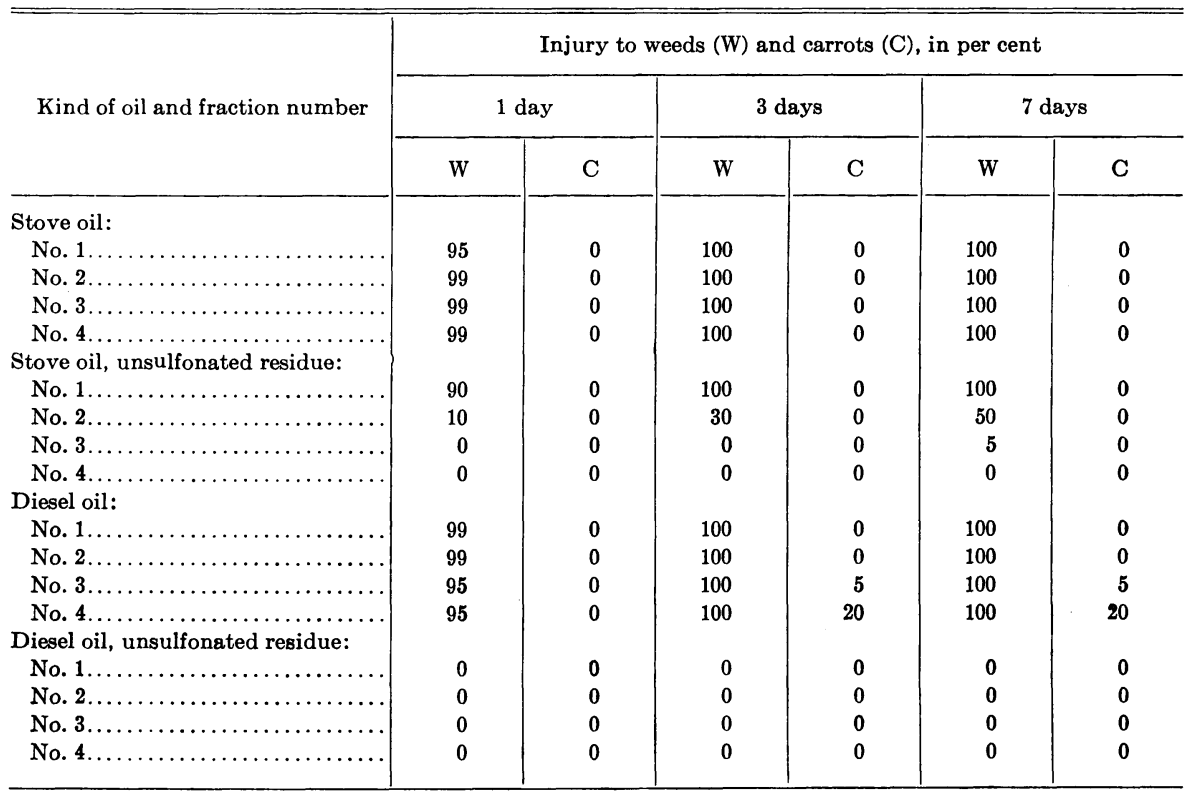

* Weeds referred to here were Brassica, Amsinckia, and Sonchus.

TABLE 16

Toxicity of Unsulfonated Residues of Stove OIL To Amsinckia, Lactuca, AND Grasses; November 27, 1943

\begin{tabular}{|c|c|c|c|c|c|c|}
\hline \multirow{2}{*}{$\begin{array}{l}\text { Unsulfonated residues of } \\
\text { stove oil, } \\
\text { fraction numbers }\end{array}$} & \multicolumn{3}{|c|}{1 day } & \multicolumn{3}{|c|}{3 days } \\
\hline & A & $\mathbf{L}$ & $\mathrm{G}$ & $\mathbf{A}$ & $\mathbf{L}$ & G \\
\hline No. $1 b \ldots \ldots \ldots \ldots \ldots \ldots \ldots$ & 90 & $\mathbf{5}$ & 30 & 100 & 10 & 50 \\
\hline No. $2 a \ldots \ldots \ldots \ldots \ldots \ldots$ & 50 & 5 & 10 & 80 & 10 & 10 \\
\hline No. $2 b \ldots \ldots \ldots \ldots \ldots \ldots$ & 10 & 0 & 0 & 15 & 0 & 5 \\
\hline No. $3 a \ldots$ & 5 & 0 & 0 & $\mathbf{5}$ & 0 & 0 \\
\hline No. $3 b \ldots \ldots \ldots \ldots$ & 0 & 0 & 0 & $\mathbf{0}$ & 0 & 0 \\
\hline
\end{tabular}

fonation or from the high greenhouse temperature'during the test. Although the unsulfonated residue from Diesel oil should, if properly prepared, have little or no acute toxicity, the development of chronic toxicity by mineral seal oil (table 10, p. 98) indicates that the Diesel-oil residue would act similarly if tested over a long period. 
Table 17 reports a more complete test of stove oil and its unsulfonated residue. The third and fourth fractions of Diesel oil are included, since they indicate the toxicity of fractions heavier than the heavier stove-oil cuts. These

TABLE 17

Toxicity of Stove-Oil Fractions, Diesel-Oil Fractions, and Fractions of the Unsulfonated Residue of Stove Oil on Amsinckia, Poa, Barley, Lactuca, AND CARROTS ; DeCEMBER 10, 1943

\begin{tabular}{|c|c|c|c|c|c|c|c|c|c|c|}
\hline \multirow{3}{*}{ Kind of oil and fraction number } & \multicolumn{10}{|c|}{$\begin{array}{l}\text { Injury to Amsinckia (A), Poa (P), barley (B), Lactuca (L), and } \\
\text { carrots (C), in per cent }\end{array}$} \\
\hline & \multicolumn{5}{|c|}{$1 \mathrm{day}$} & \multicolumn{5}{|c|}{3 days } \\
\hline & $\mathbf{A}$ & $\mathbf{P}$ & $\mathrm{B}$ & $\mathrm{L}$ & $\mathrm{C}$ & $\mathbf{A}$ & $\mathbf{P}$ & B & $\mathrm{L}$ & $\mathrm{C}$ \\
\hline \multicolumn{11}{|l|}{ Stove oil, unsulfonated residue: } \\
\hline No. $1 a \ldots \ldots \ldots \ldots \ldots \ldots$ & 90 & 60 & 70 & 0 & 0 & 100 & 95 & 90 & 0 & 0 \\
\hline No. $1 b \ldots \ldots \ldots \ldots \ldots \ldots \ldots \ldots \ldots$ & 90 & 30 & 30 & 0 & $\mathbf{0}$ & 95 & 60 & 80 & 0 & 0 \\
\hline No. $2 a \ldots \ldots \ldots \ldots \ldots \ldots \ldots \ldots \ldots \ldots$ & 50 & 15 & 10 & 0 & 0 & 100 & 70 & 50 & 5 & 0 \\
\hline$\ldots \ldots \ldots \ldots \ldots \ldots \ldots$ & 10 & 0 & 0 & 0 & 0 & 40 & 5 & 25 & 10 & 0 \\
\hline No. $3 a .$. & 0 & $\mathbf{0}$ & 0 & $\mathbf{0}$ & 0 & 5 & 0 & 0 & 10 & 0 \\
\hline No. $3 b$. & 0 & 0 & 0 & 0 & 0 & 0 & 0 & 0 & 10 & 0 \\
\hline$\ldots, \ldots, \cdots, \cdots, \ldots$ & 0 & 0 & 0 & 0 & 0 & 0 & 0 & 0 & 10 & 0 \\
\hline \multicolumn{11}{|l|}{ Stove oil: } \\
\hline No. $1 \ldots$ & 90 & 90 & 75 & 50 & 0 & 100 & 100 & 90 & 70 & 5 \\
\hline No. 2. & 90 & 90 & 75 & 40 & $\mathbf{0}$ & 100 & 100 & 75 & 60 & 5 \\
\hline No. 3. & 90 & 75 & 60 & 30 & 0 & 100 & 100 & 95 & 50 & 5 \\
\hline No. $4 \ldots \ldots \ldots \ldots \ldots \ldots \ldots$ & 75 & 50 & 20 & 10 & 0 & 100 & 100 & 90 & 40 & 5 \\
\hline \multicolumn{11}{|l|}{ Diesel oil: } \\
\hline No. $3 \ldots \ldots \ldots \ldots$ & 90 & 50 & 20 & 10 & 0 & 100 & 95 & 50 & 30 & 10 \\
\hline \multirow[t]{3}{*}{ No. $4 \ldots \ldots \ldots \ldots \ldots \ldots$} & 75 & 50 & 10 & $\mathbf{0}$ & 0 & 100 & 95 & 30 & 40 & 20 \\
\hline & \multicolumn{5}{|c|}{6 days } & \multicolumn{5}{|c|}{8 days } \\
\hline & A & $\mathbf{P}$ & B & $\mathbf{L}$ & C & A & $\mathbf{P}$ & B & $\mathbf{L}$ & $\mathrm{C}$ \\
\hline \multicolumn{11}{|l|}{ Stove oil, unsulfonated res due } \\
\hline No $1 a, \ldots \ldots \ldots \ldots \ldots \ldots$ & 100 & 100 & 100 & 5 & 0 & 100 & 100 & 100 & 0 & 0 \\
\hline No $1 b \ldots \ldots \ldots \ldots \ldots \ldots \ldots$ & 100 & 70 & 90 & 5 & 0 & 100 & 75 & 100 & 5 & 0 \\
\hline No. $: a \ldots \ldots \ldots \ldots \ldots \ldots \ldots \ldots$ & 100 & 90 & 90 & 5 & 0 & 100 & 95 & 100 & 5 & 0 \\
\hline No $2 b \ldots \ldots \ldots \ldots \ldots$ & 75 & 5 & 75 & 10 & 0 & 90 & 10 & 100 & $\mathbf{5}$ & 0 \\
\hline No $3 a \ldots \ldots \ldots \ldots \ldots$ & 20 & 0 & 25 & 10 & 0 & 30 & 0 & 40 & 10 & 0 \\
\hline No $3 b \ldots$ & 5 & 0 & 10 & 10 & 0 & 20 & 0 & 20 & 10 & 0 \\
\hline No. $4 \ldots \ldots \ldots \ldots \ldots \ldots$ & 0 & 0 & 0 & 10 & 0 & 0 & 0 & 0 & 5 & 0 \\
\hline \multicolumn{11}{|l|}{ Stove oil: } \\
\hline No. $1 \ldots$ & 100 & 100 & 100 & 100 & 5 & 100 & 100 & 100 & 100 & 5 \\
\hline No. $2 \ldots$ & 100 & 100 & 50 & 75 & 5 & 100 & 100 & 50 & 75 & 5 \\
\hline No. $3 \ldots \ldots \ldots \ldots \ldots \ldots \ldots \ldots \ldots \ldots \ldots \ldots$ & 100 & 100 & 100 & 60 & $\mathbf{5}$ & 100 & 100 & 100 & 90 & 5 \\
\hline No. $4 \ldots \ldots \ldots \ldots \ldots \ldots \ldots \ldots \ldots \ldots \ldots \ldots \ldots \ldots$ & 100 & 100 & 95 & 90 & 5 & 100 & 100 & 100 & 100 & 5 \\
\hline \multicolumn{11}{|l|}{ Diesel oil: } \\
\hline 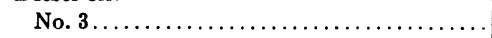 & 100 & 100 & 60 & 50 & 10 & 100 & 100 & 75 & 80 & 10 \\
\hline 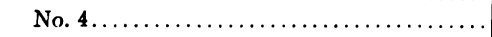 & 100 & 100 & 10 & 40 & 50 & 100 & 100 & 75 & 50 & 50 \\
\hline
\end{tabular}

data show definitely that the lighter residues of stove oil are toxic, but that different plant species respond differently to this toxicity; and they prove again the fact that Diesel-oil fractions from the heavy end cause chronic toxicity to carrots.

One short experiment was conducted to test the effect of sulfonation on the heavy isoparaffin reported in table 13 . The results proved that some sul- 
fonatable material accounts for the toxicity of the fraction. The unsulfonated residue of the isoparaffin displayed no toxicity within the 8-day observation period (see, however, table 18).

The storage tests reported in the section on toxicity of gasoline and of similar light fractions (p. 116 to 120) show that certain refined fractions tended to increase in toxicity. After these tests, unsulfonated residues of stored lots of stove oil and of the heavy isoparaffinic fraction were prepared. To rid the residues of a turbidity that developed during sulfonation, they

TABLE 18

Toxicity to Flax, Barley, and Carrots, of Unsulfonated Reisidues of Stove, Oil AND IsoparafFin Exposf.d To Light ; November 29, 1945

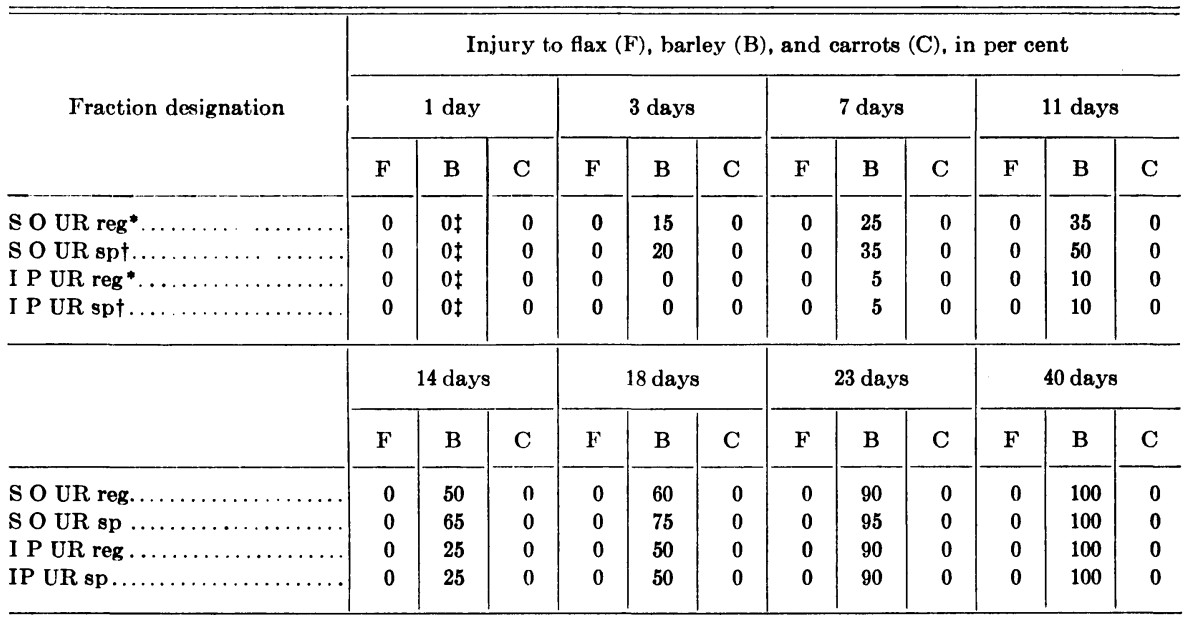

* S O URreg was an unsulfonated residue of stove oil prepared in the usual way. I P URreg was a similar residue from the heavy isoparaffinic fraction first reported in table 13 .

t S O URsp and I P URsp refer to the light clear fraction separated from portions of the regular fractions by centrifugation.

$\ddagger$ Barley plants all exhibited reversed geotropism on the first day after treatment with these four fractions.

were centrifuged. The small, clear fraction which then separated out on top of the main body of the liquid was decanted and marked URsp. This label indicated a special fraction, whereas URreg designated ordinary residues like those used in previous tests. The two types of residue from both stove oil and isoparaffin were tested on flax, barley, and carrots, with the results shown in table 18. Under the conditions of the test these fractions were toxic only to barley ; flax and carrots were uninjured.

The first evidence of response by barley was a reversed geotropism shown on the day after spraying. On the second day the stove-oil residues injured the barley visibly ; injury gradually developed from all treatments, the barley being dead 40 days after spraying. The isoparaffin fractions were slower acting than the stove-oil residues; there was no difference between the centrifuged and regular residues. Barley sprayed with all four unsulfonated residues became severely infected with powdery mildew during the tests, and this fungus hastened the death of the plants. Unsprayed controls were only lightly infected. 
Studies on the unsulfonated residues of gasoline fractions proved these to be even more toxic than those of stove oil reported in tables 1,3 , and 4 (p. 86 and 87). Results are given in table 19.

\section{TABLE 19}

Toxicity of Unsulfonated Residues of Gasoline Fractions* to Grass and Broad-Leaved Weeds; November 11, 1944

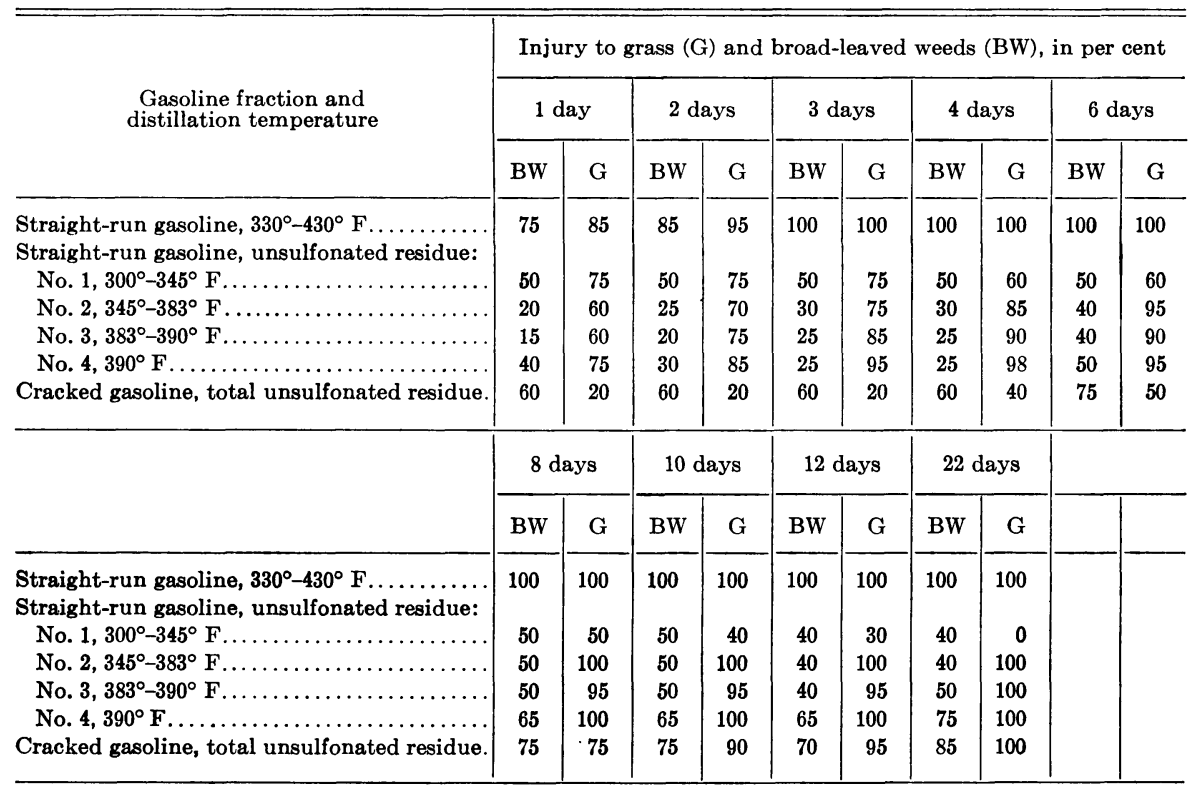

* This was a special sample of straight-run gasoline supplied through the courtesy of the Shell Oil Company.

TABLE 20

Toxicity of Edeleanu Extract, Technical Toluene Solvent, Gasoline, and Kerosene to Poa annua, Barley, and Carrots; January 8, 1944

\begin{tabular}{|c|c|c|c|c|c|c|}
\hline \multirow{3}{*}{ Oil fraction } & \multicolumn{6}{|c|}{ Toxicity to Poa annua (P), barley (B), and carrots (C), in per cent } \\
\hline & \multicolumn{3}{|c|}{1 day } & \multicolumn{3}{|c|}{3 days } \\
\hline & $\mathbf{P}$ & B & $\mathbf{C}$ & $\mathbf{P}$ & B & $\mathbf{C}$ \\
\hline E-1295 ...... & 100 & 100 & 100 & 100 & 100 & 100 \\
\hline TS-28....... & 100 & 100 & 100 & 100 & 100 & 100 \\
\hline Gasoline............................ & 100 & 75 & 0 & 100 & 75 & 0 \\
\hline Kerosene........................... & 0 & 0 & 0 & 0 & 0 & 0 \\
\hline
\end{tabular}

Although these values are lower than those for the total gasoline fractions of tables 8 and 9 (p. 94 and 95), they are still very high for acid-treated samples. They indicate that sulfonation does not free these light fractions of toxic compounds. Evidently such compounds within this boiling range do not decompose readily under the influence of concentrated sulfuric acid. 
Toxicity of the lightest unsulfonated residue was principally acute. The heavier materials contained enough of the heavier unsaturates to be lethal to grasses by the end of the 22-day observation period. The unsulfonated residue from the cracked gasoline, though Iow in acute toxicity, had the highest total toxicity by the end of the experiment.

Products of Solvent Extraction. Samples of Edeleanu extract, ${ }^{8}$ raffinate, and various products resulting from further refinement of the extract have been tested for toxicity and selectivity. Being high in aromatic and olefinic compounds, the extract is naturally high in toxicity. Table 20 shows results of a preliminary test with gasoline, kerosene, Edeleanu extract (E-1295), and a technical solvent (TS-28) produced by fractional distillation of the extract. The extracts proved extremely high in acute toxicity.

In the refinement of Edeleanu extract for the production of commercial solvents, an end product is placed on the market by the Tidewater Associated Oil Company under the name Avon Weed Killer. This material is high in aromatic and olefinic compounds. According to specifications provided by the manufacturer, it has the following physical properties :

Gravity, A.P.I.: $19.0^{\circ}$ to $46.5^{\circ}$

Flash (Pensky-Martens closed cup), minimum: $150^{\circ} \mathrm{F}$

Viscosity, Saybolt Universal at $100^{\circ} \mathrm{F}$ maximum: 50 sec.

Initial boiling point: about $400^{\circ} \mathrm{F}$

Final boiling point: about $700^{\circ} \mathrm{F}$

Table 21 gives results of a test comparing Edeleanu extract with Avon Weed Killer at various concentrations, odorless kerosene being used as a diluent. Both products are high in acute toxicity; but this drops off rapidly with dilution, especially on carrots. The Avon Weed Killer, being heavier than the original extract, has a somewhat higher chronic toxicity.

More detailed information on the toxicity of these products is contained in table 22, which compares four fractions of gasoline, E-1295, and Avon Weed Killer. The gasoline was used at 100 per cent and 75 per cent concentrations, whereas E-1295 and Avon were used at 25 per cent and 12.5 per cent. This difference was used to bring the gasoline into a comparable toxicity range. As these data show, the heavier fractions of all three of these products are the more toxic. The high volatility of the light fractions may partly explain these results.

To ascertain how extraction affects the toxicity of a medium-weight petroleum fraction, studies were made on a series of fractional extracts of kerosene distillate. Gravities of the extracts were as follows :

\begin{tabular}{|c|c|c|c|c|c|}
\hline & E-1296 & E-1297 & E-1298 & E-1299 & E-1300 \\
\hline$n t$ of fe & 7.6 & 8.7 & 3.1 & 4.7 & 75.9 \\
\hline Gravit & $22.2^{\circ}$ & $23.0^{\circ}$ & $27.5^{\circ}$ & $32.8^{\circ}$ & $44.0^{\circ}$ \\
\hline
\end{tabular}

These figures prove that the initial extraction takes out the heavier of the aromatic and olefinic compounds, the gravity shifting with successive extractions in the direction of lighter fractions.

Table 23 presents the results of these tests, the data being taken on grass and carrot cultures. As these figures show, the first extract (E-1296) was almost identical with the total extract (E-1295) ; the second extract was almost iden-

${ }^{8}$ See footnote 9, p. 112. 


\section{TABLE 21}

Toxigity of Edeleanu Extract and Avon Weed Killer to Carrots, Grass, AND Chenopodium murale; FebRUARY 3, 1944

\begin{tabular}{|c|c|c|c|c|c|c|c|c|c|c|c|c|c|c|c|}
\hline \multirow{3}{*}{$\begin{array}{l}\text { Kind of oil and amounts } \\
\text { of oil and diluent } \\
\text { (odorless kerosene) } \\
\text { applied per culture }\end{array}$} & \multicolumn{15}{|c|}{ Injury to carrots $(\mathrm{C})$, grass $(\mathrm{G})$, and Chenopodium murale $(\mathrm{Cm})$, in per cent } \\
\hline & \multicolumn{3}{|c|}{2 days } & \multicolumn{3}{|c|}{4 days } & \multicolumn{3}{|c|}{8 days } & \multicolumn{3}{|c|}{12 days } & \multicolumn{3}{|c|}{18 days } \\
\hline & $\mathrm{C}$ & G & $\mathrm{Cm}$ & $\mathrm{C}$ & G & $\mathrm{Cm}$ & C & G & $\mathrm{Cm}$ & C & G & $\mathrm{Cm}$ & C & G & $\mathrm{Cm}$ \\
\hline \multicolumn{16}{|l|}{ Edeleanu extract: } \\
\hline - $10 \mathrm{ml} \mathrm{E}, 0 \mathrm{ml} \mathrm{OK}$ & 75 & 95 & 95 & 95 & 100 & 100 & 100 & 100 & 100 & 100 & 100 & 100 & 100 & 100 & 100 \\
\hline $5 \mathrm{ml} \mathrm{E}, 5 \mathrm{ml} \mathrm{OK} \ldots .$. & 25 & 95 & 95 & 25 & 100 & 100 & 20 & 100 & 100 & 20 & 100 & 100 & 25 & 100 & 100 \\
\hline $21 / 2 \mathrm{ml} \mathrm{E}, 71 / 2 \mathrm{ml} \mathrm{OK}$. & 0 & 95 & 90 & 0 & 100 & 100 & 0 & 100 & 100 & 0 & 100 & 100 & 5 & 100 & 100 \\
\hline $11 / 4 \mathrm{ml} \mathrm{E}, 83 / 4 \mathrm{ml} \mathrm{OK}$. & $\mathbf{0}$ & 70 & 90 & $\mathbf{0}$ & 75 & 100 & 0 & 90 & 100 & $\mathbf{0}$ & 95 & 100 & $\mathbf{0}$ & 97 & 100 \\
\hline $5 / 8 \mathrm{ml} \mathrm{E}, 93 / 8 \mathrm{ml} \mathrm{OK}$ & 0 & 15 & 20 & 0 & 40 & 40 & 0 & 60 & 60 & 0 & 70 & 60 & 0 & 80 & 50 \\
\hline \multicolumn{16}{|l|}{ Avon Weed Killer: } \\
\hline $10 \mathrm{ml} \mathrm{A}, 0 \mathrm{ml} \mathrm{OK}$. & 50 & 95 & 95 & 75 & 100 & 100 & 100 & 100 & 100 & 100 & 100 & 100 & 100 & 100 & 100 \\
\hline $5 \mathrm{ml} \mathrm{A}, 5 \mathrm{ml} \mathrm{OK} \ldots \ldots$ & 10 & 95 & 95 & 25 & 100 & 100 & 25 & 100 & 100 & 25 & 100 & 100 & 25 & 100 & 100 \\
\hline $21 / 2 \mathrm{ml} \mathrm{A}, 71 / 2 \mathrm{ml} \mathrm{OK}$. & 0 & 90 & 90 & $\mathbf{5}$ & 100 & 100 & 5 & 100 & 100 & $\mathbf{5}$ & 100 & 100 & 10 & 100 & 100 \\
\hline $11 / 4 \mathrm{ml} \mathrm{A}, 83 / 4 \mathrm{ml} \mathrm{OK}$ & $\mathbf{0}$ & 30 & 75 & 0 & 60 & 95 & 0 & 100 & 50 & 0 & 95 & 100 & 5 & 98 & 100 \\
\hline $5 / 8 \mathrm{ml} \mathrm{A}, 98 / 8 \mathrm{ml} \mathrm{OK}$. & 0 & 10 & 20 & 0 & 30 & 90 & 0 & 75 & 20 & $\mathbf{0}$ & 75 & 95 & 0 & 80 & 100 \\
\hline
\end{tabular}

TABLE 22

Toxicity of Oil Fractions to Malva, and Grasses ;

February 23, 1944

\begin{tabular}{|c|c|c|c|c|c|c|c|c|c|c|c|c|}
\hline \multirow{3}{*}{$\begin{array}{l}\text { Oil fraction and amounts of fraction (F) } \\
\text { and diluent } \\
\text { (odorless kerosene) applied per culture }\end{array}$} & \multicolumn{12}{|c|}{ Injury to Malva (M) and grasses (G), in per cent } \\
\hline & \multicolumn{2}{|c|}{1 day } & \multicolumn{2}{|c|}{2 days } & \multicolumn{2}{|c|}{3 days } & \multicolumn{2}{|c|}{5 days } & \multicolumn{2}{|c|}{7 days } & \multicolumn{2}{|c|}{12 days } \\
\hline & $\mathbf{M}$ & G & $\mathbf{M}$ & G & $\mathbf{M}$ & G & $\mathbf{M}$ & G & $\mathbf{M}$ & $\mathrm{G}$ & $\mathbf{M}$ & G \\
\hline \multicolumn{13}{|l|}{ Gasoline: } \\
\hline No. $1,10 \mathrm{ml} \mathrm{F,} 0 \mathrm{ml} \mathrm{OK} \ldots$ & 60 & 20 & 60 & 20 & 70 & 20 & 75 & 25 & 70 & 20 & 75 & 25 \\
\hline No. $1,71 / 2 \mathrm{ml} \mathrm{F}, 21 / 2 \mathrm{ml} \mathrm{OK}$. & 40 & 10 & 40 & 10 & 50 & 10 & 50 & 20 & 40 & 10 & 40 & 20 \\
\hline No. $2,10 \mathrm{ml} \mathrm{F}, 0 \mathrm{ml} \mathrm{OK} \ldots$ & 90 & 90 & 95 & 95 & 99 & 97 & 99 & 100 & 99 & 99 & 100 & 100 \\
\hline No. $2,71 / 2 \mathrm{ml} \mathrm{F}, 21 / 2 \mathrm{ml} \mathrm{OK}$. & 80 & 75 & 90 & 85 & 95 & 90 & 95 & 90 & 90 & 90 & 90 & 95 \\
\hline No. $3,10 \mathrm{ml} \mathrm{F}, 0 \mathrm{ml} \mathrm{OK} \ldots$ & 95 & 90 & 100 & 95 & 100 & 99 & 100 & 100 & 100 & 100 & 100 & 100 \\
\hline No. $3,71 / 2 \mathrm{ml} \mathrm{F}, 21 / 2 \mathrm{ml} \mathrm{OK}$. & 80 & 90 & 80 & 95 & 80 & 100 & 90 & 100 & 90 & 100 & 90 & 100 \\
\hline No. $4,10 \mathrm{ml} \mathrm{F}, 0 \mathrm{ml} \mathrm{OK} \ldots$ & 100 & 100 & 100 & 100 & 100 & 100 & 100 & 100 & 100 & 100 & 100 & 100 \\
\hline No. $4,71 / 2 \mathrm{ml} \mathrm{F}, 21 / 2 \mathrm{ml} \mathrm{OK}$. & 80 & 95 & 80 & 95 & 85 & 98 & 85 & 100 & 85 & 100 & 90 & 100 \\
\hline \multicolumn{13}{|l|}{ Edeleanu extract: } \\
\hline No. $1,21 / 2 \mathrm{ml} \mathrm{F}, 71 / 2 \mathrm{ml} \mathrm{OK}$. & 65 & 50 & 70 & 75 & 75 & 80 & 75 & 85 & 70 & 90 & 75 & 100 \\
\hline No. $1,11 / 4 \mathrm{ml} \mathrm{F}, 83 / 4 \mathrm{ml} \mathrm{OK}$. & 25 & $\mathbf{5}$ & 30 & 10 & 40 & 20 & 40 & 20 & 40 & 20 & 50 & 25 \\
\hline No. $2,21 / 2 \mathrm{ml} \mathrm{F}, 71 / 2 \mathrm{ml} \mathrm{OK}$. & 80 & 65 & 80 & 90 & 90 & 95 & 90 & 100 & 90 & 100 & 90 & 100 \\
\hline Nc. $2,11 / 4 \mathrm{ml} \mathrm{F}, 83 / 4 \mathrm{ml} \mathrm{OK}$. & 50 & 20 & 50 & 10 & 65 & 20 & 65 & 40 & 75 & 40 & 75 & 60 \\
\hline No. $3,21 / 2 \mathrm{ml} \mathrm{F}, 71 / 2 \mathrm{ml} \mathrm{OK}$. & 90 & 75 & 90 & 95 & 95 & 100 & 97 & 100 & 97 & 100 & 97 & 100 \\
\hline No. $3,11 / 4 \mathrm{ml} \mathrm{F}, 83 / 4 \mathrm{ml} \mathrm{OK}$ & 70 & 40 & 70 & 40 & 70 & 60 & 75 & 75 & 75 & 80 & 75 & 95 \\
\hline No. $4,21 / 2 \mathrm{ml} \mathrm{F}, 71 / 2 \mathrm{ml} \mathrm{OK}$. & 100 & 100 & 100 & 100 & 100 & 100 & 100 & 100 & 100 & 100 & 100 & 100 \\
\hline No. $4,11 / 4 \mathrm{ml} \mathrm{F}, 83 / 4 \mathrm{ml}$ OK. & 95 & 75 & 100 & 75 & 100 & 90 & 100 & 90 & 100 & 90 & 100 & 95 \\
\hline \multicolumn{13}{|l|}{ Avon Weed Killer: } \\
\hline No. $1,21 / 2 \mathrm{ml} \mathrm{F}, 71 / 2 \mathrm{ml} \mathrm{OK}$ & 75 & 60 & 75 & 90 & 80 & 95 & 85 & 100 & 85 & 100 & 75 & 100 \\
\hline No. $1,11 / 4 \mathrm{ml} \mathrm{F}, 83 / 4 \mathrm{ml} \mathrm{OK}$. & 50 & 30 & 50 & 40 & 50 & 50 & 65 & 75 & 75 & 75 & 60 & 90 \\
\hline No. $2,21 / 2 \mathrm{ml} \mathrm{F}, 7 \frac{1}{2} \mathrm{ml} \mathrm{OK}$. & 90 & 75 & 90 & 95 & 97 & 99 & 100 & 100 & 100 & 100 & 100 & 100 \\
\hline No. $2,11 / 4 \mathrm{ml} \mathrm{F}, 88 / 4 \mathrm{ml} \mathrm{OK}$. & 75 & 50 & 75 & 60 & 75 & 75 & 75 & 75 & 75 & 75 & 75 & 90 \\
\hline No. $3,21 / 2 \mathrm{ml} \mathrm{F}, 71 / 2 \mathrm{ml} \mathrm{OK}$. & 95 & 85 & 99 & 95 & 100 & 100 & 100 & 100 & 100 & 100 & 100 & 100 \\
\hline No. $3,11 / 4 \mathrm{ml} \mathrm{F}, 83 / 4 \mathrm{ml} \mathrm{OK}$. & 85 & 70 & 90 & 75 & 95 & 85 & 95 & 90 & 95 & 90 & 90 & 95 \\
\hline No. $4,21 / 2 \mathrm{ml} \mathrm{F}, 71 / 2 \mathrm{ml} \mathrm{OK}$. & 100 & 95 & 100 & 100 & 100 & 100 & 100 & 100 & 100 & 100 & 100 & 100 \\
\hline No. $4,11 / 4 \mathrm{ml} \mathrm{F}, 83 / 4 \mathrm{ml} \mathrm{OK} \ldots \ldots \ldots$ & 95 & 85 & 95 & 90 & 98 & 95 & 100 & 100 & 100 & 100 & 100 & 100 \\
\hline
\end{tabular}


TABLE 23

Toxicity of Fractional Extracts of Kerosene Distillate on Grass and Carrots; J ANUARY 15, 1944

\begin{tabular}{|c|c|c|c|c|c|c|c|c|c|c|c|c|c|c|c|c|c|c|c|c|c|c|}
\hline \multirow{3}{*}{$\begin{array}{l}\text { Refinery } \\
\text { fraction } \\
\text { designa- } \\
\text { tion }\end{array}$} & \multirow{2}{*}{\multicolumn{4}{|c|}{$\begin{array}{c}\begin{array}{c}\text { Injury to carrots, } \\
\text { in per cent }\end{array} \\
\text { Pure fraction }\end{array}$}} & \multicolumn{18}{|c|}{ Injury to grass, in per cent } \\
\hline & & & & & \multicolumn{4}{|c|}{ Pure fraction } & \multicolumn{4}{|c|}{$\begin{array}{l}1 \text { part fraction, } \\
1 \text { part OK }\end{array}$} & \multicolumn{5}{|c|}{$\begin{array}{l}1 \text { part fraction, } \\
3 \text { parts } O K\end{array}$} & \multicolumn{5}{|c|}{$\begin{array}{l}1 \text { part fraction, } \\
7 \text { parts } O K\end{array}$} \\
\hline & $\begin{array}{c}1 \\
\text { day }\end{array}$ & $\underset{\text { days }}{2}$ & $\begin{array}{c}* 3 \\
\text { days }\end{array}$ & 10 & $\begin{array}{c}1 \\
\text { day }\end{array}$ & $\underset{\text { days }}{2}$ & $\begin{array}{c}* 3 \\
\text { days }\end{array}$ & $\begin{array}{c}10 \\
\text { days }\end{array}$ & $\begin{array}{c}1 \\
\text { day }\end{array}$ & $\underset{\text { days }}{2}$ & $\stackrel{\dagger 3}{\text { days }}$ & $\begin{array}{c}10 \\
\text { days }\end{array}$ & $\begin{array}{c}1 \\
\text { day }\end{array}$ & $\underset{\text { days }}{2}$ & s ${ }_{\text {days }}^{3}$ & days & $\begin{array}{c}10 \\
\text { days }\end{array}$ & $\begin{array}{c}1 \\
\text { day }\end{array}$ & $\underset{2}{2}$ & $\begin{array}{c}3 \\
\text { days }\end{array}$ & $\begin{array}{c}5 \\
\text { days }\end{array}$ & $\begin{array}{c}10 \\
\text { days }\end{array}$ \\
\hline E-1295. & 100 & 100 & 100 & 100 & 100 & 100 & 100 & 100 & 100 & 100 & 100 & 100 & 95 & 100 & 100 & 100 & 100 & 25 & 50 & 50 & 60 & 75 \\
\hline E-129 & 100 & 100 & 100 & 100 & 100 & 100 & 100 & 100 & 100 & 100 & 100 & 100 & 75 & 100 & 100 & 100 & 100 & 25 & 50 & 50 & 60 & 75 \\
\hline E-1297.. & 100 & 100 & 100 & 100 & 100 & 100 & 100 & 100 & 100 & 100 & 100 & 100 & 90 & 100 & 100 & 100 & 100 & 50 & 75 & 50 & 70 & 75 \\
\hline E-1298. . & 50 & 95 & 100 & 100 & 90 & 100 & 100 & 100 & 90 & 100 & 100 & 100 & 80 & 95 & 95 & 95 & 98 & 10 & 50 & 30 & 30 & 60 \\
\hline E-1299.. & 90 & 95 & 100 & 100 & 90 & 100 & 100 & 100 & 75 & 100 & 95 & 100 & 60 & 90 & 80 & 90 & 90 & 10 & 10 & 10 & 20 & 40 \\
\hline E-1300.. & 0 & 0 & 0 & 0 & 10 & 10 & 0 & 5 & $\mathbf{5}$ & $\mathbf{5}$ & 0 & 5 & 0 & 0 & 0 & 0 & $\mathbf{0}$ & 0 & 0 & 0 & 0 & 0 \\
\hline TS-28.... & 100 & 100 & 100 & 100 & 100 & 100 & 100 & 100 & 90 & 100 & 100 & 100 & 90 & 100 & 100 & 100 & 98 & 20 & 40 & 20 & 20 & 20 \\
\hline
\end{tabular}

- Injury at 5 days was the same as at 3 days.

$\dagger$ Injury at 5 days was the same as at 3 days except for fraction E-1299, which showed 100 per cent injury.

TABLE 24

Toxicity of Tar OIL Residues to Foxtail Sod; January 27, 1945

\begin{tabular}{|c|c|c|c|c|c|c|c|c|c|c|c|c|c|c|}
\hline \multirow{3}{*}{$\begin{array}{l}\text { Amount of residue (R) } \\
\text { and diluent (isoparaffin) } \\
\text { applied per culture }\end{array}$} & \multicolumn{14}{|c|}{ Injury to foxtail, in per cent } \\
\hline & \multicolumn{7}{|c|}{ Crude still residue: isoparaffin mixtures } & \multicolumn{7}{|c|}{ Pure still residue : isoparaffin mixtures } \\
\hline & $\begin{array}{c}1 \\
\text { day }\end{array}$ & $\underset{\text { days }}{2}$ & $\begin{array}{c}3 \\
\text { days }\end{array}$ & $\begin{array}{c}4 \\
\text { days }\end{array}$ & $\begin{array}{c}6 \\
\text { days }\end{array}$ & $\begin{array}{c}9 \\
\text { days }\end{array}$ & $\begin{array}{c}13 \\
\text { days }\end{array}$ & $\begin{array}{c}1 \\
\text { day }\end{array}$ & $\begin{array}{c}2 \\
\text { days }\end{array}$ & $\begin{array}{c}3 \\
\text { days }\end{array}$ & $\begin{array}{c}4 \\
\text { days }\end{array}$ & $\begin{array}{c}6 \\
\text { days }\end{array}$ & $\begin{array}{c}9 \\
\text { days }\end{array}$ & $\begin{array}{c}13 \\
\text { days }\end{array}$ \\
\hline $6 \mathrm{ml} \mathrm{R}, 0 \mathrm{ml} \mathrm{IP.}$ & 100 & 100 & 100 & 100 & 100 & 100 & 100 & 25 & 90 & 98 & 98 & 98 & 98 & 99 \\
\hline $3 \mathrm{ml} \mathrm{R}, 3 \mathrm{ml} \mathrm{IP.....}$ & 100 & 100 & 100 & 100 & 100 & 100 & 100 & 15 & 80 & 95 & 95 & 98 & 98 & 99 \\
\hline $11 / 2 \mathrm{ml} \mathrm{R}, 41 / 2 \mathrm{ml} \mathrm{lP}$ & 25 & 50 & 75 & 85 & 95 & 98 & 100 & $\mathbf{5}$ & 50 & 90 & 95 & 95 & 98 & 99 \\
\hline $3 / 4 \mathrm{~m} ! \mathrm{R}, 51 / 4 \mathrm{ml} \mathrm{IP}$. & 0 & 5 & 5 & 10 & 15 & 20 & 20 & 0 & 20 & 80 & 90 & 95 & 98 & 99 \\
\hline $8 / 8 \mathrm{ml} \mathrm{R}, 55 / 8 \mathrm{ml} \mathrm{IP} \ldots$ & 0 & 0 & 2 & 5 & $\mathbf{5}$ & 10 & 10 & 0 & 10 & 50 & 85 & 85 & 90 & 90 \\
\hline $3 / 16 \mathrm{ml} \mathrm{R}, 5^{13 / 16} \mathrm{ml} \mathrm{IP...}$ & 0 & 0 & 1 & 1 & 2 & 10 & 10 & 0 & 5 & 25 & 50 & 50 & 75 & 75 \\
\hline $3 / 32 \mathrm{ml} \mathrm{R}, 5^{29 / 32} \mathrm{ml} \mathrm{IP} \ldots$ & 0 & 0 & 1 & 1 & 2 & 10 & 10 & 0 & 0 & 5 & 10 & 20 & 60 & 75 \\
\hline $3 / 64 \mathrm{ml} \mathrm{R}, 5^{61 / 64 \mathrm{ml} \mathrm{IP} \ldots \ldots}$ & 0 & 0 & 1 & 1 & 2 & 10 & 10 & 0 & 0 & 1 & 10 & 20 & 60 & 75 \\
\hline
\end{tabular}

tical with the first; and the extracts that followed were successively weaker in herbicidal effect. The final raffinate (E-1300), which resembled odorless kerosene in properties, was nontoxic to carrots and only slightly injurious to grass. The TS-28 solvent, a highly aromatic fraction, was of the same order of toxicity as the total extract (E-1295) and the first extract (E-1296). Boiling points and gravities on some of these fractions were as follows :

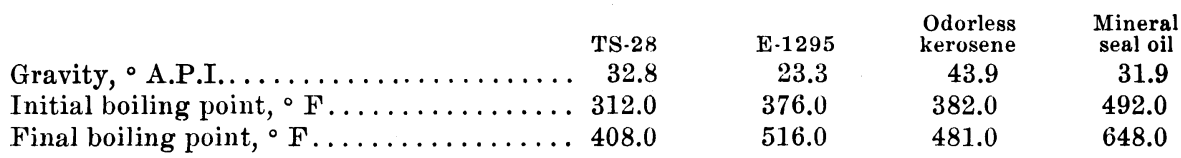

Whereas these unsaturated compounds are highly toxic, when diluted they are less toxic; and any mixture containing less than about 25 per cent is too 
dilute to be useful as a herbicide. The pure fractions killed carrots; the mixtures containing 12.5 per cent of the extracts were low in toxicity to carrots and not injurious enough to grass to make effective herbicides.

Coke-Still Residues. Two additional fractions high in aromatic compounds were tested for toxicity. These were (1) crude still residue, a dark fluid obtained from the coke ovens at Fontana, California; and (2) pure still

TABLE 25

Toxicity of Acid-treated Gasoline Samples to Foxtail Sod; Attempted Separation of Olefins and Aromatics; Jandary 27, 1945

\begin{tabular}{|c|c|c|c|c|c|c|c|}
\hline \multirow{2}{*}{$\begin{array}{l}\text { Fraction and amounts of fraction }(\mathrm{F}) \\
\text { and diluent (isoparaffin) } \\
\text { applied per culture }\end{array}$} & \multicolumn{7}{|c|}{ Injury to foxtail sod, in per cent } \\
\hline & 1 day & 2 days & 3 days & 4 days & 6 days & 9 days & 13 days \\
\hline \multicolumn{8}{|l|}{ E-1380: } \\
\hline $6 \mathrm{ml} \mathrm{F}, 0 \mathrm{ml} \mathrm{IP} \ldots \ldots \ldots \ldots \ldots \ldots$ & 100 & 100 & 100 & 100 & 100 & 100 & 100 \\
\hline 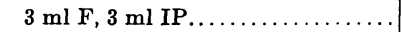 & 90 & 95 & 95 & 95 & 100 & 100 & 100 \\
\hline $1.5 \mathrm{ml} \mathrm{F}, 4.5 \mathrm{ml} \mathrm{IP} \ldots \ldots \ldots \ldots \ldots$ & 10 & 10 & 10 & 10 & 15 & 25 & 40 \\
\hline $0.8 \mathrm{ml} \mathrm{F}, 5.2 \mathrm{ml} \mathrm{IP...}$ & 0 & $\mathbf{0}$ & 5 & $\mathbf{5}$ & 10 & 15 & 15 \\
\hline $0.4 \mathrm{ml} \mathrm{F}, 5.6 \mathrm{ml} \mathrm{IP....}$ & 0 & 0 & 5 & $\mathbf{5}$ & $\mathbf{5}$ & 10 & 10 \\
\hline $0.2 \mathrm{ml} \mathrm{F}, 5.8 \mathrm{ml} \mathrm{IP...}$ & 0 & 0 & 2 & 2 & 5 & 10 & 10 \\
\hline $0.1 \mathrm{ml} \mathrm{F}, 5.9 \mathrm{ml} \mathrm{IP....}$ & 0 & 0 & 1 & 1 & 5 & 10 & 10 \\
\hline $0.05 \mathrm{ml} \mathrm{F}, 5.95 \mathrm{ml} \mathrm{IP}$. & 0 & 0 & 1 & 1 & $\mathbf{5}$ & 10 & 10 \\
\hline \multicolumn{8}{|l|}{ E-1380 minus olefins: } \\
\hline $6 \mathrm{ml} \mathrm{F}, 0 \mathrm{ml} \mathrm{IP.....}$ & 0 & 10 & 20 & 30 & 50 & 75 & 95 \\
\hline $3 \mathrm{ml} \mathrm{F}, 3 \mathrm{ml} \mathrm{IP......}$ & 0 & $\mathbf{5}$ & 10 & 15 & 30 & 60 & 60 \\
\hline $1.5 \mathrm{ml} \mathrm{F}, 4.5 \mathrm{ml} \mathrm{IP.....}$ & 0 & 2 & $\mathbf{5}$ & 10 & 15 & 15 & 15 \\
\hline 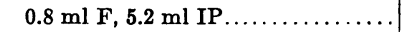 & 0 & 0 & 5 & 10 & 10 & 15 & 15 \\
\hline $0.4 \mathrm{ml} \mathrm{F}, 5.6 \mathrm{ml}$ IP. $\ldots \ldots \ldots \ldots \ldots$ & 0 & 0 & 2 & 5 & $\mathbf{5}$ & 10 & 15 \\
\hline $0.2 \mathrm{ml} \mathrm{F}, 5.8 \mathrm{ml} \mathrm{IP} \ldots \ldots \ldots \ldots \ldots \ldots$ & 0 & 0 & 1 & 2 & $\mathbf{5}$ & 10 & 15 \\
\hline $0.1 \mathrm{ml} \mathrm{F}, 5.9 \mathrm{ml} \mathrm{IP} \ldots \ldots \ldots \ldots \ldots$ & 0 & 0 & 1 & 1 & $\mathbf{5}$ & 10 & 10 \\
\hline $0.05 \mathrm{ml} \mathrm{F}, 5.95 \mathrm{ml} \mathrm{IP} \ldots \ldots \ldots \ldots \ldots$ & 0 & 0 & 1 & 1 & 5 & 10 & 10 \\
\hline \multicolumn{8}{|l|}{ E-1380 minus olefins and aromatics: } \\
\hline $6 \mathrm{ml} \mathrm{F}, 0 \mathrm{ml} \mathrm{IP} \ldots \ldots \ldots \ldots \ldots \ldots$ & 0 & 5 & 15 & 30 & 50 & 75 & 80 \\
\hline $3 \mathrm{ml} \mathrm{F}, 3 \mathrm{ml} \mathrm{IP} \ldots \ldots \ldots \ldots \ldots \ldots$ & 0 & $\mathbf{5}$ & 10 & 15 & 30 & 60 & 60 \\
\hline $1.5 \mathrm{ml} \mathrm{F}, 4.5 \mathrm{ml} \mathrm{IP} \ldots \ldots \ldots \ldots \ldots \ldots$ & 0 & 2 & 5 & 10 & 15 & 30 & 30 \\
\hline $0.8 \mathrm{ml} \mathrm{F}, 5.2 \mathrm{ml} \mathrm{IP} \ldots \ldots \ldots \ldots \ldots$ & 0 & 0 & 5 & 10 & 10 & 10 & 10 \\
\hline 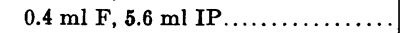 & 0 & 0 & 2 & 2 & 5 & 10 & 15 \\
\hline $0.2 \mathrm{ml} \mathrm{F}, 5.8 \mathrm{ml} \mathrm{IP} \ldots \ldots \ldots \ldots \ldots \ldots$ & 0 & 0 & 1 & 1 & $\mathbf{5}$ & 10 & 10 \\
\hline $0.1 \mathrm{ml} \mathrm{F}, 5.9 \mathrm{ml} \mathrm{IP} \ldots \ldots \ldots \ldots \ldots \ldots$ & 0 & 0 & 1 & 1 & $\mathbf{5}$ & 10 & 10 \\
\hline $0.05 \mathrm{ml} \mathrm{F}, 5.95 \mathrm{ml} \mathrm{IP} \ldots \ldots \ldots \ldots \ldots$ & 0 & 0 & 1 & 1 & 5 & 10 & 10 \\
\hline \multicolumn{8}{|l|}{ Isoparaffin alone: } \\
\hline $6 \mathrm{ml} \mathrm{IP,} \mathrm{first} \mathrm{check...............}$ & 0 & 0 & 1 & 1 & 5 & 10 & 10 \\
\hline $6 \mathrm{ml} \mathrm{IP}$, second check............ & 0 & 0 & 1 & 1 & 5 & 10 & 10 \\
\hline
\end{tabular}

residue, a partially refined product from the same source. Being coal-tar residues, these materials were highly aromatic and extremely toxic. Results of the tests (table 24) indicate a very interesting situation. By refinement this residue acquired chronic toxicity, so that it was still highly toxic at a dilution of 1 part in 128 after a 13-day observation period. Since this refined fraction lacked somewhat the acute toxicity of the crude residue, conceivably the refining had removed some of the lighter aromatics and thus had increased in concentration those heavier compounds responsible for chronic injury.

Olefinic and Aromatic Compounds. One experiment involved an attempt (1) to remove olefinic compounds from a straight-run gasoline; and (2) to 
remove both olefins and aromatic compounds. The methods of refinement involved use of acids of two concentrations and is based upon the assumption that olefins break down more readily than aromatics under acid treatment.

TABLE 26

Toxicity of Refined-Oil Separates to Grasses and Weeds;* NOVEMBER 11, 1944

\begin{tabular}{|c|c|c|c|c|c|c|c|c|}
\hline \multirow{3}{*}{ Oil fraction } & \multicolumn{8}{|c|}{ Injury to weeds (W) and grasses (G), in per cent } \\
\hline & \multicolumn{2}{|c|}{1 day } & \multicolumn{2}{|c|}{2 days } & \multicolumn{2}{|c|}{3 days } & \multicolumn{2}{|c|}{4 days } \\
\hline & W & G & W & G & W & G & $\mathbf{w}$ & $\mathbf{G}$ \\
\hline Heavy isoparaffin.......... & 0 & 0 & 0 & $\mathbf{0}$ & 0 & $\mathbf{0}$ & $\mathbf{0}$ & $\mathbf{0}$ \\
\hline Heavy naphthene.. & 10 & 20 & $\mathbf{0}$ & 0 & 0 & 0 & 0 & 0 \\
\hline Heavy olefins....... & 90 & 80 & 95 & 85 & 95 & 90 & 95 & 90 \\
\hline Heavy aromatics... & 95 & 95 & 98 & 98 & 100 & 100 & 100 & 100 \\
\hline Naphthone A ................ & 100 & 100 & 100 & 100 & 100 & 100 & 100 & 100 \\
\hline High-sulf ur gasoline . .......................... & 95 & 95 & 98 & 98 & 98 & 100 & 100 & 100 \\
\hline
\end{tabular}

- Weeds referred to here were Amsinckia, Lactuca, and Stellaria species.

TABLE 27

Toxicity of Refined-OIl Separates to Foxtail Sod; January 29, 1945

\begin{tabular}{|c|c|c|c|c|c|}
\hline \multirow{2}{*}{$\begin{array}{l}\text { Oil fraction and amounts of oil and diluent } \\
\text { (isoparaffin) applied per culture }\end{array}$} & \multicolumn{5}{|c|}{ Injury to plants, in per cent } \\
\hline & 1 day & 2 days & 4 days & 7 days & 11 days \\
\hline \multicolumn{6}{|l|}{ Heavy isoparaffin: } \\
\hline $6 \mathrm{ml} \mathrm{F}, 0 \mathrm{ml} \mathrm{IP} \ldots \ldots \ldots \ldots \ldots \ldots$ & 0 & 0 & 0 & 0 & 0 \\
\hline 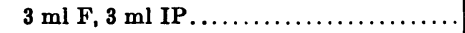 & $\mathbf{0}$ & 0 & $\mathbf{0}$ & 0 & $\mathbf{0}$ \\
\hline $11 / 2 \mathrm{ml} \mathrm{F}, 41 / 2 \mathrm{ml} \mathrm{IP} \ldots \ldots \ldots \ldots \ldots$ & 0 & $\mathbf{0}$ & 0 & 0 & $\mathbf{0}$ \\
\hline \multicolumn{6}{|l|}{ Heavy naphthene: } \\
\hline $6 \mathrm{ml} \mathrm{F}, 0 \mathrm{ml} \mathrm{IP...}$ & 25 & 25 & 25 & 35 & 20 \\
\hline $3 \mathrm{ml} \mathrm{F}, 3 \mathrm{ml} \mathrm{IP} \ldots \ldots \ldots \ldots \ldots \ldots \ldots$ & 10 & 10 & 10 & 10 & 5 \\
\hline $11 / 2 \mathrm{ml} \mathrm{F}, 41 / 2 \mathrm{ml} \mathrm{IP} \ldots \ldots \ldots \ldots \ldots \ldots$ & 0 & 0 & $\mathbf{5}$ & 5 & 5 \\
\hline \multicolumn{6}{|l|}{ Heavy olefin: } \\
\hline $6 \mathrm{ml} \mathrm{F}, 0 \mathrm{ml} \mathrm{IP} \ldots \ldots \ldots \ldots \ldots$ & 50 & 75 & 90 & 95 & 95 \\
\hline $3 \mathrm{ml} \mathrm{F}, 3 \mathrm{ml} \mathrm{IP} \ldots \ldots \ldots \ldots \ldots \ldots$ & 50 & 75 & 90 & 95 & 95 \\
\hline $11 / 2 \mathrm{ml} \mathrm{F}, 41 / 2 \mathrm{ml} \mathrm{IP} \ldots \ldots \ldots \ldots \ldots \ldots$ & 25 & 60 & 75 & 85 & 90 \\
\hline \multicolumn{6}{|l|}{ Heavy aromatic: } \\
\hline $6 \mathrm{ml} \mathrm{F}, 0 \mathrm{ml} \mathrm{IP} . \ldots \ldots \ldots$ & 95 & 95 & 100 & 100 & 100 \\
\hline $3 \mathrm{ml} \mathrm{F}, 3 \mathrm{ml} \mathrm{IP} \ldots \ldots \ldots \ldots \ldots \ldots \ldots \ldots$ & 90 & 95 & 100 & 100 & 100 \\
\hline $11 / 2 \mathrm{ml} \mathrm{F}, 41 / 2 \mathrm{ml} \mathrm{IP} \ldots \ldots \ldots \ldots \ldots \ldots \ldots$ & 90 & 95 & 100 & 100 & 100 \\
\hline \multicolumn{6}{|l|}{ Naphthone A: } \\
\hline $6 \mathrm{ml} \mathrm{F}, 0 \mathrm{ml} \mathrm{IP} \ldots \ldots \ldots \ldots \ldots \ldots$ & 100 & 100 & 100 & 100 & 100 \\
\hline 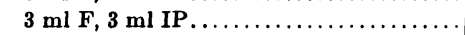 & 100 & 100 & 100 & 100 & 100 \\
\hline $11 / 2 \mathrm{ml} \mathrm{F}, 41 / 2 \mathrm{ml} \mathrm{IP} \ldots \ldots \ldots \ldots \ldots \ldots$ & 100 & 100 & 100 & 100 & 100 \\
\hline \multicolumn{6}{|l|}{ High-sulfur gasoline: } \\
\hline $6 \mathrm{ml} \mathrm{F}, 0 \mathrm{ml} \mathrm{IP.....}$ & 90 & 95 & 95 & 95 & 95 \\
\hline $3 \mathrm{ml} \mathrm{F}, 3 \mathrm{ml} \mathrm{IP} \ldots \ldots \ldots \ldots$ & 0 & 0 & 0 & $\mathbf{0}$ & $\mathbf{0}$ \\
\hline $11 / 2 \mathrm{ml} \mathrm{F}, 41 / 2 \mathrm{ml} \mathrm{IP} \ldots \ldots \ldots \ldots \ldots$ & $\mathbf{0}$ & 0 & 0 & 0 & 0 \\
\hline
\end{tabular}

Results, as shown in table 25 , indicate that the treatment probably removes most of the lighter compounds responsible for acute toxicity. The results of the second treatment, designed to remove aromatics plus olefins, are so nearly like those of the initial olefin-removing process that one doubts the effectiveness of this separation. 
A more accurate evaluation of the toxic properties of the various classes of compounds found in petroleum was attempted with fractions furnished by the Tidewater Associated Oil Company. These were all heavy fractions and were so prepared that each contained predominately one type of com-

TABLE 28

Toxicity of Heavy Aromatic and Olefinic Compounds to Carrots, Flax, Brassica, AND Grass; MaR.CH 19, 1945

\begin{tabular}{|c|c|c|c|c|c|c|c|c|c|c|c|c|}
\hline \multirow{3}{*}{$\begin{array}{l}\text { Type of fraction } \\
\text { and per cent } \\
\text { of fraction }(\mathrm{F}) \\
\text { and diluent } \\
\text { (isoparaffin)* }\end{array}$} & \multicolumn{12}{|c|}{ Injury to carrots (C), flax (F), Brassica (B), and grass (G), in per cent } \\
\hline & \multicolumn{4}{|c|}{1 day } & \multicolumn{4}{|c|}{2 days } & \multicolumn{4}{|c|}{3 days } \\
\hline & $\mathrm{C}$ & F & $\mathbf{B}$ & G & $\mathrm{C}$ & $\mathbf{F}$ & $\mathbf{B}$ & G & $\mathbf{C}$ & $\mathbf{F}$ & B & G \\
\hline Heavy olefin: & & & & & & & & & & & & \\
\hline $50 \% \mathrm{~F}, 50 \%$ IP. & 50 & 100 & 100 & 50 & 70 & 100 & 100 & 90 & 75 & 100 & 100 & 95 \\
\hline $45 \%$ F, $55 \%$ IP. & 45 & 100 & 100 & 40 & 50 & 100 & 100 & 90 & 50 & 100 & 100 & 85 \\
\hline $40 \% \mathrm{~F}, 60 \% \mathrm{IP}$. & 30 & 95 & 90 & 30 & 40 & 100 & 95 & 75 & 40 & 100 & 100 & 85 \\
\hline $35 \% \mathrm{~F}, 65 \%$ IP. & 20 & 90 & 80 & 30 & 20 & 100 & 85 & 60 & 20 & 100 & 95 & 75 \\
\hline $30 \% \mathrm{~F}, \mathbf{7 0} \%$ IP $\ldots$ & 10 & 20 & 80 & 20 & 10 & 60 & 80 & 40 & 10 & 80 & 95 & 60 \\
\hline \multicolumn{13}{|l|}{ Heavy aromatic: } \\
\hline $50 \% \mathrm{~F}, 50 \% \mathrm{IP}$. & 75 & 90 & 100 & 75 & 90 & 100 & 100 & 95 & 90 & 100 & 100 & 100 \\
\hline $45 \% \mathrm{~F}, 55 \%$ IP. & 50 & 100 & 100 & 60 & 75 & 100 & 100 & 95 & 75 & 100 & 100 & 100 \\
\hline $40 \% \mathrm{~F}, 60 \%$ IP... & 40 & 100 & 100 & 60 & 60 & 100 & 100 & 90 & 60 & 100 & 100 & 95 \\
\hline $30 \%$ F, $70 \%$ IP... & 10 & 100 & 90 & 60 & 30 & 100 & 100 & 90 & 30 & 100 & 98 & 95 \\
\hline $20 \% \mathrm{~F}, 80 \%$ IP... & 5 & 100 & 80 & 50 & 10 & 100 & 90 & 75 & 10 & 100 & 95 & 90 \\
\hline \multirow[t]{3}{*}{$10 \% \mathrm{~F}, 90 \%$ IP... } & 0 & 10 & 20 & 10 & 0 & 25 & 40 & 30 & 0 & 40 & 50 & 50 \\
\hline & \multicolumn{4}{|c|}{7 days } & \multicolumn{4}{|c|}{9 days } & \multicolumn{4}{|c|}{12 days } \\
\hline & $\mathrm{C}$ & $F$ & B & G & $\mathrm{C}$ & $\mathbf{F}$ & B & G & $\mathrm{C}$ & $\mathbf{F}$ & B & G \\
\hline \multicolumn{13}{|l|}{ Heavy olefin: } \\
\hline $50 \%$ F, $50 \%$ IP... & 50 & 99 & 100 & 98 & 50 & 98 & 100 & 99 & 30 & 95 & 100 & 100 \\
\hline $45 \% \mathrm{~F}, 55 \%$ IP... & 40 & 99 & 100 & 100 & 40 & 98 & 100 & 100 & 20 & 95 & 100 & 100 \\
\hline $40 \% \mathrm{~F}, 60 \% \mathrm{IP} \ldots$ & 30 & 99 & 100 & 95 & 30 & 98 & 100 & 95 & 15 & 95 & 100 & 95 \\
\hline $35 \% \mathrm{~F}, 65 \%$ IP... & 10 & 99 & 95 & 90 & $\mathbf{5}$ & 98 & 98 & 95 & 5 & 90 & 100 & 95 \\
\hline $30 \%$ F, $70 \%$ IP... & 5 & 95 & 95 & 85 & 0 & 75 & 98 & 90 & 0 & 75 & 100 & 95 \\
\hline \multicolumn{13}{|l|}{ Heavy aromatic: } \\
\hline $50 \%$ F, $50 \%$ IP $\ldots$ & 90 & 90 & 100 & 100 & 90 & 90 & 100 & 100 & 80 & 90 & 100 & 100 \\
\hline $45 \%$ F, $55 \%$ IP... & 80 & 99 & 100 & 100 & 80 & 98 & 100 & 100 & 70 & 95 & 100 & 100 \\
\hline $40 \% \mathrm{~F}, 60 \% \mathrm{IP} \ldots$ & 60 & 99 & 100 & 100 & 60 & 98 & 100 & 100 & 50 & 95 & 100 & 100 \\
\hline $30 \%$ F, $70 \%$ IP... & 20 & 99 & 100 & 100 & 20 & 98 & 100 & 100 & 10 & 95 & 100 & 100 \\
\hline $20 \%$ F, $80 \%$ IP... & 0 & 98 & 100 & 95 & 0 & 95 & 100 & 98 & 0 & 95 & 100 & 99 \\
\hline $10 \% \mathrm{~F}, 90 \% \mathrm{IP} .$. & 0 & 50 & 75 & 75 & 0 & 50 & 75 & 80 & 0 & 40 & 75 & 85 \\
\hline
\end{tabular}

* Total volume applied to each culture, $6 \mathrm{ml}$.

pound. Included were samples of isoparaffinic, naphthenic, aromatic, and olefinic compounds. Also tested was a fraction termed naphthone $\mathrm{A}$ and a sample of high-sulfur gasoline. Table 26 presents a preliminary test, and table 27 contains more detailed information.

Judging from these data, the isoparaffinic fraction was lacking in toxicity. This fraction was considerably heavier than the previously tested heavy isoparaffin submitted as a possible diluent. It appeared even heavier than the mineral seal oil. The naphthenic fraction, though toxic, did not carry the killing power to exterminate the grasses, which therefore eventually recovered. 


\section{TABLE 29}

Toxicity of Heavy Olefinic and Aromatic Fractions in $n$-Cetane to Carrots, Flax, AND Grass; APRIL 25, 1945

\begin{tabular}{|c|c|c|c|c|c|c|c|c|c|c|c|c|c|c|c|c|c|c|}
\hline \multirow{3}{*}{$\begin{array}{l}\text { Type of fraction and } \\
\text { per cent of fraction (F) } \\
\text { and diluent }(n \text {-cetane) }\end{array}$} & \multicolumn{18}{|c|}{ Injury to carrots $(\mathrm{C})$, flax $(\mathrm{F})$, and grass $(\mathrm{G})$, in per cent } \\
\hline & \multicolumn{3}{|c|}{1 day } & \multicolumn{3}{|c|}{2 days } & \multicolumn{3}{|c|}{3 days } & \multicolumn{3}{|c|}{4 days } & \multicolumn{3}{|c|}{6 days } & \multicolumn{3}{|c|}{8 days } \\
\hline & $\mathrm{C}$ & $\mathbf{F}$ & G & $\mathbf{C}$ & $\mathbf{F}$ & G & C & $\mathrm{F}$ & $\mathrm{G}$ & $\mathbf{C}$ & $\mathbf{F}$ & G & $\mathrm{C}$ & $\mathbf{F}$ & G & $\mathbf{C}$ & $\mathrm{F}$ & G \\
\hline \multicolumn{19}{|l|}{ Heavy olefin: } \\
\hline $50 \% \mathrm{~F}, 50 \% \mathrm{C} \ldots$ & $\mathbf{5}$ & 20 & 50 & 10 & 40 & 75 & 10 & 50 & 85 & 20 & 80 & 98 & 20 & 90 & 100 & 10 & 95 & 100 \\
\hline $45 \%$ F, $55 \%$ C... & 5 & 10 & 30 & 10 & 30 & 60 & 20 & 40 & 70 & 20 & 60 & 70 & 20 & 75 & 80 & 15 & 90 & 90 \\
\hline $40 \% \mathrm{~F}, 60 \% \mathrm{C} \ldots$ & 0 & 5 & 20 & $\mathbf{5}$ & 15 & 40 & 5 & 20 & 60 & 10 & 50 & 50 & 10 & 65 & 75 & 10 & 75 & 80 \\
\hline $35 \% \mathrm{~F}, 65 \% \mathrm{C} \ldots$ & 0 & 0 & 10 & 0 & 5 & 20 & 0 & 10 & 30 & $\mathbf{5}$ & 25 & 20 & 0 & 35 & 30 & 0 & 40 & 40 \\
\hline $30 \% \mathrm{~F}, 70 \% \mathrm{C}$. & 0 & 0 & 5 & 0 & 0 & 10 & 0 & 2 & 20 & 0 & $\mathbf{5}$ & 20 & 0 & 10 & 25 & 0 & 10 & 20 \\
\hline $25 \%$ F, $75 \%$ C.. & 0 & 0 & 0 & 0 & 0 & $\mathbf{5}$ & 0 & 1 & 10 & 0 & 5 & 10 & 0 & 5 & 15 & 0 & 5 & 10 \\
\hline \multicolumn{19}{|l|}{ Heavy aromatic: } \\
\hline $40 \% \mathrm{~F}, 60 \% \mathrm{C}$. & 5 & 50 & 50 & 10 & 75 & 75 & 10 & 85 & 90 & 10 & 95 & 100 & 15 & 95 & 100 & 15 & 95 & 100 \\
\hline $35 \% \mathrm{~F}, 65 \% \mathrm{C}$. & 0 & 5 & 60 & 5 & 10 & 90 & 5 & 25 & 90 & 5 & 75 & 100 & $\mathbf{5}$ & 80 & 100 & 5 & 80 & 100 \\
\hline $30 \% \mathrm{~F}, 70 \% \mathrm{C}$. & $\mathbf{0}$ & 0 & 30 & 5 & $\mathbf{5}$ & 60 & 0 & 15 & 60 & 0 & 50 & 80 & 0 & 70 & 90 & 0 & 70 & 95 \\
\hline $25 \% \mathrm{~F}, 75 \% \mathrm{C}$. & 0 & 0 & 15 & 0 & 5 & 30 & 0 & 10 & 40 & 0 & 25 & 40 & 0 & 50 & 75 & 0 & 60 & 80 \\
\hline $20 \% \mathrm{~F}, 80 \% \mathrm{C}$. & 0 & 0 & 10 & 0 & 2 & 20 & 0 & $\mathbf{5}$ & 25 & 0 & 15 & 25 & 0 & 20 & 50 & 0 & 20 & 60 \\
\hline $15 \% \mathrm{~F}, 85 \% \mathrm{C}$. & 0 & 0 & $\mathbf{5}$ & 0 & 0 & 10 & 0 & 0 & 15 & 0 & 0 & 15 & 0 & 0 & 20 & 0 & 0 & 20 \\
\hline $10 \% \mathrm{~F}, 90 \% \mathrm{C}$. & 0 & 0 & 0 & 0 & 0 & 5 & 0 & 0 & $\mathbf{5}$ & 0 & 0 & $\mathbf{5}$ & 0 & 0 & 0 & 0 & 0 & 0 \\
\hline $0 \% \mathrm{~F}, 100 \% \mathrm{C} \ldots$ & 0 & 0 & 0 & 0 & 0 & 0 & 0 & 0 & 0 & 0 & 0 & 0 & 0 & 0 & 0 & 0 & 0 & 0 \\
\hline Mineral seal oil, $100 \% \ldots$ & 0 & 0 & 0 & 0 & 0 & 0 & 5 & 0 & 0 & 5 & 0 & 0 & 0 & 10 & 0 & 0 & 15 & 5 \\
\hline Odorless kerosene, $100 \%$. & 0 & 0 & 0 & 0 & 0 & 0 & 0 & 0 & $\mathbf{5}$ & 0 & 0 & 25 & 0 & 0 & 50 & 0 & 0 & 50 \\
\hline Kerosene, $100 \% \ldots \ldots \ldots \ldots$ & 0 & 0 & 0 & 0 & 0 & 0 & 0 & 0 & 0 & 5 & 0 & 10 & 0 & 0 & 0 & 0 & 0 & 0 \\
\hline \multirow[t]{3}{*}{ Isoparaffin, $100 \% \ldots \ldots \ldots$} & 0 & 0 & 0 & 0 & 0 & 0 & 0 & 0 & 0 & 0 & 0 & 0 & 0 & 0 & 0 & 0 & 0 & 0 \\
\hline & \multicolumn{3}{|c|}{10 days } & \multicolumn{3}{|c|}{12 days } & \multicolumn{3}{|c|}{16 days } & \multicolumn{3}{|c|}{19 days } & \multicolumn{3}{|c|}{22 days } & & & \\
\hline & $\mathrm{C}$ & $\mathrm{F}$ & G & $\mathrm{C}$ & $\mathbf{F}$ & G & $\mathrm{C}$ & $\mathbf{F}$ & G & $\mathrm{C}$ & $\mathbf{F}$ & G & C & $\mathbf{F}$ & G & & & \\
\hline \multicolumn{19}{|l|}{ Heavy olefin: } \\
\hline $50 \% \mathrm{~F}, \mathbf{5 0} \% \mathrm{C}$ & 10 & 95 & 100 & 15 & 95 & 100 & 15 & 95 & 100 & 10 & 90 & 100 & 10 & 75 & 100 & & & \\
\hline $45 \% \mathrm{~F}, 55 \% \mathrm{C}$. & 15 & 90 & 95 & 15 & 90 & 95 & 10 & 90 & 100 & 5 & 80 & 100 & $\mathbf{5}$ & 75 & 100 & & & \\
\hline $40 \% \mathrm{~F}, 60 \% \mathrm{C}$. & 10 & 80 & 85 & 15 & 80 & 90 & 10 & 80 & 95 & 5 & 70 & 100 & 5 & 70 & 100 & & & \\
\hline $35 \% \mathrm{~F}, 65 \% \mathrm{C}$. & 0 & 50 & 75 & 5 & 60 & 80 & 0 & 60 & 90 & 0 & 50 & 100 & 0 & 50 & 100 & & & \\
\hline $30 \% \mathrm{~F}, 70 \% \mathrm{C}$. & 0 & 15 & 20 & 0 & 20 & 20 & 0 & 15 & 40 & 0 & 10 & 75 & 0 & 10 & 75 & & & \\
\hline $25 \%$ F, $75 \%$ C... & 0 & 5 & 10 & 0 & $\mathbf{5}$ & 10 & 0 & 0 & 20 & 0 & 0 & 40 & 0 & 0 & 50 & & & \\
\hline Heavy aromatic: & & & & & & & & & & & & & & & & & & \\
\hline $40 \% \mathrm{~F}, 60 \% \mathrm{C}$. & 15 & 95 & 100 & 10 & 95 & 100 & 10 & 95 & 100 & 5 & 90 & 100 & 0 & 85 & 100 & & & \\
\hline $35 \% \mathrm{~F}, 65 \% \mathrm{C}$. & $\mathbf{5}$ & 80 & 100 & 5 & 80 & 100 & 5 & 90 & 100 & 0 & 90 & 100 & 0 & 90 & 100 & & & \\
\hline $30 \% \mathrm{~F}, 70 \% \mathrm{C} \ldots$ & 0 & 70 & 95 & 5 & 70 & 100 & 5 & 75 & 100 & 0 & 75 & 100 & 0 & 75 & 100 & & & \\
\hline $25 \% \mathrm{~F}, 75 \% \mathrm{C} \ldots$ & 0 & 60 & 85 & 0 & 60 & 90 & 0 & 60 & 90 & 0 & 60 & 95 & 0 & 60 & 100 & & & \\
\hline $20 \% \mathrm{~F}, 80 \% \mathrm{C} \ldots$ & 0 & 20 & 75 & 0 & 25 & 80 & 0 & 25 & 80 & 0 & 25 & 50 & 0 & 25 & 60 & & & \\
\hline $15 \% \mathrm{~F}, 85 \% \mathrm{C} \ldots$ & 0 & 0 & 40 & 0 & 5 & 40 & 0 & 0 & 40 & 0 & 0 & 20 & 0 & 0 & 30 & & & \\
\hline $10 \% \mathrm{~F}, 90 \% \mathrm{C} \ldots$ & 0 & 0 & 0 & 0 & 0 & 0 & 0 & 0 & $\mathbf{0}$ & 0 & 0 & 0 & 0 & 0 & 0 & & & \\
\hline $0 \% \mathrm{~F}, 100 \% \mathrm{C} \ldots$ & 0 & 0 & 0 & 0 & 0 & 0 & 0 & 0 & 0 & 0 & 0 & 0 & 0 & 0 & 0 & & & \\
\hline Mineral seal oil, $100 \% \ldots \ldots$ & 0 & 15 & 10 & 0 & 15 & 20 & 0 & 10 & 50 & 0 & 10 & 75 & 0 & 10 & 90 & & & \\
\hline Odorless kerosene, $100 \% \ldots$ & 0 & 0 & 75 & 0 & $\mathbf{5}$ & 90 & 0 & $\mathbf{5}$ & 100 & 0 & 0 & 100 & 0 & 0 & 100 & & & \\
\hline Kerosene, $100 \% \ldots \ldots \ldots \ldots$ & 0 & $\mathbf{0}$ & 0 & 0 & 0 & 10 & 0 & 0 & 10 & 0 & 0 & 20 & 0 & 0 & 20 & & & \\
\hline Isoparaffin, $100 \% \ldots \ldots \ldots \ldots$ & 0 & 0 & 0 & 0 & 0 & 0 & 0 & 0 & 0 & 0 & 0 & 0 & 0 & 0 & 0 & & & \\
\hline
\end{tabular}

- Total volume applied to each culture, $6 \mathrm{ml}$. 
The olefinic fraction was highly toxic but, like the naphthenic, lacked the power to exterminate the grasses. The aromatic fraction was very effective, and the grass cultures succumbed to its application.

The naphthone A was an odd-smelling oil of extreme toxicity. It wilted and discolored the plants rapidly after application; they all died within one day.

The high-sulfur gasoline also was toxic at full strength, but proved low in toxicity when diluted.

Because the heavy olefinic and heavy aromatic fractions seem to offer the most promise as selective toxicants, concentration series using the isoparaffin fraction as a diluent were sprayed on carrots, flax, mustard, and foxtail. Results are shown in table 28.

The aromatic fraction is somewhat more toxic than the olefinic. Both are highly selective as between carrots and other weeds. The margin of selectivity for flax is much narrower, but still may be sufficient to be of practical use.

Because the heavy isoparaffinic material used as a diluent in these experiments had a slightly chronic toxicity that began to show up after about 2 weeks, the experiment was repeated with normal cetane, a relatively nontoxic diluent. Table 29 gives these results with readings over a 22 -day period. Mineral seal oil, an old sample of odorless kerosene, a fresh lot of ordinary kerosene, and a fresh sample of isoparaffin were tested as standards for comparative evaluation of toxicity. The isoparaffin and normal cetane both proved nontoxic in the tests.

These results show conclusively that the aromatic compounds are more toxic than the olefinic, if the samples used were of comparable purity. Furthermore, the aromatic fraction appears to have been somewhat more selective than the olefinic. Carrots completely recovered from the toxic effects of the higher concentrations of aromatic compounds. They showed some recovery from olefin toxicity, but not complete.

One interesting observation is the extreme effectiveness on grass of the compounds responsible for toxicity in the stale, odorless kerosene fraction. Apparently these can have constituted only a small fraction of the total makeup of the oil; yet they killed the foxtail, a result which in other tests required 25 per cent of aromatics and 35 per cent of olefinic compounds.

\section{RELATION OF TOXICITY TO BOILING RANGE IN EDELEANU EXTRACT}

Toxicity of Badger-Type Distillate Cuts. According to data cited in the preceding section, successive extracts by solvent extraction decreased in toxicity, and the final raffinate was relatively nontoxic. Another point of interest is the comparative toxicity of different temperature cuts of the Edeleanu extract. ${ }^{\circ}$ Ten Badger-type distillation cuts were tested on grass and carrot cultures. Table 30 presents the results of tests using the cuts pure on carrots and in dilutions of $1: 3$ and $1: 7$ on grass. Odorless kerosene, which was fresh at the time of these tests, was used as a diluent.

\footnotetext{
- The Edeleanu process is the refining of oil by means of liquid sulfur dioxide to remove unsaturates.
} 
TABLE 30

Toxicity of Badger-type Distillation Cuts of Edeleanu Extract on Grass aND CARRots; JaNUARY 15, 1944

\begin{tabular}{|c|c|c|c|c|c|c|c|c|c|c|c|c|c|c|c|}
\hline \multirow{3}{*}{$\begin{array}{c}\text { BTD } \\
\text { cut no. }\end{array}$} & \multirow{2}{*}{\multicolumn{5}{|c|}{$\frac{\text { Injury to carrots, in per cent }}{\text { Pure cuts }}$}} & \multicolumn{10}{|c|}{ Injury to grass, in per cent } \\
\hline & & & & & & \multicolumn{5}{|c|}{ With 2 parts BTD : 6 parts OK* } & \multicolumn{5}{|c|}{ With 1 part BTD : 7 parts OK } \\
\hline & $\begin{array}{c}1 \\
\text { day }\end{array}$ & $\stackrel{2}{\text { days }}$ & $\begin{array}{c}3 \\
\text { days }\end{array}$ & $\begin{array}{c}5 \\
\text { days }\end{array}$ & $\begin{array}{c}10 \\
\text { days }\end{array}$ & $\begin{array}{c}1 \\
\text { day }\end{array}$ & $\stackrel{2}{\text { days }}$ & $\begin{array}{c}3 \\
\text { days }\end{array}$ & $\begin{array}{c}5 \\
\text { days }\end{array}$ & $\begin{array}{c}10 \\
\text { days }\end{array}$ & $\begin{array}{c}1 \\
\text { day }\end{array}$ & $\stackrel{2}{\text { days }}$ & $\begin{array}{c}3 \\
\text { days }\end{array}$ & $\begin{array}{c}5 \\
\text { days }\end{array}$ & $\begin{array}{c}10 \\
\text { days }\end{array}$ \\
\hline No. $1 .$. & 50 & 50 & 50 & 50 & 50 & 80 & 90 & 95 & 95 & 100 & 10 & 30 & 40 & 40 & 95 \\
\hline No. 2. & 50 & 50 & 60 & 50 & 50 & 75 & 80 & 90 & 90 & 95 & 60 & 75 & 60 & 75 & 100 \\
\hline No. $3 .$. & 75 & 75 & 80 & 85 & 90 & 95 & 100 & 100 & 100 & 100 & 75 & 85 & 80 & 95 & 100 \\
\hline No. $4 .$. & 90 & gn & 100 & 100 & 100 & 100 & 100 & 100 & 100 & 100 & 85 & 95 & 90 & 95 & 100 \\
\hline No. 5. & 80 & 90 & 90 & 95 & 95 & 90 & 100 & 100 & 100 & 100 & 60 & 75 & 80 & 95 & 100 \\
\hline No. $6 .$. & 50 & 75 & 80 & 85 & 75 & 95 & 100 & 100 & 100 & 100 & 60 & 90 & 90 & 95 & 95 \\
\hline No. $7 \ldots$ & 40 & 50 & 60 & $\mathbf{7 5}$ & 90 & 100 & 100 & 100 & 100 & 100 & 75 & 90 & 95 & 100 & 100 \\
\hline No. $8 . .$. & 90 & 95 & 100 & 100 & 100 & 90 & 100 & 100 & 100 & 100 & 60 & 90 & 98 & 100 & 100 \\
\hline No. $9 .$. & 95 & 95 & 100 & 100 & 100 & 100 & 100 & 100 & 100 & 100 & 75 & 90 & 95 & 100 & 100 \\
\hline No. $10 \ldots$ & 60 & 90 & 100 & 100 & 100 & 90 & 100 & 100 & 100 & 100 & 80 & 98 & 100 & 100 & 100 \\
\hline
\end{tabular}

* Odorless kerosene.

TABLE 31

Toxicity of Fractional Distillates of E-1296 as Shown by Carrots, Chenopodium murale, Malva parviflora, AND GRASS ; FeBRUARY 11, 1944

\begin{tabular}{|c|c|c|c|c|c|c|c|c|c|c|c|c|}
\hline \multirow{3}{*}{$\begin{array}{c}\text { Fraction no. and amounts of } \\
\text { fraction (F) and diluent } \\
\text { (odorless kerosene) applied } \\
\text { per culture }\end{array}$} & \multicolumn{12}{|c|}{$\begin{array}{c}\text { Injury to carrots }(\mathrm{C}), \text { Chenopodium murale }(\mathrm{Cm}), \text { Malva parviflora }(\mathrm{M}) \text {, and } \\
\text { grass }(\mathrm{G}), \text { in per cent }\end{array}$} \\
\hline & \multicolumn{4}{|c|}{1 day } & \multicolumn{4}{|c|}{4 days } & \multicolumn{4}{|c|}{9 days } \\
\hline & C & $\mathrm{Cm}$ & $\mathbf{M}$ & G & C & $\mathrm{Cm}$ & $\mathbf{M}$ & G & $\mathrm{C}$ & $\mathrm{Cm}$ & $\mathbf{M}$ & G \\
\hline No. 1: & & & & & & & & & & & & \\
\hline $2 \mathrm{ml} \mathrm{F}, 6 \mathrm{ml} \mathrm{OK} \ldots$ & 0 & 50 & 75 & 10 & $\mathbf{0}$ & 95 & 85 & 10 & 0 & 100 & 75 & 5 \\
\hline $1 \mathrm{ml} \mathrm{F}, 7 \mathrm{ml} \mathrm{OK} . .$. & 0 & 5 & $\mathbf{5}$ & 0 & $\mathbf{0}$ & 15 & 10 & 0 & 0 & 20 & $\mathbf{5}$ & 0 \\
\hline $1 / 2 \mathrm{ml} \mathrm{F}, 71 / 2 \mathrm{ml} \mathrm{OK}$. & 0 & 0 & $\mathbf{0}$ & 0 & 0 & 0 & 0 & 0 & 0 & 0 & 0 & 0 \\
\hline $1 / 4 \mathrm{ml} \mathrm{F}, 73 / 4 \mathrm{ml} \mathrm{OK} .$. & 0 & 0 & 0 & 0 & 0 & 0 & 0 & 0 & 0 & 0 & 0 & 0 \\
\hline No. 2: & & & & & & & & & & & & \\
\hline $2 \mathrm{ml} \mathrm{F}, 6 \mathrm{ml} \mathrm{OK} .$. & 0 & 75 & 90 & 25 & $\mathbf{0}$ & 95 & 95 & 35 & 0 & 100 & 95 & 50 \\
\hline $1 \mathrm{ml} \mathrm{F}, 7 \mathrm{ml} \mathrm{OK} . .$. & 0 & 50 & 50 & 0 & $\mathbf{0}$ & 75 & 75 & $\mathbf{5}$ & 0 & 95 & 60 & 15 \\
\hline $1 / 2 \mathrm{ml} \mathrm{F}, 71 / 2 \mathrm{ml} \mathrm{OK} \ldots \ldots$ & 0 & $\mathbf{0}$ & 0 & $\mathbf{0}$ & 0 & $\mathbf{5}$ & 0 & 0 & 0 & 10 & 0 & $\mathbf{0}$ \\
\hline $1 / 4 \mathrm{ml} \mathrm{F}, 73 / 4 \mathrm{ml} \mathrm{OK} \ldots \ldots \ldots$ & 0 & 0 & 0 & $\mathbf{0}$ & $\mathbf{0}$ & 0 & 0 & $\mathbf{0}$ & 0 & 0 & $\mathbf{0}$ & $\mathbf{0}$ \\
\hline No. 3: & & & & & & & & & & & & \\
\hline $2 \mathrm{ml} \mathrm{F}, 6 \mathrm{ml} \mathrm{OK} .$. & 0 & 90 & 90 & 50 & $\mathbf{0}$ & 100 & 95 & 75 & 0 & 100 & 95 & 95 \\
\hline $1 \mathrm{ml} \mathrm{F}, 7 \mathrm{ml} \mathrm{OK} . . . .$. & $\mathbf{0}$ & 75 & 75 & 0 & $\mathbf{0}$ & 95 & 85 & 10 & 0 & 100 & 65 & 10 \\
\hline $1 / 2 \mathrm{ml} \mathrm{F}, 71 / 2 \mathrm{ml} \mathrm{OK} . . .$. & $\mathbf{0}$ & 25 & 20 & 0 & 0 & 40 & 30 & 0 & $\mathbf{0}$ & 50 & 10 & 0 \\
\hline $1 / 4 \mathrm{ml} \mathrm{F}, 78 / 4 \mathrm{ml} \mathrm{OK} \ldots \ldots \ldots \ldots$ & 0 & 0 & 0 & 0 & 0 & $\mathbf{5}$ & $\mathbf{0}$ & $\mathbf{0}$ & 0 & $\mathbf{5}$ & $\mathbf{0}$ & 0 \\
\hline No. 4: & & & & & & & & & & & & \\
\hline $2 \mathrm{ml} \mathrm{F}, 6 \mathrm{ml} \mathrm{OK} . .$. & 5 & 95 & 95 & 80 & $\mathbf{5}$ & 100 & 100 & 80 & 0 & 100 & 100 & 90 \\
\hline $1 \mathrm{ml} \mathrm{F}, 7 \mathrm{ml} \mathrm{OK} . . . .$. & 0 & 75 & 75 & 10 & 0 & 100 & 90 & 10 & 0 & 90 & 95 & 50 \\
\hline $1 / 2 \mathrm{ml} \mathrm{F}, 71 / 2 \mathrm{ml} \mathrm{OK} . . .$. & 0 & 50 & 20 & 0 & 0 & 95 & 30 & 0 & 0 & 100 & 40 & 5 \\
\hline $1 / 4 \mathrm{ml} \mathrm{F}, 78 / 4 \mathrm{ml} \mathrm{OK} . .$. & $\mathbf{0}$ & 10 & 0 & 0 & 0 & 40 & $\mathbf{0}$ & 0 & 0 & 20 & 0 & 0 \\
\hline No. 5 : & & & & & & & & & & & & \\
\hline $2 \mathrm{ml} \mathrm{F}, 6 \mathrm{ml} \mathrm{OK}$ & 10 & 95 & 95 & 90 & 20 & 100 & 100 & 100 & 10 & 100 & 100 & 100 \\
\hline $1 \mathrm{ml} \mathrm{F}, 7 \mathrm{ml} \mathrm{OK} \ldots$ & $\mathbf{0}$ & 90 & 90 & 50 & $\mathbf{0}$ & 100 & 100 & 50 & $\mathbf{5}$ & 100 & 100 & 75 \\
\hline $1 / 2 \mathrm{ml} \mathrm{F}, 71 / 2 \mathrm{ml} \mathrm{OK} \ldots \ldots$ & $\mathbf{0}$ & 60 & 30 & 0 & 0 & 100 & 50 & $\mathbf{5}$ & 0 & 100 & 50 & 10 \\
\hline $1 / 4 \mathrm{ml} \mathrm{F}, 78 / 4 \mathrm{ml} \mathrm{OK} \ldots \ldots \ldots$ & $\mathbf{0}$ & 20 & 0 & 0 & $\mathbf{0}$ & $\mathbf{7 5}$ & 0 & 0 & 0 & 100 & 0 & $\mathbf{0}$ \\
\hline
\end{tabular}


Evidently toxicity increases with increasing weight of the cut, the heavy end being the most toxic. Boiling temperatures and gravities are shown below.

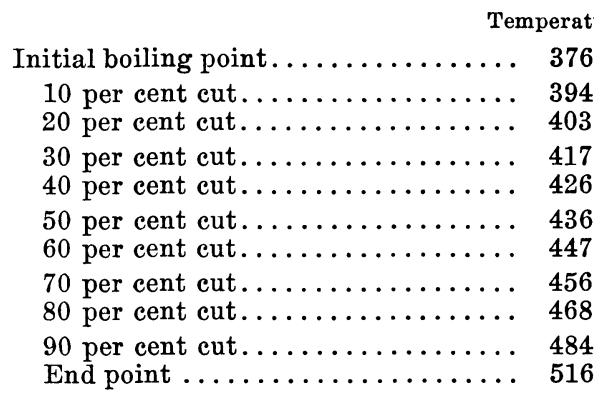

Gravity, ${ }^{\circ}$ A.P.I.

This extract was made from kerosene distillate. The four lightest fractions were within the gravity range of Diesel oil; the remaining six were heavier. These heavy oils were highly toxic and caused complete death of carrots when used pure. At a dilution of 1:7 in kerosene they caused no injury to carrots.

Some further experiments were performed on temperature cuts of Edeleanu extracts. Table 31 presents results on five fractions of E-1296, separated by ordinary distillation, applied to cultures of carrots, goosefoot, cheeseweed, and grass. These results confirm those of table 30 and illustrate the highly selective nature of the compounds present in the extract.

TABLE 32

Toxicity of Four Temperature Cuts of Avon Weed Killer to Carrots aNd BARLeY; May 5, 1944

\begin{tabular}{|c|c|c|c|c|c|c|c|c|}
\hline \multirow{2}{*}{$\begin{array}{l}\text { Avon fraction and amounts of fraction } \\
\text { (F) and diluent (isoparaffin) } \\
\text { applied per culture }\end{array}$} & \multirow{2}{*}{ Plant } & \multicolumn{7}{|c|}{ Injury to carrots or barley, in per cent } \\
\hline & & 1 day & 3 days & 5 days & 7 days & 10 days & 13 days & 15 days \\
\hline \multicolumn{9}{|l|}{ Avon no. 1: } \\
\hline $10 \mathrm{ml} \mathrm{F}, 0 \mathrm{ml} \mathrm{IP..}$ & Carrot & 90 & 95 & 98 & 98 & 100 & 100 & 100 \\
\hline $5 \mathrm{ml} \mathrm{F}, 5 \mathrm{ml} \mathrm{IP........}$ & Carrot & 30 & 40 & 40 & 30 & 30 & 30 & 40 \\
\hline 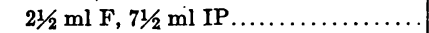 & Carrot & 10 & $\mathbf{5}$ & $\mathbf{5}$ & $\mathbf{5}$ & $\mathbf{5}$ & $\mathbf{5}$ & 10 \\
\hline $11 / 4 \mathrm{ml} \mathrm{F}, 83 / 4 \mathrm{ml} \mathrm{IP....}$ & Carrot & 0 & 0 & 0 & 0 & 0 & 0 & 0 \\
\hline $11 / 4 \mathrm{ml} \mathrm{F}, 8 \mathrm{~s} / \mathrm{ml} \mathrm{IP} \ldots \ldots \ldots \ldots \ldots$ & Barley & 30 & 30 & 30 & 30 & 30 & 40 & 40 \\
\hline \multicolumn{9}{|l|}{ Avon no. 2: } \\
\hline 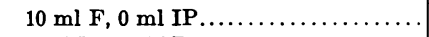 & Carrot & 90 & 90 & 95 & 98 & 100 & 100 & 100 \\
\hline $5 \mathrm{ml} \mathrm{F}, 5 \mathrm{ml} \mathrm{IP} \ldots \ldots \ldots \ldots \ldots \ldots \ldots$ & Carrot & 40 & 50 & 50 & 60 & 60 & 60 & 60 \\
\hline $21 / 2 \mathrm{ml} \mathrm{F}, 71 / 2 \mathrm{ml} \mathrm{IP} \ldots \ldots \ldots \ldots \ldots \ldots$ & Carrot & 10 & 10 & 10 & 10 & 10 & 10 & 15 \\
\hline $11 / 4 \mathrm{ml} \mathrm{F}, 88 / 4 \mathrm{ml} \mathrm{IP} \ldots \ldots \ldots \ldots \ldots \ldots$ & Carrot & 0 & 0 & 0 & 0 & 0 & 0 & 0 \\
\hline $11 / 4 \mathrm{ml} \mathrm{F}, 83 / 4 \mathrm{ml} \mathrm{IP.....................}$ & Barley & 40 & 60 & 60 & 60 & 60 & 75 & 75 \\
\hline \multicolumn{9}{|l|}{ Avon no. 3: } \\
\hline $10 \mathrm{ml} \mathrm{F}, 0 \mathrm{ml} \mathrm{IP...}$ & Carrot & 95 & 95 & 98 & 100 & 100 & 100 & 100 \\
\hline $5 \mathrm{ml} \mathrm{F}, 5 \mathrm{ml} \mathrm{lP} \ldots \ldots$. & Carrot & 50 & 50 & 90 & 60 & 70 & 70 & 70 \\
\hline $21 / 2 \mathrm{ml} \mathrm{F}, 71 / 2 \mathrm{ml} \mathrm{IP} \ldots \ldots \ldots \ldots$ & Carrot & 10 & 10 & 10 & 10 & 15 & 20 & 20 \\
\hline $11 / 4 \mathrm{ml} \mathrm{F}, 83 / 4 \mathrm{ml} \mathrm{IP} \ldots \ldots \ldots \ldots$ & Carrot & 0 & 0 & 0 & 0 & 0 & 0 & 0 \\
\hline $11 / 4 \mathrm{ml} \mathrm{F}, 88 / 4 \mathrm{ml} \mathrm{IP} \ldots \ldots \ldots \ldots$ & Barley & 50 & 75 & 85 & 90 & 95 & 100 & 100 \\
\hline \multicolumn{9}{|l|}{ Avon no. 4: } \\
\hline $10 \mathrm{ml} \mathrm{F}, 0 \mathrm{ml} \mathrm{IP} \ldots \ldots \ldots \ldots \ldots \ldots$ & Carrot & 90 & 95 & 95 & 95 & 100 & 100 & 100 \\
\hline 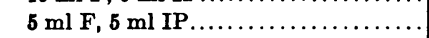 & Carrot & 60 & 60 & 60 & 60 & 70 & 75 & 75 \\
\hline $21 / 2 \mathrm{ml} \mathrm{F}, 71 / 2 \mathrm{ml} \mathrm{IP} \ldots \ldots \ldots \ldots \ldots$ & Carrot & 10 & 15 & 15 & 15 & 25 & 40 & 40 \\
\hline $11 / 4 \mathrm{ml} \mathrm{F}, 88 / 4 \mathrm{ml} \mathrm{IP} \ldots \ldots \ldots \ldots \ldots \ldots$ & Carrot & $\mathbf{0}$ & 0 & 0 & 0 & 10 & 15 & 20 \\
\hline $11 / 4 \mathrm{ml} \mathrm{F}, 88 / 4 \mathrm{ml} \mathrm{IP} \ldots \ldots \ldots \ldots \ldots \ldots$ & Barley & 90 & 100 & 100 & 100 & 100 & 100 & 100 \\
\hline
\end{tabular}


Temperature Cuts of Avon Weed Killer. Avon Weed Killer, an even heavier material, was cut into four fractions by distillation. These fractions were applied to carrots and barley as reported in table 32. Here, again, the heavier compounds were the more toxic. Evidently the heavy olefinic and aromatic compounds of petroleum are extremely toxic to plants; furthermore, they

TABLE 33

Toxicity of Four Temperature Cuts of Kerosene Extract (E-1296) on Barley and CHICKWEED; TWo CUTS WERE REFLUXED WITH AND WITHOUT THE

Presence of AIR; June 20, 1944

\begin{tabular}{|c|c|c|c|c|c|c|c|}
\hline \multirow{2}{*}{$\begin{array}{l}\text { E-1296 cut and amounts of cut (F) } \\
\text { and diluent (isoparaffin) } \\
\text { applied per culture }\end{array}$} & \multicolumn{7}{|c|}{ Injury to barley and chickweed, in per cent } \\
\hline & 1 day & 2 days & 3 days & 4 days & 5 days & 6 days & 8 days \\
\hline \multicolumn{8}{|l|}{ No. 1: } \\
\hline $6 \mathrm{ml} \mathrm{F}, 6 \mathrm{ml} \mathrm{IP.......}$ & 50 & 60 & 75 & 80 & 85 & 85 & 85 \\
\hline $3 \mathrm{ml} \mathrm{F,} 9 \mathrm{ml} \mathrm{IP............}$ & 25 & 30 & 50 & 60 & 70 & 70 & 70 \\
\hline $11 / 2 \mathrm{ml} \mathrm{F}, 101 / 2 \mathrm{ml} \mathrm{IP........}$ & $\mathbf{5}$ & 10 & 10 & 10 & 15 & 15 & 15 \\
\hline \multicolumn{8}{|l|}{ No. 2: } \\
\hline $6 \mathrm{ml} \mathrm{F}, 6 \mathrm{ml} \mathrm{IP.......}$ & 60 & 70 & 85 & 90 & 90 & 90 & 90 \\
\hline $3 \mathrm{ml} \mathrm{F}, 9 \mathrm{ml} \mathrm{IP} \ldots \ldots \ldots \ldots \ldots$ & 30 & 50 & 60 & 70 & 70 & 70 & 70 \\
\hline $11 / 2 \mathrm{ml} \mathrm{F}, 101 / 2 \mathrm{ml}$ IP............... & 10 & 15 & 10 & 10 & 15 & 15 & 15 \\
\hline \multicolumn{8}{|l|}{ No. 3: } \\
\hline $6 \mathrm{ml} \mathrm{F}, 6 \mathrm{ml} \mathrm{IP} \ldots \ldots \ldots \ldots \ldots \ldots \ldots$ & 70 & 80 & 95 & 95 & 95 & 95 & 100 \\
\hline 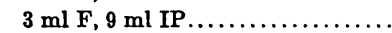 & 35 & 60 & 70 & 80 & 85 & 85 & 90 \\
\hline $11 / 2 \mathrm{ml} \mathrm{F}, 101 / 2 \mathrm{ml} \mathrm{IP} \ldots \ldots \ldots \ldots \ldots$ & 15 & 15 & 15 & 15 & 15 & 20 & 20 \\
\hline \multicolumn{8}{|l|}{ No. 4: } \\
\hline $6 \mathrm{ml} \mathrm{F}, 6 \mathrm{ml} \mathrm{IP} \ldots \ldots \ldots \ldots \ldots \ldots$ & 80 & 90 & 98 & 98 & 100 & 100 & 100 \\
\hline 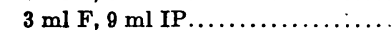 & 40 & 60 & 80 & 90 & 90 & 90 & 95 \\
\hline $11 / 2 \mathrm{ml} \mathrm{F}, 101 / 2 \mathrm{ml} \mathrm{IP} \ldots \ldots \ldots \ldots \ldots$ & 20 & 40 & 30 & 40 & 40 & 40 & 50 \\
\hline \multicolumn{8}{|l|}{ No. 2, refluxed without air: } \\
\hline $6 \mathrm{ml} \mathrm{F}, 6 \mathrm{ml} \mathrm{IP.............}$ & 60 & 70 & 90 & 90 & 90 & 90 & 90 \\
\hline $3 \mathrm{ml} \mathrm{F,} 9 \mathrm{ml} \mathrm{IP} \ldots \ldots \ldots \ldots \ldots \ldots \ldots$ & 30 & 50 & 65 & 70 & 75 & .75 & 80 \\
\hline $11 / 2 \mathrm{ml} \mathrm{F}, 101 / 2 \mathrm{ml} \mathrm{IP} \ldots \ldots \ldots \ldots \ldots$ & 5 & 10 & 10 & 10 & 10 & 15 & 15 \\
\hline \multicolumn{8}{|l|}{ No. 2 , refluxed with air: } \\
\hline $6 \mathrm{ml} \mathrm{F}, 6 \mathrm{ml} \mathrm{IP} \ldots \ldots \ldots \ldots$ & 60 & 75 & 95 & 95 & 95 & 95 & 100 \\
\hline 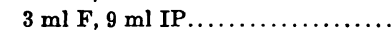 & 30 & 50 & 70 & 70 & 90 & 90 & 100 \\
\hline $11 / 2 \mathrm{ml} \mathrm{F}, 101 / 2 \mathrm{ml} \mathrm{IP} \ldots \ldots \ldots \ldots \ldots$ & 10 & 15 & 15 & 15 & 15 & 20 & 25 \\
\hline \multicolumn{8}{|l|}{ No. 3 , refluxed without air: } \\
\hline $6 \mathrm{ml} \mathrm{F}, 6 \mathrm{~m}^{\prime} \mathrm{IP} \ldots \ldots \ldots \ldots \ldots$ & 75 & 85 & 95 & 95 & 95 & 95 & 100 \\
\hline $3 \mathrm{ml} \mathrm{F}, 9 \mathrm{ml} \mathrm{IP} \ldots \ldots \ldots \ldots \ldots \ldots$ & 40 & 70 & 85 & 85 & 85 & 85 & 100 \\
\hline $11 / 2 \mathrm{ml} \mathrm{F}, 101 / 2 \mathrm{ml} \mathrm{IP} \ldots \ldots \ldots \ldots \ldots$ & 15 & 25 & 25 & 25 & 35 & 35 & 40 \\
\hline \multicolumn{8}{|l|}{ No. 3, refluxed with air: } \\
\hline $6 \mathrm{ml} \mathrm{F}, 6 \mathrm{ml} \mathrm{IP} \ldots \ldots \ldots \ldots \ldots \ldots$ & 75 & 90 & 95 & 95 & 95 & 95 & 100 \\
\hline $3 \mathrm{ml} \mathrm{F}, 9 \mathrm{ml} \mathrm{IP} \ldots \ldots \ldots \ldots \ldots \ldots$ & 40 & 60 & 80 & 80 & 85 & 85 & 95 \\
\hline $11 / 2 \mathrm{ml} \mathrm{F}, 101 / 2 \mathrm{ml} \mathrm{IP} \ldots \ldots \ldots \ldots \ldots$ & 10 & 20 & 20 & 20 & 30 & 30 & 50 \\
\hline
\end{tabular}

persist and bring about injury and death after the lighter compounds have vaporized and left. For complete killing of general weeds on roadsides, along railway roadbeds, and in similar situations, these heavy aromatics appear to be useful.

One additional set of experiments is reported in table 33 . The results, which agree with those of tables 30,31 , and 32 , indicate conclusively the relation mentioned above. The additional data of table 33 relate to the possible effects of storage upon the toxicity of oil fractions in the absence and presence of air. The gains in toxicity upon refluxing were small but perceptible. 


\section{STORAGE AND REFLUXING}

Toxicity Change of Gasolines on Standing. The sample reported on in table 2 (p. 86) was a fresh lot of commercial white gasoline. The straightrun and cracked samples reported in table 8 (p. 94) were produced by the same company, but had stood in cans in the headhouse from April, when they were received, until November, when the tests were run. Various other tests had indicated that gasoline increased in toxicity upon standing. Table 34 shows tests comparing a fresh straight-run sample with a white-gasoline sample that had stood in a flint-glass bottle for over a year in the headhouse. This test proves conclusively that the 1943 gasoline sample had gained in

TABLE 34

Toxicity of Old and Fresh Gasoline Samples on Carrots and Weeds; * NOVEMBER 16, 1944

\begin{tabular}{|c|c|c|c|c|c|c|c|c|}
\hline \multirow{3}{*}{ Sample and amount per culture } & \multicolumn{8}{|c|}{ Injury to carrots $(C)$ and weeds $(W)$ in per cent } \\
\hline & \multicolumn{2}{|c|}{2 days } & \multicolumn{2}{|c|}{4 days } & \multicolumn{2}{|c|}{6 days } & \multicolumn{2}{|c|}{8 days } \\
\hline & $\mathrm{C}$ & W & $\mathrm{C}$ & W & $\mathrm{C}$ & W & $\mathrm{C}$ & W \\
\hline 1943-sample gas, $10 \mathrm{ml} \ldots \ldots \ldots \ldots$ & 25 & 90 & 20 & 95 & 20 & 95 & 15 & 98 \\
\hline 1944-sample gas, $10 \mathrm{ml} \ldots \ldots \ldots \ldots$ & 0 & 98 & 0 & 100 & 0 & 100 & 0 & 100 \\
\hline
\end{tabular}

* Weeds referred to here were Brassica, Amsinckia, and Lactuca species.

toxicity, for it was the same sample reported in table 2 as noninjurious to carrots. Since the carrots reported in table 34 showed some recovery during the 8-day period, apparently the increase in toxicity was of the acute type. The 1944 sample was actually more toxic to the weeds.

Toxicity of Refluxed Samples. To test the possibility that oxidation is involved in the gain in toxicity of gasoline samples with time, some tests were run using gasoline fractions that had been refluxed with and without passage of air through the apparatus during the process. These fractions were compared with the unrefluxed ones. Table 6 (p. 92) reports the results. Refluxing seems to have affected toxicity slightly, if at all. Table 35 presents similar data on stove-oil fractions. In this work, again, oil refluxing had little effect on toxicity ; the presence of air increased toxicity against grass slightly, but not against onions. Refluxing always caused slight darkening of the samples; and, with air, darkening was more marked.

These results show that apparently the gain in toxicity of oils upon standing involves some reaction not accelerated by temperature alone. The presence of air during refluxing caused browning of the fractions, a burned odor, and slightly more toxicity than refluxing without air.

In comparison with refluxing, standing for several weeks, particularly in the light, brings about a yellow coloration of most fractions, and the development of a stale sour odor. This is true of white gasoline and kerosene fractions ; isoparaffinic fractions acquire a stale odor without change in color; stove oil undergoes no discernible change. 
Toxicity of Stored Fractions. In an attempt to study further the effects of standing, tests were run on stored samples of kerosene, gasoline, stove oil, mineral seal oil, and on certain narrow fractions.

In the first test, kerosene samples were placed in clear glass bottles and stored in the light and in a dark cupboard. Six months later (November 6, 1945) they were compared with a fresh sample and with the odorless kerosene received in January, 1944, and kept in a clear glass bottle in the laboratory. Also tested were the straight-run and cracked gasoline samples received in

\section{TABLE 35}

Toxicity of Stove-Oil Fractions to Onions and Grass; One Fraction ReFluXed with Air and ONe without Air; May 5, 1944

\begin{tabular}{|c|c|c|c|c|c|c|c|c|c|c|}
\hline \multirow{3}{*}{$\begin{array}{l}\text { Fraction and amounts of fraction }(F) \text { and } \\
\text { diluent (isoparaffin) applied per culture }\end{array}$} & \multicolumn{10}{|c|}{ Injury to onions $(O)$ and grass $(G)$, in per cent } \\
\hline & \multicolumn{2}{|c|}{1 day } & \multicolumn{2}{|c|}{3 days } & \multicolumn{2}{|c|}{5 days } & \multicolumn{2}{|c|}{10 days } & \multicolumn{2}{|c|}{15 days } \\
\hline & O & G & O & $\mathrm{G}$ & $\mathrm{O}$ & G & $\mathbf{O}$ & G & $\mathrm{O}$ & G \\
\hline \multicolumn{11}{|l|}{ No. 1: } \\
\hline $12 \mathrm{ml} \mathrm{F}, 0 \mathrm{ml} \mathrm{IP} \ldots \ldots \ldots$ & 70 & 80 & 60 & 90 & 50 & 90 & 25 & 100 & 15 & 100 \\
\hline $6 \mathrm{ml} \mathrm{F}, 6 \mathrm{ml} \mathrm{IP} \ldots \ldots \ldots \ldots \ldots \ldots$ & 10 & 40 & 10 & 50 & $\mathbf{5}$ & 50 & 0 & 50 & 0 & 50 \\
\hline \multicolumn{11}{|l|}{ No. 2: } \\
\hline $12 \mathrm{ml} \mathrm{F}, 0 \mathrm{ml} \mathrm{IP....}$ & 60 & 95 & 70 & 95 & 75 & 95 & 85 & 100 & 100 & 100 \\
\hline $6 \mathrm{ml} \mathrm{F}, 6 \mathrm{ml} \mathrm{IP} \ldots \ldots \ldots \ldots$ & 10 & 90 & 10 & 90 & 0 & 95 & $\mathbf{0}$ & 95 & $\mathbf{0}$ & 95 \\
\hline \multicolumn{11}{|l|}{ No. 3: } \\
\hline $12 \mathrm{ml} \mathrm{F}, 0 \mathrm{ml} \mathrm{IP...}$ & 50 & 90 & 40 & 95 & 40 & 95 & 40 & 100 & 30 & 100 \\
\hline $6 \mathrm{ml} \mathrm{F}, 6 \mathrm{ml} \mathrm{IP} \ldots \ldots \ldots \ldots$ & 10 & 80 & 10 & 80 & 0 & 90 & $\mathbf{0}$ & 90 & 0 & 95 \\
\hline \multicolumn{11}{|l|}{ No. 4: } \\
\hline $12 \mathrm{ml} \mathrm{F}, 0 \mathrm{ml} \mathrm{IP..}$ & 60 & 80 & 50 & 90 & 40 & 90 & 50 & 100 & 75 & 100 \\
\hline $6 \mathrm{ml} \mathrm{F}, 6 \mathrm{ml} \mathrm{IP} \ldots \ldots \ldots$ & 10 & 70 & 10 & 70 & 0 & 75 & 0 & 75 & 0 & 75 \\
\hline \multicolumn{11}{|l|}{ No. 1 , refluxed without air: } \\
\hline $12 \mathrm{ml} \mathrm{F}, 0 \mathrm{ml} \mathrm{IP} \ldots \ldots \ldots \ldots$ & 70 & 90 & 50 & 90 & 40 & 95 & 30 & 100 & 40 & 100 \\
\hline $6 \mathrm{ml} \mathrm{F}, 6 \mathrm{ml} \mathrm{IP} \ldots \ldots \ldots$ & 10 & 40 & 10 & 50 & 5 & 50 & 0 & 50 & 0 & 50 \\
\hline \multicolumn{11}{|l|}{ No. 1 , refluxed with air: } \\
\hline $12 \mathrm{ml} \mathrm{F,} 0 \mathrm{ml} \mathrm{IP} \ldots \ldots$ & 80 & 90 & 50 & 90 & 40 & 95 & 40 & 100 & 50 & 100 \\
\hline $6 \mathrm{ml} \mathrm{F}, 6 \mathrm{ml} \mathrm{IP} \ldots \ldots \ldots \ldots \ldots \ldots$ & 10 & 60 & 10 & 60 & $\mathbf{5}$ & 75 & 0 & 75 & 0 & 75 \\
\hline
\end{tabular}

April, 1944, the no. 3 sample of Shell white gasoline, and no. 1 sample of stove oil fractionated by the Chemistry Division in September, 1943, and a sample of the heavy isoparaffin received in April, 1944. Table 36 gives the results.

These tests show that within 6 months kerosene stored in the light will acquire a high toxicity, that the presence of air in the bottle is not essential to this increased toxicity, that gasoline samples became even more toxic than kerosene samples; that both gasoline and kerosene lost their selectivity on carrots, that the heavy isoparaffinic fraction behaved like kerosene, and that the stove oil was apparently unaffected.

A comparison of the odorless-kerosene fractions with the stove oil no. 1 brings out a significant fact concerning the toxicity gained by oil fractions stored for some time. The kerosene, originally almost free of toxicity and injurious only to grasses, gained toxicity to all three plants. The stove-oil fraction, which resembled the kerosene in boiling range, was, both originally and after storage, toxic to flax and barley but nontoxic to carrots. The toxicant that developed in odorless kerosene is therefore nonspecific, whereas that 
originally present and unchanged by storage in stove oil is highly specific. Both kerosene and gasoline samples stored in the light gained this same nonspecific toxicity - a fact indicating that a new type of compound resembling in specificity those responsible for chronic toxicity has appeared in the stored samples.

\section{TABLE 36}

Toxicity of Stored Gasoline and Kerosene to Flax, Barlex, and Carrots; NOVEMBeR 6, 1945

\begin{tabular}{|c|c|c|c|c|c|c|c|c|c|c|c|c|c|c|c|}
\hline \multirow{3}{*}{ Oil fraction and date obtained } & \multicolumn{15}{|c|}{ Injury to flax $(\mathrm{F})$, barley $(\mathrm{B})$, and carrots $(\mathrm{C})$, in per cent } \\
\hline & \multicolumn{3}{|c|}{1 day } & \multicolumn{3}{|c|}{2 days } & \multicolumn{3}{|c|}{3 days } & \multicolumn{3}{|c|}{5 days } & \multicolumn{3}{|c|}{9 days } \\
\hline & $\mathbf{F}$ & B & $\mathrm{C}$ & $\mathrm{F}$ & B & $\mathrm{C}$ & $\mathrm{F}$ & B & $\mathrm{C}$ & $\mathrm{F}$ & B & $\mathrm{C}$ & $\mathbf{F}$ & B & $\mathrm{C}$ \\
\hline Kerosene, Nov. 5, 1945. & 0 & $0^{*}$ & 0 & 0 & 50 & 0 & 0 & 75 & 0 & 0 & 75 & 0 & $0 \S$ & 90 & 0 \\
\hline Kerosene, May $16,1945, \mathrm{D} 1 \dagger \ldots$ & 0 & 0 & 0 & 0 & 50 & 0 & 0 & 65 & 0 & 0 & 75 & 0 & $0 \S$ & 90 & 0 \\
\hline Kerosene, May $16,1945, \mathrm{D} 1 / 2 \dagger$. & 0 & 0 & 0 & 0 & 50 & 0 & 0 & 65 & 0 & 0 & 75 & 0 & $0 \S$ & 90 & 0 \\
\hline Kerosene, May 16, 1945, L $1 \ddagger \ldots$ & 100 & 100 & 70 & 100 & 100 & 70 & 100 & 100 & 70 & 100 & 100 & 60 & 100 & 100 & 50 \\
\hline Kerosene, May 16,1945, L $1 / 2 \nmid \ldots \ldots$ & 75 & 25 & 20 & 75 & 60 & 20 & 75 & 80 & 20 & 60 & 90 & 10 & 60 & 90 & $\mathbf{5}$ \\
\hline Odorless kerosene, Jan. 1, 1944, D $1 \dagger$. & 5 & 0 & 10 & 10 & 20 & 10 & 10 & 40 & 15 & 10 & 60 & 10 & 10 & 90 & $\mathbf{5}$ \\
\hline Odorless kerosene, Jan. 1, 1944, Lł... & 90 & 50 & 20 & 95 & 75 & 25 & 95 & 85 & 25 & 95 & 90 & 15 & 100 & 95 & 5 \\
\hline Range fuel, Nov. $5,1945 \ldots \ldots \ldots \ldots$ & 100 & 100 & 20 & 100 & 100 & 15 & 100 & 100 & 15 & 100 & 100 & 20 & 100 & 100 & 15 \\
\hline E-1 & 100 & 90 & 35 & 100 & 100 & 25 & 100 & 100 & 25 & 100 & 100 & 15 & 100 & 100 & 10 \\
\hline & 100 & 100 & 50 & 100 & 100 & 50 & 100 & 100 & 50 & 100 & 100 & 40 & 100 & 100 & 30 \\
\hline Gas-regular motor fuel, Feb., 1945, L. . & 100 & 95 & 65 & 100 & 95 & 65 & 100 & 95 & 65 & 100 & 90 & 50 & 100 & 90 & 35 \\
\hline Shell white gas, Sept., 1943, L........ & 100 & 100 & 90 & 100 & 100 & 90 & 100 & 100 & 90 & 100 & 100 & 85 & 100 & 100 & 75 \\
\hline Stove oil no. 1 , Sept. 1,1943, L......... & 100 & 90 & 0 & 100 & 100 & 0 & 100 & 100 & 0 & 100 & 100 & 0 & 100 & 100 & 0 \\
\hline \multirow[t]{3}{*}{ Isoparaffin, heavy, April 1, 1944, L...... } & 100 & 25 & 15 & 100 & 75 & 20 & 100 & 95 & 35 & 100 & 100 & 30 & 100 & 100 & 25 \\
\hline & \multicolumn{3}{|c|}{12 days } & \multicolumn{3}{|c|}{16 days } & \multicolumn{3}{|c|}{23 days } & \multicolumn{3}{|c|}{30 days } & \multicolumn{3}{|c|}{34 days } \\
\hline & $\mathrm{F}$ & B & C & $\mathrm{F}$ & B & $\mathrm{C}$ & F & B & C & F & B & C & F & B & C \\
\hline Kero: & 0 & 95 & 0 & 0 & 100 & 0 & 0 & 100 & 0 & 0 & 100 & 0 & 0 & 100 & 0 \\
\hline Keros & 0 & 95 & 0 & 0 & 100 & 0 & 0 & 100 & 0 & 0 & 100 & 0 & 0 & 100 & 0 \\
\hline Keros & 0 & 95 & 0 & 0 & 100 & 0 & 0 & 100 & 0 & 0 & 100 & 0 & 0 & 100 & 0 \\
\hline Kero & 100 & 100 & 40 & 100 & 100 & 30 & 100 & 100 & 15 & 100 & 100 & 10 & 100 & 100 & 10 \\
\hline Kerose & 50 & 100 & 5 & 40 & 100 & 5 & 25 & 100 & 0 & 25 & 100 & 0 & 25 & 100 & 0 \\
\hline Odorless kerosene. Jan. 1, 1944, D $1 \nmid \ldots$ & 25 & 95 & 5 & 15 & 100 & 5 & 10 & 100 & 0 & 10 & 100 & 0 & $\mathbf{5}$ & 100 & 0 \\
\hline Odorless kerosene, Jan. 1,1944 . Lł..... & 100 & 100 & $\mathbf{5}$ & 100 & 100 & 5 & 100 & 100 & 0 & 100 & 100 & 0 & 100 & 100 & 0 \\
\hline Range fuel, Nov. $5,1945 \ldots \ldots \ldots \ldots$ & 100 & 100 & 15 & 100 & 100 & 10 & 100 & 100 & 10 & 100 & 100 & $\mathbf{5}$ & 100 & 100 & 5 \\
\hline E-1381, April 1, 1945, L... & 100 & 100 & 10 & 100 & 100 & 10 & 100 & 100 & 5 & 100 & 100 & $\mathbf{5}$ & 100 & 100 & 5 \\
\hline E-1380, April 1, 1945, L. ............ & 100 & 100 & 30 & 100 & 100 & 25 & 100 & 100 & 20 & 100 & 100 & 15 & 100 & 100 & 10 \\
\hline Gas-regular motor fuel, Feb., 1945, L. & 100 & 90 & 30 & 100 & 90 & 25 & 100 & 90 & 20 & 100 & 90 & 15 & 100 & 90 & 10 \\
\hline Shell white gas, Sept., 1943, L....... & 100 & 100 & 65 & 100 & 100 & 60 & 100 & 90 & 40 & 100 & 100 & 30 & 100 & 100 & 30 \\
\hline Stove oil no. 1 , Sept. $1,1943, \mathrm{~L} .$. & 100 & 100 & 0 & 100 & 100 & 0 & 100 & 100 & 0 & 100 & 100 & 0 & 100 & 100 & 0 \\
\hline Isoparaffin, heavy, April 1, 1944, L. & 100 & 100 & 25 & 100 & 100 & 20 & 100 & 100 & 10 & 100 & 100 & 5 & 100 & 100 & 0 \\
\hline
\end{tabular}

* Barley plants sprayed with fresh kerosene showed positive geotropism 24 hours after spraying. Stored kerosene did not have this effect.

D signifies storage in the dark: 1 , in a full bottle; $1 / 2$, in a bottle only half full.

$\$$ L signifies storage in the light.

Because of the marked increase in toxicity of the gasoline samples to carrots, tests were run on the lighter three gasoline fractions previously used, on all four stove-oil fractions, and on the mineral seal oil stored both in the dark and in the light. The data appear in table 37. Considering the results on carrots, to which the gasoline was not originally toxic, one sees that storage in 
the light had considerably increased the nonspecific acute toxicity of these samples. Stove-oil fractions had not changed. Mineral seal oil, though not toxic to carrots, had increased in toxicity to flax and barley.

\section{TABLE 37}

Toxicity of Gasoline and Stove-OIl Fractions, Stove-Oil Samples, and Mineral Seal Orl to Flax, Barley, and Carrots; November 9, 1945

\begin{tabular}{|c|c|c|c|c|c|c|c|c|c|c|c|c|c|c|c|}
\hline \multirow{3}{*}{$\begin{array}{l}\text { Fraction no. } \\
\text { and } \\
\text { storage condition }\end{array}$} & \multicolumn{15}{|c|}{ Injury to flax $(F)$, barley $(B)$, and carrots $(C)$, in per cent } \\
\hline & \multicolumn{3}{|c|}{1 day } & \multicolumn{3}{|c|}{2 days } & \multicolumn{3}{|c|}{3 days } & \multicolumn{3}{|c|}{4 days } & \multicolumn{3}{|c|}{6 days } \\
\hline & $\mathbf{F}$ & B & C & $\mathbf{F}$ & B & C & $\mathrm{F}$ & B & C & $\mathbf{F}$ & B & $\mathrm{C}$ & $\mathbf{F}$ & $\mathbf{B}$ & $\mathbf{C}$ \\
\hline Shell white gasoline: & & & & & & & & & & & & & & & \\
\hline $1 \mathrm{~L}^{*} \ldots \ldots \ldots \ldots \ldots$ & 100 & 90 & 60 & 100 & 90 & 60 & 100 & 90 & 60 & 100 & 85 & 60 & 100 & 80 & 50 \\
\hline $2 \mathrm{~L} \ldots$ & 100 & 90 & 90 & 100 & 100 & 90 & 100 & 100 & 90 & 100 & 100 & 85 & 100 & 100 & 80 \\
\hline $3 \mathrm{~L} \ldots$. & 100 & 100 & 85 & 100 & 100 & 85 & 100 & 100 & 85 & 100 & 100 & 85 & 100 & 100 & 80 \\
\hline \multicolumn{16}{|l|}{ Stove oil: } \\
\hline $1 \mathrm{~L} \ldots \ldots$ & 95 & 90 & 0 & 100 & 100 & 5 & 100 & 100 & 5 & 100 & 100 & 5 & 100 & 100 & 5 \\
\hline $2 \mathrm{~L} .$. & 100 & 90 & 0 & 100 & 100 & 0 & 100 & 100 & 0 & 100 & 100 & 0 & 100 & 100 & $\mathbf{0}$ \\
\hline $3 \mathrm{~L} .$. & 100 & 80 & 0 & 100 & 100 & 0 & 100 & 100 & 0 & 100 & 100 & 0 & 100 & 100 & 0 \\
\hline $4 \mathrm{~L} \ldots \ldots \ldots \ldots$ & 100 & 80 & 5 & 100 & 100 & 5 & 100 & 100 & 5 & 100 & 100 & 5 & 100 & 100 & 5 \\
\hline \multicolumn{16}{|l|}{ Sea Side stove oil: } \\
\hline $1 \mathrm{~L} t \ldots \ldots \ldots \ldots$ & 100 & 90 & 5 & 100 & 100 & 0 & 100 & 100 & 0 & 100 & 100 & 0 & 100 & 100 & 0 \\
\hline $2 \mathrm{~L} \dagger \ldots \ldots \ldots \ldots$ & 100 & 95 & 90 & 100 & 100 & 95 & 100 & 100 & 95 & 100 & 100 & 95 & 100 & 100 & 95 \\
\hline \multicolumn{16}{|l|}{ Mineral seal oil: } \\
\hline 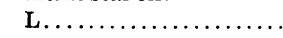 & 0 & 0 & 0 & 0 & 0 & 0 & 0 & 0 & 0 & 0 & $0 \ddagger$ & 0 & $\mathbf{5}$ & $0 \pm$ & 0 \\
\hline \multirow[t]{3}{*}{ 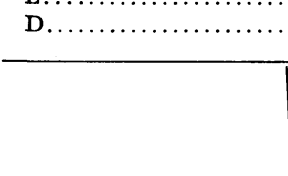 } & 0 & 0 & 0 & 0 & 0 & 0 & 0 & 0 & 0 & 0 & $0 \ddagger$ & 0 & 0 & $0 \ddagger$ & 0 \\
\hline & \multicolumn{3}{|c|}{9 days } & \multicolumn{3}{|c|}{16 days } & \multicolumn{3}{|c|}{24 days } & \multicolumn{3}{|c|}{31 days } & \multicolumn{3}{|c|}{38 days } \\
\hline & $\mathbf{F}$ & B & C & $\mathbf{F}$ & $\mathbf{B}$ & C & $\mathbf{F}$ & B & C & $\mathrm{F}$ & B & C & $\mathrm{F}$ & B & C \\
\hline \multicolumn{16}{|l|}{ Shell white gasolin } \\
\hline $1 \mathrm{~L}^{*} \ldots \ldots \ldots \ldots$ & 100 & 75 & 40 & 100 & 50 & 25 & 100 & 20 & 20 & 100 & 15 & 20 & 100 & 0 & 15 \\
\hline $2 \mathrm{~L} \ldots$ & 100 & 100 & 65 & 100 & 100 & 40 & 100 & 100 & 25 & 100 & 100 & 25 & 100 & 100 & 20 \\
\hline $3 \mathrm{~L} \ldots \ldots$ & 100 & 100 & 70 & 100 & 100 & 50 & 100 & 100 & 35 & 100 & 100 & 25 & 100 & 100 & 20 \\
\hline \multicolumn{16}{|l|}{ Stove oil: } \\
\hline $1 \mathrm{~L} \ldots \ldots$ & 100 & 100 & 5 & 100 & 100 & 0 & 100 & 100 & 0 & 100 & 100 & 0 & 100 & 100 & 0 \\
\hline $2 \mathrm{~L} \ldots$. & 100 & 100 & 0 & 100 & 100 & 0 & 100 & 100 & 0 & 100 & 100 & 0 & 100 & 100 & 0 \\
\hline $3 \mathrm{~L} . .$. & 100 & 100 & 0 & 100 & 100 & 0 & 100 & 100 & 0 & 100 & 100 & 0 & 100 & 100 & 0 \\
\hline $4 \mathrm{~L} \ldots \ldots \ldots \ldots$ & 100 & 100 & $\mathbf{5}$ & 100 & 100 & 0 & 100 & 100 & 0 & 100 & 100 & 0 & 100 & 100 & 0 \\
\hline \multicolumn{16}{|l|}{ Sea Side stove oil: } \\
\hline $1 \mathrm{~L}+\ldots \ldots \ldots \ldots$ & 100 & 100 & 0 & 100 & 100 & 0 & 100 & 100 & 0 & 100 & 100 & 0 & 100 & 100 & 0 \\
\hline $2 \mathrm{~L} \dagger \ldots \ldots \ldots$ & 100 & 100 & 90 & 100 & 100 & 80 & 100 & 100 & 80 & 100 & 100 & 65 & 100 & 100 & 50 \\
\hline \multicolumn{16}{|l|}{ Mineral seal oil: } \\
\hline L............. & 15 & $5 \ddagger$ & 0 & 25 & 25 & 0 & 50 & 50 & 0 & 50 & 75 & 0 & 40 & 80 & $\mathbf{0}$ \\
\hline D.... & 3 & $0 \ddagger$ & 0 & 10 & 15 & 0 & 50 & 40 & 0 & 60 & 70 & 0 & 50 & 60 & $\mathbf{0}$ \\
\hline
\end{tabular}

* The designation $\mathrm{L}$ indicates that the sample had been stored in the light; $\mathrm{D}$ indicates storage in the dark. $\dagger$ Sea Side stove oil no. 1 had a gravity rating ( ${ }^{\circ}$ A.P.I.) of 38.7 ; no. 2 of 34.7 .

$\ddagger$ Four days after spraying, the barley plants showed strong positive geotropism. This lasted for somewhat over a week.

A possible explanation for these observations is that the changes occurring in low-boiling refined petroleum fractions in the light involve formation of peroxides of the aliphatic compounds. Peroxide production may be autocatalytic; the time of storage may simply represent the induction period necessary to bring about rapid oxidation in the air; light greatly accelerates 
this process. When such a stored oil is applied to the plant, rapid formation of peroxide causes enhanced acute, nonselective toxicity. Heavier fractions less subject to peroxide formation may undergo similar changes on a reduced scale and at a much slower rate. The aromatic compounds present in unrefined fractions act as antioxidants; but, being toxic, their original toxicity would mask peroxide effects. From these postulations it follows that the lighter the fraction the greater is peroxide formation; the more highly refined, the greater the relative increase in toxicity; the higher the toxicity due to peroxides, the lower the selectivity.

\section{PURE COMPOUNDS}

There are two approaches to the experimental determination of the toxic nature of oils. One is to use oil fractions of different types and to explain (if possible) their behavior on the basis of existing information regarding their composition. Such an approach has been used in the work described in the preceding sections.

Toxicity of Aromatic Compounds. A second approach is to use pure ${ }^{10} \mathrm{com}-$ pounds of known structure and to compare the results with those obtained with the oil fractions. Since the work on oil fractions had indicated that aromatic compounds play an important role, the first test compared the toxicity of benzene, toluene, and xylene on grass. Cultures were sprayed with the pure hydrocarbons and with mixtures containing 50 per cent, 25 per cent, and 12.5 per cent of the hydrocarbons in odorless kerosene. Table 38 presents the results.

The toxicity of these three compounds evidently increases with increasing substitutions in the benzene ring, the xylene being the most toxic. Their boiling points are as follows : benzene, $176.7^{\circ} \mathrm{F}$; toluene, $231.8^{\circ} \mathrm{F}$; and xylene, $280.4^{\circ}$ to $287.6^{\circ} \mathrm{F}$. Xylene was much lower in toxicity than the compounds responsible for herbicidal action in oil fractions: it was required in full strength to injure the grass seriously, and at concentrations below 50 per cent it was nontoxic.

For a clearer picture of the comparative toxicity of xylene, the experiment reported in table 39 was performed. Here xylene, TS-28 solvent, gasoline, and stove oil were used in varying volumes on grass. Judging from the results, xylene is approximately equal to gasoline in toxicity but is less toxic than TS28 and stove oil. These latter both contain aromatics having higher boiling points than xylene. Gasoline and stove oil have only about 20 to 30 per cent unsaturates, however, whereas xylene and TS-28 solvent are both practically pure aromatics.

To study the relation of xylene-type aromatics to selectivity of oils, xylene was applied to grass and carrot cultures in a range of concentrations, the heavy isoparaffinic fraction being used as a diluent. Cracked gasoline was used in comparison as a check on the toxicity of an oil fraction. The results are reported in table 40.

\footnotetext{
${ }^{11}$ The hydrocarbons used in these studies were not tested for purity. They were obtained from commercial supply houses or from interested industrial firms and were presumed to be reasonably pure.
} 
TABLE 38

Toxicity of Benzene, Toluene, and X Ylene to Grass ; APRIL 4, 1944

\begin{tabular}{|c|c|c|c|}
\hline \multirow{2}{*}{$\begin{array}{l}\text { Hydrocarbon and amount of } \\
\text { hydrocarbon }(H) \text { and diluent (odorless } \\
\text { kerosene) applied per culture }\end{array}$} & \multicolumn{3}{|c|}{ Injury to grass, in per cent } \\
\hline & 1 day & 2 days & 3 days \\
\hline \multicolumn{4}{|l|}{ Benzene; } \\
\hline $6 \mathrm{ml} \mathrm{H}, 0 \mathrm{ml} \mathrm{OK} \ldots \ldots \ldots \ldots \ldots \ldots \ldots$ & 50 & 60 & 60 \\
\hline $3 \mathrm{ml} \mathrm{H.} 3 \mathrm{ml} \mathrm{OK} \ldots \ldots \ldots \ldots \ldots \ldots$ & $\mathbf{5}$ & 10 & 10 \\
\hline $11 / 2 \mathrm{ml} \mathrm{H}, 41 / 2 \mathrm{ml} \mathrm{OK} \ldots \ldots \ldots \ldots \ldots$ & $\mathbf{0}$ & 5 & 5 \\
\hline $3 / 4 \mathrm{ml} \mathrm{H}, 51 / 4 \mathrm{ml} \mathrm{OK} \ldots \ldots \ldots \ldots \ldots \ldots \ldots$ & $\mathbf{0}$ & 0 & 0 \\
\hline \multicolumn{4}{|l|}{ Toluene: } \\
\hline $6 \mathrm{ml} \mathrm{H}, 0 \mathrm{ml} \mathrm{OK} \ldots \ldots \ldots \ldots \ldots \ldots \ldots \ldots$ & 75 & 80 & 80 \\
\hline $3 \mathrm{ml} \mathrm{H}, 3 \mathrm{ml} \mathrm{OK} \ldots \ldots \ldots \ldots \ldots \ldots \ldots$ & 25 & 25 & 25 \\
\hline $11 / 2 \mathrm{ml} \mathrm{H}, 41 / 2 \mathrm{ml} \mathrm{OK} \ldots \ldots \ldots \ldots \ldots \ldots$ & $\mathbf{0}$ & 5 & $\mathbf{5}$ \\
\hline $8 / 4 \mathrm{ml} \mathrm{H}, 51 / 4 \mathrm{ml} \mathrm{OK} \ldots \ldots \ldots \ldots \ldots \ldots$ & $\mathbf{0}$ & 0 & 0 \\
\hline \multicolumn{4}{|l|}{ Xylene: } \\
\hline $6 \mathrm{ml} \mathrm{H}, 0 \mathrm{ml} \mathrm{OK} \ldots \ldots \ldots \ldots \ldots \ldots$ & 95 & 95 & 95 \\
\hline $3 \mathrm{ml} \mathrm{H}, 3 \mathrm{ml} \mathrm{OK} \ldots \ldots \ldots \ldots \ldots \ldots$ & 50 & 50 & 50 \\
\hline $11 / 2 \mathrm{ml} \mathrm{H}, 41 / 2 \mathrm{ml} \mathrm{OK} . \ldots \ldots \ldots \ldots \ldots \ldots$ & 0 & 0 & 0 \\
\hline $8 / 4 \mathrm{ml} \mathrm{H}, 51 / 4 \mathrm{ml} \mathrm{OK} \ldots \ldots \ldots \ldots \ldots \ldots \ldots$ & 0 & 0 & 0 \\
\hline
\end{tabular}

TABLE 39

Toxicity of Xylene, TS-28 Solvent, White Gasoline, and Stove OIL to FoxtaIl Grass ; APRIL 12, 1944

\begin{tabular}{|c|c|c|c|c|c|c|}
\hline \multirow{2}{*}{$\begin{array}{l}\text { Oil and amount } \\
\text { applied per culture }\end{array}$} & \multicolumn{6}{|c|}{ Injury to grass, in per cent } \\
\hline & 1 day & 2 days & 3 days & 7 days & 12 days & 17 days \\
\hline \multicolumn{7}{|l|}{ Xylene: } \\
\hline $10 \ldots \ldots \ldots \ldots \ldots \ldots$ & 0 & 20 & 20 & 25 & 30 & 50 \\
\hline $15 \ldots \ldots \ldots \ldots \ldots \ldots$ & 60 & 70 & 80 & 80 & 80 & 80 \\
\hline $22 \ldots \ldots \ldots \ldots \ldots \ldots$ & 80 & 90 & $\theta 0$ & 90 & 90 & 90 \\
\hline $32 \ldots \ldots \ldots \ldots \ldots \ldots$ & 95 & 95 & 95 & 95 & 95 & 95 \\
\hline TS-28 solvent: & & & & & & \\
\hline $10 \ldots \ldots \ldots \ldots \ldots$ & 25 & 30 & 35 & 50 & 65 & 70 \\
\hline $15 \ldots \ldots \ldots \ldots \ldots$ & 80 & 80 & 90 & 95 & 100 & 100 \\
\hline $22 \ldots \ldots \ldots \ldots$ & 90 & 90 & 95 & 95 & 95 & 100 \\
\hline $32 \ldots \ldots \ldots \ldots \ldots$ & 95 & 95 & 100 & 100 & 100 & 100 \\
\hline \multicolumn{7}{|l|}{ White gasoline: } \\
\hline $10 \ldots \ldots \ldots \ldots \ldots \ldots$ & 15 & 15 & 20 & 20 & 25 & 40 \\
\hline $15 \ldots \ldots \ldots \ldots \ldots \ldots$ & 75 & 75 & 80 & 80 & 80 & 90 \\
\hline $22 \ldots \ldots \ldots \ldots \ldots \ldots$ & 80 & 80 & 80 & 85 & 85 & 85 \\
\hline $32 \ldots \ldots \ldots \ldots \ldots$ & 90 & 90 & 90 & 90 & 90 & 90 \\
\hline \multicolumn{7}{|l|}{ Stove oil: } \\
\hline $10 \ldots \ldots \ldots \ldots$ & 40 & 40 & 40 & 65 & 75 & 75 \\
\hline $15 \ldots \ldots \ldots \ldots \ldots$ & 60 & 60 & 65 & 90 & 95 & 95 \\
\hline $22 \ldots \ldots \ldots \ldots \ldots \ldots$ & 80 & 80 & 85 & 98 & 100 & 100 \\
\hline $32 \ldots \ldots \ldots \ldots \ldots \ldots$ & 95 & 95 & 95 & 100 & 100 & 100 \\
\hline
\end{tabular}

The data show that with these oils, as with other herbicides, selectivity is only relative (Crafts, 1946). Xylene, if concentrated enough, will kill carrots as well as grass. Mixed 50:50 with the relatively nontoxic isoparaffinic fraction, it was highly selective, damaging young grass 90 per cent but causing carrots only a slight injury, from which they soon recovered. 
TABLE 40

Toxicity of Xylene and Gasoline to Grass and Ciarots; ; June 20, 1944

\begin{tabular}{|c|c|c|c|c|c|c|c|c|c|c|c|c|}
\hline \multirow{3}{*}{$\begin{array}{l}\text { Oil and amounts of oil (O) } \\
\text { and diluent (isoparaffin) } \\
\text { applied per culture }\end{array}$} & \multicolumn{12}{|c|}{ Injury to grass $(G)$ and carrots $(C)$, in per cent } \\
\hline & \multicolumn{2}{|c|}{1 day } & \multicolumn{2}{|c|}{2 days } & \multicolumn{2}{|c|}{3 days } & \multicolumn{2}{|c|}{4 days } & \multicolumn{2}{|c|}{5 days } & \multicolumn{2}{|c|}{8 days } \\
\hline & G & $\mathbf{C}$ & G & $\mathrm{C}$ & G & $\mathbf{C}$ & $\mathbf{G}$ & C & G & $\mathbf{C}$ & G & $\mathbf{C}$ \\
\hline \multicolumn{13}{|l|}{ Xylene: } \\
\hline $0 \mathrm{ml} \mathrm{O}, 8 \mathrm{ml} \mathrm{IP..}$ & 0 & $\mathbf{0}$ & 0 & 0 & 0 & $\mathbf{0}$ & 0 & 0 & 0 & 0 & 0 & 0 \\
\hline $1 \mathrm{ml} \mathrm{O}, 7 \mathrm{ml} \mathrm{IP..}$ & 0 & 0 & 0 & $\mathbf{0}$ & 0 & 0 & 0 & $\mathbf{0}$ & $\mathbf{0}$ & 0 & $0^{*}$ & 0 \\
\hline $2 \mathrm{ml} \mathrm{O}, 6 \mathrm{ml} \mathrm{IP} \ldots \ldots \ldots \ldots \ldots$ & 10 & 0 & 10 & 0 & 10 & $\mathbf{0}$ & 10 & 0 & $\mathbf{0}$ & 0 & $0^{*}$ & 0 \\
\hline $3 \mathrm{ml} \mathrm{O}, 5 \mathrm{ml} \mathrm{IP} . \ldots \ldots \ldots \ldots$ & 25 & 0 & 35 & 0 & 35 & 0 & 35 & 0 & 35 & 0 & 40 & 0 \\
\hline $4 \mathrm{ml} \mathrm{O}, 4 \mathrm{ml} \mathrm{IP} \ldots \ldots \ldots$ & 90 & 10 & 90 & 10 & 90 & 10 & 90 & 10 & 90 & 5 & 90 & 5 \\
\hline 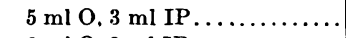 & 100 & 50 & 90 & 75 & 90 & 60 & 90 & 60 & 90 & 50 & 90 & 75 \\
\hline $6 \mathrm{ml} \mathrm{O.} 2 \mathrm{ml} \mathrm{IP \ldots \ldots \ldots \ldots \ldots ......}$ & 100 & 100 & 100 & 100 & 100 & 100 & 100 & 100 & 100 & 100 & 100 & 100 \\
\hline 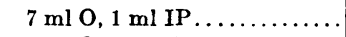 & 100 & 100 & 100 & 100 & 100 & 100 & 90 & 100 & 90 & 100 & 90 & 100 \\
\hline $8 \mathrm{ml} \mathrm{O}, 0 \mathrm{ml} \mathrm{IP......}$ & 100 & 100 & 100 & 100 & 90 & 100 & 80 & 100 & 80 & 100 & 80 & 100 \\
\hline \multicolumn{13}{|l|}{ Cracked gasoline: } \\
\hline $8 \mathrm{ml} \mathrm{O}, 0 \mathrm{ml} \mathrm{IP...}$ & 90 & 10 & 100 & 20 & 100 & 25 & 100 & 25 & 95 & 15 & 95 & 10 \\
\hline $6 \mathrm{ml} \mathrm{O}, 2 \mathrm{ml} \mathrm{IP.......}$ & 50 & 0 & 75 & 0 & 75 & $\mathbf{0}$ & 75 & 0 & 75 & 0 & 80 & 0 \\
\hline $4 \mathrm{ml} \mathrm{O}, 4 \mathrm{ml} \mathrm{IP..........}$ & 20 & 0 & 50 & 0 & 50 & 0 & 60 & 0 & 60 & 0 & 75 & 0 \\
\hline
\end{tabular}

* Chronic injury starting.

TABLE 41

Toxicity of Benzene, Ethylbenzene, and Diethylbenzene to Flax, Barlet, AND CARROTS; JANUARY 15, 1946

\begin{tabular}{|c|c|c|c|c|c|c|c|c|c|}
\hline \multirow{3}{*}{$\begin{array}{l}\text { Oil and amounts of oil }(\mathrm{O}) \\
\text { and diluent } \\
\text { (isoparaffin) applied per culture }\end{array}$} & \multicolumn{9}{|c|}{ Injury to flax (F), barley (B), and carrots (C), in per cent } \\
\hline & \multicolumn{3}{|c|}{1 day } & \multicolumn{3}{|c|}{2 days } & \multicolumn{3}{|c|}{3 days } \\
\hline & $\mathrm{F}$ & $\mathbf{B}$ & $\mathrm{C}$ & $\mathbf{F}$ & $\mathbf{B}$ & C & $\mathbf{F}$ & B & $\mathrm{C}$ \\
\hline \multicolumn{10}{|l|}{ Benzene: } \\
\hline $8 \mathrm{ml} \mathrm{O}, 0 \mathrm{ml} \mathrm{IP.}$ & 75 & 50 & 40 & 90 & 50 & 35 & 90 & 50 & 30 \\
\hline $6 \mathrm{ml} \mathrm{O}, 2 \mathrm{ml} \mathrm{IP...}$ & 50 & $\mathbf{5}$ & $\mathbf{5}$ & 60 & 25 & 5 & 60 & 25 & 10 \\
\hline $4 \mathrm{ml} \mathrm{O,4} \mathrm{ml} \mathrm{IP........}$ & 50 & 5 & 0 & 60 & 5 & 5 & 40 & 5 & $\mathbf{5}$ \\
\hline $2 \mathrm{ml} \mathrm{O}, 6 \mathrm{ml} \mathrm{IP} \ldots \ldots \ldots$ & 25 & 0 & 0 & 40 & 5 & 0 & 20 & 0 & 0 \\
\hline \multicolumn{10}{|l|}{ Ethylbenzene: } \\
\hline $8 \mathrm{ml} \mathrm{O}, 0 \mathrm{ml} \mathrm{IP} \ldots$ & 95 & 90 & 90 & 100 & 100 & 95 & 100 & 100 & 100 \\
\hline $6 \mathrm{ml} \mathrm{O}, 2 \mathrm{ml} \mathrm{IP} \ldots \ldots$ & 90 & 90 & 80 & 100 & 100 & 90 & 100 & 100 & 90 \\
\hline $4 \mathrm{ml} \mathrm{O}, 4 \mathrm{ml} \mathrm{IP....}$ & 50 & 50 & 40 & 90 & 90 & 75 & 90 & 90 & 75 \\
\hline $2 \mathrm{ml} \mathrm{O}, 6 \mathrm{ml} \mathrm{IP....}$ & 10 & 10 & 0 & 60 & 75 & 5 & 70 & 75 & 10 \\
\hline \multicolumn{10}{|l|}{ Diethylbenzene: } \\
\hline $8 \mathrm{ml} \mathrm{O}, 0 \mathrm{ml} \mathrm{IP..}$ & 95 & 90 & 95 & 100 & 100 & 100 & 100 & 100 & 100 \\
\hline $6 \mathrm{ml} \mathrm{O}, 2 \mathrm{ml} \mathrm{IP} \ldots$ & 90 & 90 & 80 & 100 & 100 & 100 & 100 & 100 & 100 \\
\hline $4 \mathrm{ml} \mathrm{O}, 4 \mathrm{ml} \mathrm{IP} \ldots \ldots \ldots \ldots$ & 50 & 50 & 10 & 100 & 100 & 30 & 100 & 100 & 40 \\
\hline $2 \mathrm{ml} \mathrm{O}, 6 \mathrm{ml} \mathrm{IP} \ldots \ldots \ldots \ldots$ & 10 & 10 & 0 & 90 & 90 & 5 & 95 & 90 & $\mathbf{5}$ \\
\hline
\end{tabular}

Cracked gasoline when used straight caused some injury to carrots. This contrasts with the tests reported in table 4 , in which a sample of commercial white gasoline, probably a blend of cracked and straight-run gasolines, proved nontoxic to carrots. At 75 per cent in isoparaffin, cracked gasoline was not injurious to them and did not completely kill the grass plants. 
These experiments indicate how critical is the problem of providing a selective oil spray suitable for commercial application under varying field conditions. The fact that stove oil, a low-priced commercial fuel fraction, has proved so effective is purely fortuitous. By coincidence this fraction proved to combine the particular properties required for killing weeds in carrots. As al-

TABLE 42

Toxicity of Pure Aromatic Hydrocarbons* to Barlex, Carrots, and Onions; MaY 5, 1944

\begin{tabular}{|c|c|c|c|c|c|c|c|c|c|c|c|c|}
\hline \multirow{3}{*}{$\begin{array}{l}\text { Compound (mixture of } \\
20 \text { per cent concentration in } \\
\text { isoparaffin) }\end{array}$} & \multicolumn{12}{|c|}{ Injury to barley $(B)$, carrots $(C)$, and onions $(O)$, in per cent } \\
\hline & \multicolumn{3}{|c|}{1 day } & \multicolumn{3}{|c|}{3 days } & \multicolumn{3}{|c|}{5 days } & \multicolumn{3}{|c|}{7 days } \\
\hline & B & $\mathrm{C}$ & $\mathrm{O}$ & B & C & $\mathrm{O}$ & B & C & $\mathbf{O}$ & $\mathbf{B}$ & C & $\mathbf{O}$ \\
\hline Isopropylbenzene.......... & 0 & 0 & 0 & 0 & 0 & 0 & 0 & 0 & 0 & 5 & 0 & 0 \\
\hline Diisopropylbenzene ........ & 0 & 0 & 0 & 0 & 0 & 0 & 0 & 0 & 0 & 10 & 5 & 0 \\
\hline Triisopropylbenzene ... & 0 & 0 & 0 & 0 & 0 & 0 & $\mathbf{5}$ & 0 & 0 & 15 & 5 & 0 \\
\hline Tetraisopropylbenzene.. & 0 & 0 & 0 & 0 & 0 & 0 & 5 & 0 & 0 & 20 & 10 & 0 \\
\hline Cymene....................... & 5 & 0 & 0 & 5 & 0 & $\mathbf{0}$ & $\mathbf{5}$ & 0 & 0 & $\mathbf{5}$ & 0 & 0 \\
\hline \multirow[t]{3}{*}{ Methylcyclopentane .......... } & 0 & 0 & 0 & 0 & 0 & 0 & 0 & 0 & 0 & 5 & $\mathbf{0}$ & 0 \\
\hline & \multicolumn{3}{|c|}{10 days } & \multicolumn{3}{|c|}{13 days } & \multicolumn{3}{|c|}{15 days } & \multicolumn{3}{|c|}{18 days } \\
\hline & B & C & $\mathrm{O}$ & B & C & $\mathrm{O}$ & B & $\mathrm{C}$ & $\mathrm{O}$ & $\mathbf{B}$ & C & $\mathbf{O}$ \\
\hline Isopropylbenzene $\ldots \ldots \ldots \ldots \ldots$ & 10 & 0 & 0 & 20 & 0 & $\mathbf{0}$ & 30 & $\mathbf{0}$ & 0 & 50 & 0 & 0 \\
\hline Diisopropylbenzene........... & 20 & 5 & $\mathbf{0}$ & 30 & $\mathbf{5}$ & 0 & 60 & $\mathbf{5}$ & 0 & 70 & $\mathbf{5}$ & $\mathbf{0}$ \\
\hline Triisopropylbenzene........... & 50 & 10 & 0 & 80 & 15 & 0 & 95 & 15 & 0 & 100 & 15 & 0 \\
\hline Tetraisopropylbenzene..... & 40 & 15 & 0 & 50 & 20 & 0 & 60 & 20 & 0 & 80 & 20 & $\mathbf{0}$ \\
\hline Cymene..................... & 10 & 10 & 0 & 15 & 15 & 0 & 25 & 15 & 0 & 40 & 15 & $\mathbf{0}$ \\
\hline Methylcyclopentane ...... & 10 & 10 & 0 & 20 & 10 & 0 & 40 & 10 & 0 & 40 & 10 & $\mathbf{0}$ \\
\hline
\end{tabular}

* The pure aliphatic compounds $n$-hexane, neohexane, isooctane, and $n$-cetane, tested at the same time, produced no toxicity within the 18-day observation period.

ready indicated, however, this fraction is just on the limit with respect to its gravity rating; a lighter fraction would be more selective and hence safer to use from the herbicidal standpoint. But the fact that it would also be more volatile, and hence more inflammable, should not be overlooked.

Toxicity of Benzenes. Table 41 shows the results of spraying flax, barley, and carrot cultures with benzene, ethylbenzene, and diethylbenzene, used pure or diluted with the heavy isoparaffinic fraction. The toxicity seems to increase with increased substitution of ethyl groups through this series. Except at the lowest concentrations, these compounds show little selectivity.

The next tests involved a series of higher-boiling-point aromatic hydrocarbons. Pure samples of iso-, diiso-, triiso-, and tetraisopropylbenzene, mixed with the isoparaffinic diluent, were sprayed on barley, onions, and carrots. Included in the experiment also were cymene and methylcyclopentane. $n$ Hexane, neohexane, isooctane, and $n$-cetane were used without dilution; being aliphatic hydrocarbons, they offer promise as nontoxic diluents.

Table 42 presents the results of the tests. Among the substituted benzenes there was an increase in toxicity with increase in isopropyl substitutions up to 
the triisopropyl compound and then a small decrease with the tetraisopropyl compound. All toxicity was chronic, and the cymene and methylcyclopentane samples also showed toxicity. Because the isoparaffin used as a diluent in these tests also exhibits some chronic toxicity, the absolute level of toxicity is somewhat in doubt. The differences are significant because the concentrations are the same : table 42 reports results with 20 per cent concentrations of these toxicants. The experiments included 10 per cent concentrations as well, and these showed some toxicity. Such results contrast with those of tables 38 and 40 , where concentrations of toxicants in the range of 25 per cent

TABLE 43

TOXICITY OF ISOPROPYL AND DIISOPROPYLBENZENES TO BARLEY ; JUNE 22, 1944

\begin{tabular}{|c|c|c|c|c|c|}
\hline \multirow{2}{*}{$\begin{array}{l}\text { Oil and amounts of oil }(O) \\
\text { and diluent } \\
\text { (isoparaffin) applied per culture }\end{array}$} & \multicolumn{5}{|c|}{ Injury to barley, in per cent } \\
\hline & 1 day & 2 days & 3 days & 4 days & 6 days \\
\hline \multicolumn{6}{|l|}{ Isopropylbenzene: } \\
\hline $10 \mathrm{ml} \mathrm{O,0} \mathrm{ml} \mathrm{IP.}$ & 95 & .95 & 95 & 95 & 98 \\
\hline $8 \mathrm{ml} \mathrm{O}, 2 \mathrm{ml} \mathrm{IP..}$ & 80 & 80 & 80 & 80 & 85 \\
\hline $6 \mathrm{ml} \mathrm{O}, 4 \mathrm{ml} \mathrm{IP...}$ & 70 & 70 & 70 & 70 & 80 \\
\hline $4 \mathrm{ml} \mathrm{O}, 6 \mathrm{ml} \mathrm{IP...}$ & 50 & 60 & 60 & 70 & 80 \\
\hline $2 \mathrm{ml} \mathrm{O}, 8 \mathrm{ml} \mathrm{IP....}$ & 0 & 10 & 10 & 10 & 15 \\
\hline $0 \mathrm{ml} \mathrm{O}, 10 \mathrm{ml} \mathrm{IP....}$ & 0 & 0 & 0 & $\mathbf{0}$ & 0 \\
\hline \multicolumn{6}{|l|}{ Diisopropylbenzene: } \\
\hline $10 \mathrm{ml} \mathrm{O,0} \mathrm{ml} \mathrm{IP} \ldots$ & 100 & 100 & 100 & 100 & 100 \\
\hline $8 \mathrm{ml} \mathrm{O}, 2 \mathrm{ml} \mathrm{IP........}$ & 100 & 100 & 100 & 100 & 100 \\
\hline $6 \mathrm{ml} \mathrm{O}, 4 \mathrm{ml} \mathrm{IP} \ldots \ldots \ldots \ldots$ & 95 & 95 & 97 & 97 & 100 \\
\hline $4 \mathrm{ml} \mathrm{O}, 6 \mathrm{ml} \mathrm{IP..........}$ & 50 & 70 & 80 & 85 & 95 \\
\hline 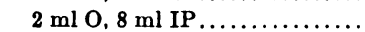 & 10 & 15 & 15 & 20 & 25 \\
\hline $0 \mathrm{ml} \mathrm{O}, 10 \mathrm{ml} \mathrm{IP.............}$ & 0 & 0 & 0 & 0 & 0 \\
\hline
\end{tabular}

to 0 per cent showed no toxicity. Apparently the toxicants in table 42 more nearly resemble those of petroleum fractions in effectiveness than do benzene, toluene, and xylene.

The four chemically pure aliphatic hydrocarbons were nontoxic throughout the 18-day period of observation. The hexanes were so volatile that when applied with the atomizer they did not even wet the plants. The octane was scarcely more effective. The $n$-cetane wet the plants thoroughly, and they appeared oil-soaked for over a week; but still there were no injury symptoms beyond a stunting of the plants. Later experiments, carried on for longer periods proved that even $n$-cetane is toxic to grass species. Evidently, chemically pure samples of these aliphatic hydrocarbons are the safest diluents available since even highly refined samples of petroleum fractions have proved more toxic.

Methylcyclopentane is a saturated ring compound, and one might presume that it would not be toxic. The test, however, proved that it was of about the same order of toxicity to carrots as triisopropylbenzene and almost as toxic to barley as isopropylbenzene. Cymene was about as toxic as methylcyclopentane. Lack of toxicity of all these compounds to the onion cultures resulted from the fact that the plants were larger than those used in previous tests. As onions grow older, the leaves become tougher and more resistant to oil tox- 
icity, particularly as growth slows down and the plants approach maturity. The onions used in these tests had practically ceased to grow. The barley and carrot cultures were also relatively mature.

The next test on pure compounds involved a comparison of iso- and diisopropylbenzenes in concentration series, with isoparaffin as a diluent. The tri- and tetraisopropylbenzenes were not available at the time in sufficient quantities for this test. Table 43 presents the data.

\section{TABLE 44}

Toxicity Tests of Aromatic and Cyclic Hydrocarbons on Broad-leaved Weeds AND GRASS; OCTOBER 30, 1944

\begin{tabular}{|c|c|c|c|c|c|c|c|c|c|c|c|c|}
\hline \multirow{3}{*}{ Concentration and compound } & \multicolumn{12}{|c|}{$\begin{array}{l}\text { Injury to broad-leaved weeds (BW) and grass (G), } \\
\text { in per cent }\end{array}$} \\
\hline & \multicolumn{2}{|c|}{1 day } & \multicolumn{2}{|c|}{2 days } & \multicolumn{2}{|c|}{3 days } & \multicolumn{2}{|c|}{4 days } & \multicolumn{2}{|c|}{6 days } & \multicolumn{2}{|c|}{8 days } \\
\hline & BW & G & BW & G & BW & G & $\mathrm{BW}$ & G & BW & G & BW & G \\
\hline \multicolumn{13}{|l|}{20 per cent concentration in isoparaffin: } \\
\hline Isopropylbenzene................ & 20 & 0 & 25 & 0 & 20 & $\mathbf{5}$ & 20 & 5 & 25 & 10 & 25 & 25 \\
\hline Diisopropylbenzene......... & 30 & 0 & 50 & 5 & 60 & 10 & 70 & 15 & 80 & 20 & 80 & 60 \\
\hline Triisopropylbenzene.... & 5 & 0 & 0 & 0 & 0 & 0 & 0 & 0 & 0 & 25 & 10 & 75 \\
\hline Tetraisopropylbenzene..... & 40 & 10 & 60 & 25 & 70 & 25 & 75 & 30 & 85 & 40 & 85 & 75 \\
\hline Methylcyclopentane ........... & 5 & 0 & 10 & 0 & 10 & 0 & 10 & 0 & 10 & $\mathbf{5}$ & 10 & 15 \\
\hline Cyclohexane........... & 20 & 0 & 75 & 40 & 85 & 40 & 90 & 50 & 90 & 65 & 90 & 75 \\
\hline Methylcyclohexane....... & 20 & 0 & 25 & 5 & 25 & 5 & 25 & 10 & 25 & 15 & 25 & 25 \\
\hline Cymene......................... & 2 & 0 & $\mathbf{5}$ & 0 & 10 & 5 & 15 & 5 & 20 & 10 & 20 & 15 \\
\hline \multicolumn{13}{|l|}{10 per cent concentration in isoparaffin: } \\
\hline Isopropylbenzene................. & $\mathbf{5}$ & 0 & $\mathbf{5}$ & 0 & $\mathbf{5}$ & 0 & $\mathbf{5}$ & 0 & 5 & 5 & $\mathbf{5}$ & 15 \\
\hline Diisopropylbenzene..... & 10 & 0 & 10 & 0 & 10 & 0 & 15 & 0 & 15 & $\mathbf{5}$ & 15 & 15 \\
\hline Triisopropylbenzene.... & 2 & 0 & 0 & 0 & 0 & 0 & 0 & 0 & 0 & 10 & $\mathbf{5}$ & 50 \\
\hline Tetraisopropylbenzene... & 20 & 5 & 20 & 5 & 20 & 10 & 20 & 15 & 40 & 20 & 40 & 75 \\
\hline Methylcyclopentane ... & 2 & 0 & 5 & 0 & $\mathbf{5}$ & 0 & $\mathbf{5}$ & 0 & 10 & $\mathbf{5}$ & 10 & 15 \\
\hline Cyclohexane.......... & 20 & 0 & 40 & $\mathbf{5}$ & 40 & 10 & 60 & 20 & 70 & 30 & 70 & 50 \\
\hline Methylcyclohexane. & 10 & 0 & 15 & 0 & 15 & 0 & 15 & 0 & 15 & $\mathbf{5}$ & 15 & 10 \\
\hline Cymene............. & 0 & 0 & 2 & 0 & 2 & 0 & 2 & 0 & $\mathbf{5}$ & 5 & $\mathbf{5}$ & 15 \\
\hline
\end{tabular}

These results confirm the implication that toxicity increases with additional substitutions, the diisopropyl compound proving the more toxic. Since the barley plants were young and succulent, acute toxicity was much more in evidence. The less concentrated mixtures became appreciably more toxic, however, during the 6-day observation period; and had the tests been continued longer, toxicity would undoubtedly have increased even further.

Aromatic and Cyclic Hydrocarbons. In one additional test conducted on these compounds, the four isopropyl-substituted benzenes and methylcyclopentane, cyclohexane, methylcyclohexane, and cymene were compared, all at 10 and 20 per cent concentrations in isoparaffin. Table 44 gives the data on these tests.

Judging from the results of this experiment, toxicity of the substituted benzenes increases with increasing number of substitutions, but not in a simple series ; the mono- and tri-substitutions are low in toxicity ; the di- and tetrasubstitutions are high. Since the limited samples supplied were used up in these tests and since isoparaffin had to be used as a diluent, no further testing was done with them. 
Cyclohexane proved more toxic than methylcyclohexane; methylcyclopentane and cymene again were comparable in toxicity and below the 6 -carbon ring compounds mentioned above.

\section{TABLE 45}

Toxicity Tests with Aromatic Hydrocarbons on Broad-Leaved Weeds AND GRASS; OCTOBER 30, 1944

\begin{tabular}{|c|c|c|c|c|c|c|c|c|c|c|c|c|}
\hline \multirow{3}{*}{ Concentration and compound } & \multicolumn{12}{|c|}{$\begin{array}{l}\text { Injury to broad-leaved weeds (BW) and grass (G), } \\
\text { in per cent }\end{array}$} \\
\hline & \multicolumn{2}{|c|}{1 day } & \multicolumn{2}{|c|}{2 days } & \multicolumn{2}{|c|}{3 days } & \multicolumn{2}{|c|}{4 days } & \multicolumn{2}{|c|}{6 days } & \multicolumn{2}{|c|}{8 days } \\
\hline & BW & $\mathrm{G}$ & BW & $\mathrm{G}$ & BW & $\mathbf{G}$ & BW & $\mathbf{G}$ & BW & $\mathrm{G}$ & BW & G \\
\hline \multicolumn{13}{|l|}{40 per cent concentration in isoparaffin: } \\
\hline 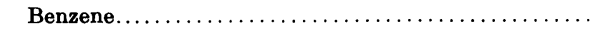 & $\mathbf{5}$ & 0 & 5 & 0 & 5 & 0 & 5 & 0 & $\mathbf{5}$ & $\mathbf{5}$ & $\mathbf{5}$ & 15 \\
\hline Toluene.................... & 0 & 0 & 0 & 0 & 0 & 0 & 0 & 0 & 0 & 0 & 0 & $\mathbf{5}$ \\
\hline Ethylbenzene $\ldots \ldots \ldots \ldots \ldots \ldots \ldots \ldots$ & 10 & 0 & 10 & 0 & 20 & 0 & 20 & 0 & 20 & 5 & 20 & 25 \\
\hline Xylene $\ldots \ldots \ldots \ldots \ldots \ldots \ldots \ldots \ldots \ldots \ldots \ldots$ & 20 & 5 & 10 & 0 & 10 & 0 & 15 & 0 & 15 & 5 & 15 & 15 \\
\hline \multicolumn{13}{|l|}{20 per cent concentration in isoparaffin: } \\
\hline 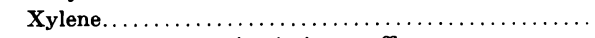 & 0 & 0 & 2 & 0 & 2 & 0 & 2 & $\mathrm{Oa}_{4}$ & 2 & 0 & 2 & 15 \\
\hline \multicolumn{13}{|l|}{10 per cent concentration in isoparaffin: } \\
\hline 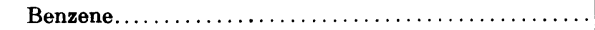 & 0 & 0 & 0 & 0 & 0 & 0 & 0 & 0 & 0 & 2 & 0 & 15 \\
\hline 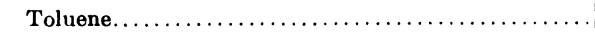 & 0 & 0 & 0 & 0 & 0 & 0 & 0 & 0 & 0 & 0 & 0 & 15 \\
\hline Ethylbenzene $\ldots \ldots \ldots \ldots \ldots \ldots \ldots \ldots \ldots \ldots \ldots \ldots$ & 0 & 0 & 0 & 0 & 0 & 0 & 0 & 0 & 5 & 5 & 5 & 15 \\
\hline 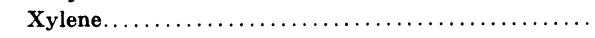 & 0 & 0 & 0 & 0 & 0 & 0 & $\mathbf{0}$ & 0 & 0 & 0 & 0 & 15 \\
\hline
\end{tabular}

TABLE 46

Toxicity of Cyclohfyane and Cyclohexene to Flax, Barlex, and Carrots; JANUARY 15, 1946

\begin{tabular}{|c|c|c|c|c|c|c|c|c|c|}
\hline \multirow{3}{*}{$\begin{array}{c}\text { Oil and amounts of oil }(O) \text { and diluent (isoparaffin) } \\
\text { applied per culture }\end{array}$} & \multicolumn{9}{|c|}{ Injury to flax (F), barley (B), and carrots (C), in per cent } \\
\hline & \multicolumn{3}{|c|}{1 day } & \multicolumn{3}{|c|}{2 days } & \multicolumn{3}{|c|}{3 days } \\
\hline & $\mathrm{F}$ & B & $\mathrm{C}$ & $\mathrm{F}$ & $\mathbf{B}$ & $\mathbf{C}$ & F & $\mathbf{B}$ & C \\
\hline \multicolumn{10}{|l|}{ Cyclohexane: } \\
\hline $8 \mathrm{ml} \mathrm{O}, 0 \mathrm{ml} \mathrm{IP} \ldots \ldots \ldots \ldots \ldots \ldots \ldots \ldots \ldots \ldots$ & 75 & 40 & 20 & 60 & 30 & 20 & 40 & 25 & 20 \\
\hline $6 \mathrm{ml} \mathrm{O}, 2 \mathrm{ml} \mathrm{IP} \ldots \ldots \ldots \ldots \ldots \ldots \ldots \ldots \ldots \ldots$ & 10 & $\mathbf{0}$ & 5 & 10 & 5 & $\mathbf{5}$ & 10 & 10 & 5 \\
\hline $4 \mathrm{ml} \mathrm{O,4} \mathrm{ml} \mathrm{IP} \ldots \ldots \ldots \ldots \ldots \ldots \ldots \ldots \ldots$ & $\mathbf{5}$ & 0 & 5 & $\mathbf{5}$ & 15 & 0 & $\mathbf{5}$ & 25 & 10 \\
\hline $2 \mathrm{ml} \mathrm{0,6} \mathrm{ml} \mathrm{IP} \ldots \ldots \ldots \ldots \ldots \ldots \ldots \ldots \ldots \ldots$ & 5 & $\mathbf{0}$ & $\mathbf{0}$ & 15 & 20 & 0 & 40 & 60 & 10 \\
\hline \multicolumn{10}{|l|}{ Cyclohexene: } \\
\hline $8 \mathrm{ml} \mathrm{O,0} \mathrm{ml} \mathrm{IP..}$ & 95 & 70 & 40 & $\theta 0$ & 70 & 40 & 90 & 70 & 40 \\
\hline $6 \mathrm{ml} \mathrm{O,2} \mathrm{ml} \mathrm{IP....}$ & 90 & 50 & 20 & 90 & 65 & 20 & 90 & 80 & 25 \\
\hline $4 \mathrm{ml} \mathrm{O}, 4 \mathrm{ml} \mathrm{IP} \ldots \ldots \ldots$ & 50 & 15 & $\mathbf{0}$ & 50 & 80 & 10 & 80 & 90 & 15 \\
\hline $2 \mathrm{ml} \mathrm{O}, 6 \mathrm{ml} \mathrm{IP} \ldots \ldots \ldots \ldots$ & 10 & 0 & 0 & 75 & 90 & 15 & 80 & 90 & 15 \\
\hline
\end{tabular}

Table 45, presenting tests run simultaneously with those of table 44, shows that ethylbenzene is comparable with xylene in toxicity. Their boiling points are nearly the same, the former being a bit lighter. The pure aliphatic hydrocarbons, $n$-hexane, neohexane, isooctane, and $n$-cetane proved nontoxic on these rather mature plants; apparently some oils may be used on certain plants without causing injury. 
Table 46 presents data on tests comparing cyclohexane and cyclohexene in pure and in concentration series, with isoparaffin as a diluent. The results show the cyclohexene to be the more toxic, the carrots being somewhat less susceptible to both compounds than were flax and barley. The heavy isoparaffinic fraction used as a diluent in this experiment had aged in a clear glass bottle and was itself somewhat toxic.

Mercaptans. The sulfur compounds present in most crude oils often constitute a problem because they are undesirable in refined products. They include the mercaptans, a group of foul-smelling liquids that might offer herbicidal possibilities. Samples of $n$-propyl, isopropyl, $n$-butyl, and isobutyl mercaptans have been tested. Used pure, these compounds caused almost

\section{TABLE 47}

Toxicity of Some Mercaptans to Barley, Foxtall Grass, Mustard, Carrots, aNd FlaX; March 8, 1945

\begin{tabular}{|c|c|c|c|c|c|c|c|c|c|c|c|c|c|c|c|c|c|c|c|c|}
\hline \multirow{3}{*}{ Mercaptan } & \multicolumn{20}{|c|}{ Injury to barley (B), foxtail grass ( $F x)$, mustard $(M)$, carrots $(C)$, and flax (F), in per cent } \\
\hline & \multicolumn{5}{|c|}{6 hours } & \multicolumn{5}{|c|}{1 day } & \multicolumn{5}{|c|}{4 days } & \multicolumn{5}{|c|}{6 days } \\
\hline & B & $\mathbf{F x}$ & $\mathbf{M}$ & $\mathbf{C}$ & $\mathbf{F}$ & B & $\mathbf{F x}$ & $\mathbf{M}$ & C & $\mathbf{F}$ & B & $\mathbf{F x}$ & $\mathbf{M}$ & $\mathbf{C}$ & $\mathbf{F}$ & $\mathbf{B}$ & $\mathbf{F x}$ & $\mathbf{M}$ & $\mathbf{C}$ & F \\
\hline$n$-Propyl... & 5 & 15 & 35 & 10 & 15 & 5 & 10 & 40 & 10 & 20 & 5 & 10 & 35 & 0 & 20 & 0 & 5 & 30 & 0 & 20 \\
\hline Isopropyl. . & 0 & 0 & 15 & 0 & 5 & 0 & 0 & 20 & 0 & 5 & 0 & 0 & 10 & 0 & 5 & 0 & 0 & 10 & 0 & 5 \\
\hline$n$-Butyl... & $\mathbf{5}$ & 25 & 50 & 10 & 25 & 5 & 20 & 30 & 15 & 20 & 5 & 15 & 35 & 5 & 20 & 5 & 15 & 25 & 0 & 15 \\
\hline Isobutyl... & 5 & 2 & 20 & 15 & 2 & 5 & 0 & 40 & 15 & 0 & 0 & 0 & 30 & 5 & 0 & 0 & 0 & 25 & 0 & 0 \\
\hline
\end{tabular}

immediate injury to leaves. They quickly evaporated, however, and little injury occurred after they had left the leaves of the test plants.

Table 47 presents the results. The normal compounds were somewhat more toxic than the branched-chain compounds. There were no significant differences between propyl and butyl compounds. None of these compounds was toxic enough to offer any promise as a herbicide. In 50:50 dilutions with isoparaffin, almost no toxicity was shown.

Tests on Chain and Cyclic Hydrocarbons. Since the odorless kerosene and the isoparaffinic fractions tested as nontoxic diluents had both proved toxic in experiments covering several days (p. 99), a test was conducted using $n$-cetane, hexane, and samples of the unsulfonated residues of stove oil and of isoparaffin that had been stored in the light. Cyclohexene was included as a toxic compound for comparison. The test ran over 5 weeks. Table 48 presents the results.

Cyclohexene is a very light hydrocarbon. It severely damaged all three crops and killed the flax completely. The effects on barley and carrots were not permanent. $n$-Hexane also caused some acute injury, from which all plants recovered.

Of the unsulfonated residues, that of the isoparaffin severely damaged flax and barley but proved nontoxic to carrots. The stove-oil residue, in contrast, lacked acute toxicity; but the barley manifested chronic injury and finally died. 
$n$-Cetane killed none of the plants. After about 2 weeks, however, the flax leaves began to show deformation at the tips, and the barley was stunted and tillered more heavily than did unsprayed checks. These effects persisted, the flax plants having their tip leaves clustered and folded as shown in figure $3, B$ (p. 97). But the growing points were not killed; and by the end of the experiment the injured region, visible as a whorl of distorted leaves, had been left behind as normal growth proceeded.

TABLE 48

Toxicity of $n$-Cetane, $n$-Hexane, Cyclohexene, and the Unsulfonated Residues of Stove Oil and Heavy Isoparaffin to Flax, Barlex, and Carrots;

NOVEMBER 9, 1945

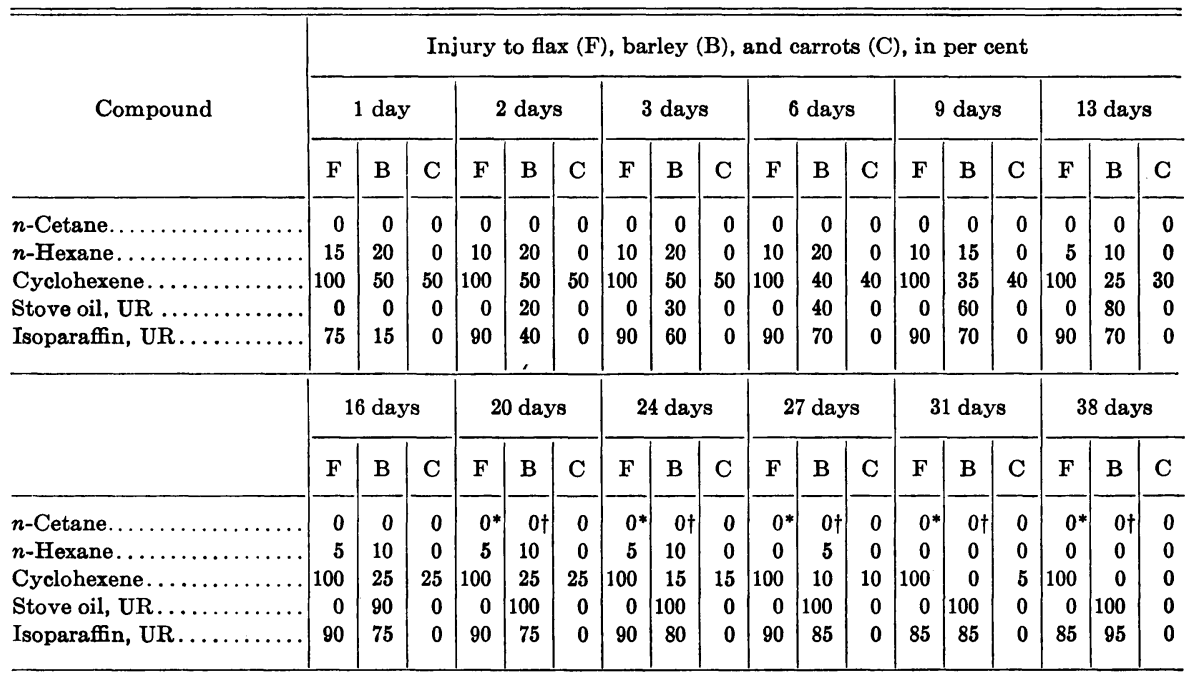

* Tip leaves deformed.

† Plants oil-soaked, stunted, and severely infected with powdery mildew.

The cetane-sprayed barley plants continued to be stunted. They appeared dark green and oil-soaked; during the final 2 weeks, they became heavily infected with mildew. Judging from these results, no diluent so far tested has been completely satisfactory. For short-time tests on fairly mature plants (see table 45) $n$-hexane, isooctane, and $n$-cetane proved nontoxic. On young succulent plants of susceptible species, however (table 48), these compounds appear toxic, the lighter ones producing acute toxicity, the heavier a slowdeveloping chronic injury. At present no completely nontoxic oil is known that ean be used under a wide range of conditions as a diluent for oil-spray experiments. Even unsulfonated residues of relatively nontoxic isoparaffin develop toxicity if stored in the light.

\section{SELECTIVITY OF OILS}

Because this study was initiated in response to questions on the specificity of oils, and because most tests were run with two or more species of test plants, some evidence of selectivity is to be found in almost every table. Some that 
warrant reinspection are $3,4,5,6,8,10,15,17,20,21,23,28,29,30,31,32,34$, $35,36,37,40,41,42,46,47$, and 48 .

Type of Compound. Considering, first, the type of compound responsible for selectivity, table 40 (p. 122) shows that xylene will severely injure grass at a concentration that scarcely harms carrots. Table 49 gives confirming evidence over a more extended observation period. Table 50 indicates that onions and flax may also tolerate low concentrations of aromaties.

TABLE 49

Toxicity of Xylene and Isoparaffin Mixtures to Carrots, Mustard, and FoxtaIl Grass; March 14, 1945

\begin{tabular}{|c|c|c|c|c|c|c|c|c|c|c|c|c|}
\hline \multirow{3}{*}{$\begin{array}{l}\text { Amounts of xylene } \\
\text { and diluent (isoparaffin) } \\
\text { applied per culture }\end{array}$} & \multicolumn{12}{|c|}{ Injury to carrots $(C)$, mustard $(M)$, and foxtail grass $(F x)$, in per cent } \\
\hline & \multicolumn{3}{|c|}{1 day } & \multicolumn{3}{|c|}{2 days } & \multicolumn{3}{|c|}{3 days } & \multicolumn{3}{|c|}{4 days } \\
\hline & C & $\mathbf{M}$ & $F_{x}$ & C & M & $F_{x}$ & C & $\mathbf{M}$ & $F x$ & $\mathrm{C}$ & $\mathbf{M}$ & $F_{x}$ \\
\hline 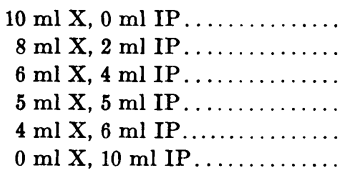 & $\begin{array}{r}95 \\
90 \\
80 \\
20 \\
5 \\
0\end{array}$ & $\begin{array}{r}100 \\
95 \\
95 \\
95 \\
95 \\
0\end{array}$ & $\begin{array}{r}100 \\
100 \\
95 \\
90 \\
75 \\
0\end{array}$ & $\begin{array}{r}100 \\
95 \\
85 \\
25 \\
5 \\
0\end{array}$ & $\begin{array}{r}100 \\
100 \\
95 \\
95 \\
95 \\
0\end{array}$ & $\begin{array}{r}100 \\
100 \\
95 \\
95 \\
80 \\
0\end{array}$ & $\begin{array}{r}100 \\
95 \\
85 \\
35 \\
5 \\
0\end{array}$ & $\begin{array}{r}100 \\
100 \\
100 \\
95 \\
95 \\
0\end{array}$ & $\begin{array}{r}100 \\
100 \\
98 \\
98 \\
90 \\
0\end{array}$ & $\begin{array}{r}100 \\
95 \\
85 \\
40 \\
5 \\
0\end{array}$ & $\begin{array}{r}100 \\
100 \\
100 \\
95 \\
95 \\
0\end{array}$ & $\begin{array}{r}100 \\
100 \\
98 \\
98 \\
95 \\
0\end{array}$ \\
\hline \multirow{2}{*}{$0 \mathrm{ml} \mathrm{X}, 10 \mathrm{ml} \mathrm{IP... \ldots \ldots \ldots ....}$} & \multicolumn{3}{|c|}{6 days } & \multicolumn{3}{|c|}{8 days } & \multicolumn{3}{|c|}{13 days } & \multicolumn{3}{|c|}{18 days } \\
\hline & $\mathrm{C}$ & $\mathbf{M}$ & $\mathrm{Fx}$ & $\mathrm{C}$ & $\mathbf{M}$ & $\mathbf{F x}$ & $\mathrm{C}$ & M & $\mathrm{Fx}$ & $\mathrm{C}$ & $\mathbf{M}$ & $\mathbf{F x}$ \\
\hline 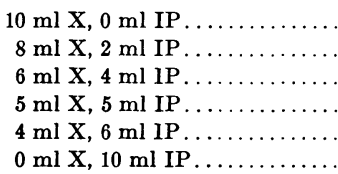 & $\begin{array}{r}100 \\
90 \\
75 \\
40 \\
5 \\
0\end{array}$ & $\begin{array}{r}100 \\
100 \\
100 \\
95 \\
98 \\
0\end{array}$ & $\begin{array}{r}100 \\
100 \\
95 \\
100 \\
95 \\
0\end{array}$ & $\begin{array}{r}100 \\
90 \\
75 \\
40 \\
5 \\
0\end{array}$ & $\begin{array}{r}100 \\
100 \\
100 \\
100 \\
98 \\
0\end{array}$ & $\begin{array}{r}100 \\
100 \\
95 \\
100 \\
98 \\
5\end{array}$ & $\begin{array}{r}100 \\
80 \\
70 \\
30 \\
0 \\
0\end{array}$ & $\begin{array}{r}100 \\
100 \\
100 \\
98 \\
98 \\
0\end{array}$ & $\begin{array}{r}98 \\
99 \\
98 \\
100 \\
98 \\
10\end{array}$ & $\begin{array}{r}100 \\
60 \\
50 \\
15 \\
0 \\
0\end{array}$ & $\begin{array}{r}100 \\
100 \\
100 \\
98 \\
95 \\
0\end{array}$ & $\begin{array}{r}98 \\
99 \\
98 \\
100 \\
99 \\
10\end{array}$ \\
\hline
\end{tabular}

Table 42 (p. 123) shows that the isopropyl-substituted benzenes are somewhat selective, but that they injure carrots more than do such petroleum fractions as gasoline and stove oil. Toxicity of the isopropylbenzenes is chronic and results with Diesel oil (compare table 4, p. 87) show that the chronic toxicants exhibit less selectivity between weeds and carrots than do compounds causing acute toxicity.

There is apparently a relation between boiling point of a toxicant, type of toxicity, and selectivity. Table 10 (p. 98) compares two kerosenes and mineral seal oil. The latter appeared relatively nontoxic for the first week; but plants gradually developed injury until, after 24 days, all were severely affected. A significant fact is that carrots were damaged more than grass. Tests on carrots with the fuel oil used in the tests on grasses reported in table 12 (p. 99) proved that this heavy crude fraction has similar chronic toxic properties.

As shown by table 10 (p. 98), when kerosene was applied the grass was dead after 24 days, whereas broad-leaved weeds, carrots, and flax were unharmed. This result, which has been obtained many times, indicates a possible 
TABLE 50

Toxicity of Xylene, and Xylene and Odorless Kerosene Mixtures to Flax, Onions, Carrots, Grasses, AND Broad-LeAved WeEdS ; A PRIL 12, 1944

\begin{tabular}{|c|c|c|c|c|c|c|c|c|c|c|c|c|c|c|c|}
\hline \multirow{3}{*}{$\begin{array}{l}\text { Amounts of xylene and } \\
\text { diluent (odorless kerosene) } \\
\text { applied per culture }\end{array}$} & \multicolumn{15}{|c|}{$\begin{array}{l}\text { Injury to flax }(\mathrm{F}) \text {, onions }(\mathrm{O}) \text {, carrots }(\mathrm{C}) \text {, grasses }(\mathrm{G}) \text {, and broad-leaved weeds }(\mathrm{BW}) \text {, } \\
\text { in per cent }\end{array}$} \\
\hline & \multicolumn{5}{|c|}{1 day } & \multicolumn{5}{|c|}{2 days } & \multicolumn{5}{|c|}{3 days } \\
\hline & $\mathrm{F}$ & 0 & C & G & $\mathrm{BW}$ & F & 0 & $\mathrm{C}$ & G & $\mathrm{BW}$ & F & o & C & G & BW \\
\hline $\begin{array}{r}10 \mathrm{ml} \mathrm{X}, 0 \mathrm{ml} \mathrm{OK} \ldots \ldots \ldots \\
7.5 \mathrm{ml} \mathrm{X}, 2.5 \mathrm{ml} \mathrm{OK} \ldots \ldots \\
5.0 \mathrm{ml} \mathrm{X}, 5.0 \mathrm{ml} \mathrm{OK} \ldots \ldots \\
2.5 \mathrm{ml} \mathrm{X}, 7.5 \mathrm{ml} \mathrm{OK} \ldots \ldots\end{array}$ & $\begin{array}{r}100 \\
90 \\
75 \\
0\end{array}$ & $\begin{array}{r}50 \\
50 \\
20 \\
0\end{array}$ & $\begin{array}{r}90 \\
40 \\
0 \\
0\end{array}$ & $\begin{array}{l}75 \\
90 \\
90 \\
25\end{array}$ & $\begin{array}{l}90 \\
90 \\
75 \\
10\end{array}$ & $\begin{array}{r}100 \\
90 \\
75 \\
0\end{array}$ & $\begin{array}{r}50 \\
50 \\
20 \\
0\end{array}$ & $\begin{array}{r}90 \\
60 \\
0 \\
0\end{array}$ & $\begin{array}{l}90 \\
90 \\
90 \\
25\end{array}$ & $\begin{array}{l}90 \\
95 \\
80 \\
20\end{array}$ & $\begin{array}{r}100 \\
95 \\
75 \\
0\end{array}$ & $\begin{array}{r}50 \\
50 \\
20 \\
0\end{array}$ & $\begin{array}{r}95 \\
75 \\
0 \\
0\end{array}$ & $\begin{array}{l}90 \\
95 \\
95 \\
25\end{array}$ & $\begin{array}{l}90 \\
95 \\
90 \\
25\end{array}$ \\
\hline \multirow{2}{*}{$2.5 \mathrm{ml} \mathrm{X}, 7.5 \mathrm{ml} \mathrm{OK} \ldots \ldots$} & \multicolumn{5}{|c|}{7 days } & \multicolumn{5}{|c|}{12 days } & \multicolumn{5}{|c|}{17 days } \\
\hline & F & 0 & C & G & BW & F & 0 & C & G & $\mathrm{BW}$ & F & 0 & C & G & BW \\
\hline $\begin{array}{r}10 \mathrm{ml} \mathrm{X}, 0 \mathrm{ml} \mathrm{OK} \ldots . . \\
7.5 \mathrm{ml} \mathrm{X}, 2.5 \mathrm{ml} \mathrm{OK} . \\
5.0 \mathrm{ml} \mathrm{X}, 5.0 \mathrm{ml} \mathrm{OK} . \\
2.5 \mathrm{ml} \mathrm{X}, 7.5 \mathrm{ml} \mathrm{OK} .\end{array}$ & $\begin{array}{r}100 \\
100 \\
75 \\
0\end{array}$ & $\begin{array}{r}40 \\
50 \\
40 \\
0\end{array}$ & $\begin{array}{r}100 \\
90 \\
0 \\
0\end{array}$ & $\begin{array}{r}100 \\
100 \\
100 \\
50\end{array}$ & $\begin{array}{r}100 \\
100 \\
100 \\
25\end{array}$ & $\begin{array}{r}100 \\
100 \\
60 \\
0\end{array}$ & $\begin{array}{r}20 \\
50 \\
30 \\
0\end{array}$ & $\begin{array}{r}100 \\
90 \\
0 \\
0\end{array}$ & $\begin{array}{r}100 \\
100 \\
100 \\
75\end{array}$ & $\begin{array}{r}100 \\
100 \\
100 \\
25\end{array}$ & $\begin{array}{r}100 \\
100 \\
60 \\
0\end{array}$ & $\begin{array}{r}10 \\
50 \\
50 \\
0\end{array}$ & $\begin{array}{r}100 \\
90 \\
0 \\
0\end{array}$ & $\begin{array}{r}100 \\
100 \\
100 \\
75\end{array}$ & $\begin{array}{r}100 \\
100 \\
100 \\
25\end{array}$ \\
\hline
\end{tabular}

TABLE 51

Toxicity of Gasoline, Stove Oil, and Avon Weed Killer in Different Concentrations to Onions, Grass, and WeEds ; February 21, 1944

\begin{tabular}{|c|c|c|c|c|c|c|c|c|c|c|c|c|}
\hline \multirow{3}{*}{$\begin{array}{l}\text { Oil fraction and amounts of } \\
\text { fraction (F) and } \\
\text { diluent (odorless kerosene) } \\
\text { applied per culture }\end{array}$} & \multicolumn{12}{|c|}{ Injury to onions $(O)$, grass $(G)$, and weeds $(W)$, in per cent } \\
\hline & \multicolumn{3}{|c|}{2 days } & \multicolumn{3}{|c|}{3 days } & \multicolumn{3}{|c|}{4 days } & \multicolumn{3}{|c|}{5 days } \\
\hline & 0 & G & $\mathrm{w}$ & 0 & G & $\mathrm{w}$ & 0 & G & $\mathrm{W}$ & $\theta$ & G & $\mathrm{W}$ \\
\hline \multicolumn{13}{|l|}{ Gasoline: } \\
\hline $10 \mathrm{ml} \mathrm{F}, 0 \mathrm{ml} \mathrm{OK}$. & 60 & 90 & 75 & 60 & 95 & 90 & 60 & 99 & 90 & 50 & 100 & 90 \\
\hline $5 \mathrm{ml} \mathrm{F}, 5 \mathrm{ml} \mathrm{OK}$. & 0 & 0 & 25 & 0 & 0 & 25 & 0 & 0 & 25 & 0 & 0 & 25 \\
\hline $4 \mathrm{ml} \mathrm{F}, 6 \mathrm{ml} \mathrm{OK}$. & 0 & 0 & 10 & $\mathbf{0}$ & 0 & 10 & 0 & 0 & 10 & 0 & 0 & 10 \\
\hline $3 \mathrm{ml} \mathrm{F}, 7 \mathrm{ml} \mathrm{OK}$. & 0 & 0 & 5 & 0 & 0 & 5 & 0 & 0 & 5 & 0 & 0 & $\mathbf{5}$ \\
\hline $2 \mathrm{ml} \mathrm{F}, 8 \mathrm{ml} \mathrm{OK}$. & 0 & 0 & 0 & 0 & 0 & 0 & 0 & 0 & 0 & 0 & 0 & 0 \\
\hline \multicolumn{13}{|l|}{ Stove oil: } \\
\hline $10 \mathrm{ml} \mathrm{F}, 0 \mathrm{ml} \mathrm{OK}$ & 50 & 75 & 90 & 60 & 85 & 90 & 65 & 95 & 90 & 50 & 95 & 95 \\
\hline $5 \mathrm{ml} \mathrm{F}, 5 \mathrm{ml} \mathrm{OK}$. & 0 & 50 & 75 & 5 & 60 & 75 & 10 & 60 & 75 & 10 & 50 & 75 \\
\hline $4 \mathrm{ml} \mathrm{F}, 6 \mathrm{ml} \mathrm{OK}$. & 0 & 20 & 50 & 0 & 40 & 60 & 5 & 40 & 60 & 5 & 40 & 60 \\
\hline $3 \mathrm{ml} \mathrm{F}, 7 \mathrm{ml} \mathrm{OK}$. & 0 & 5 & 25 & 0 & 5 & 40 & 0 & 5 & 30 & 0 & 5 & 25 \\
\hline $2 \mathrm{ml} \mathrm{F}, 8 \mathrm{ml} \mathrm{OK}$. & 0 & 0 & 10 & 0 & 0 & 15 & 0 & 0 & 15 & 0 & 0 & 15 \\
\hline \multicolumn{13}{|l|}{ Avon Weed Killer: } \\
\hline $10 \mathrm{ml} \mathrm{F}, 0 \mathrm{ml}$ OK. & 100 & 100 & 100 & 100 & 100 & 100 & 100 & 100 & 100 & 100 & 100 & 100 \\
\hline $5 \mathrm{ml} \mathrm{F}, 5 \mathrm{ml} \mathrm{OK}$ & 90 & 95 & 100 & 95 & 100 & 100 & 100 & 100 & 100 & 100 & 100 & 100 \\
\hline $4 \mathrm{ml} \mathrm{F}, 6 \mathrm{ml} \mathrm{OK}$ & 80 & 90 & 95 & 75 & 100 & 100 & 100 & 100 & 100 & 100 & 100 & 100 \\
\hline $3 \mathrm{ml} \mathrm{F}, 7 \mathrm{ml} \mathrm{OK}$. & 50 & 75 & 90 & 50 & 100 & 100 & 50 & 100 & 100 & 50 & 100 & 100 \\
\hline $2 \mathrm{ml} \mathrm{F}, 8 \mathrm{ml} \mathrm{OK}$ & 0 & 20 & 30 & 10 & 50 & 75 & 15 & 25 & 80 & 10 & 50 & 80 \\
\hline
\end{tabular}


commercial application because wild oats, foxtail, and other grass species are serious pests in flax. Observations on many oil-spray results indicate that oils in the medium gravity range are specific against grasses. Even when used at concentrations that do not kill the grass plants, oils stunt these weeds and allow the crop to compete more successfully for light and moisture.

Experiments with heavy olefinic and aromatic fractions extracted from petroleum show these compounds to be selective between carrots and weeds (table 28, p. 110). Furthermore, these compounds are fatal to weeds at concentrations of 30 per cent and below. In this characteristic they resemble the naturally occurring selective toxicants of oils much more than do xylene and similar low-boiling simple aromatics.

TABLE 52

Toxicity of Gasoline and Stove Oil to Onions, Weeds, and Grass ; FerRuARy 25, 1944

\begin{tabular}{|c|c|c|c|c|c|c|c|c|c|c|c|c|}
\hline \multirow{3}{*}{$\begin{array}{l}\text { Oil fraction } \\
\text { and amounts applied } \\
\text { per culture }\end{array}$} & \multicolumn{12}{|c|}{ Injury to onions $(O)$, weeds $(W)$, and grass $(G)$, in per cent } \\
\hline & \multicolumn{3}{|c|}{1 day } & \multicolumn{3}{|c|}{3 days } & \multicolumn{3}{|c|}{5 days } & \multicolumn{3}{|c|}{10 days } \\
\hline & $\mathrm{O}$ & W & G & $\mathrm{O}$ & W & G & $\mathrm{O}$ & W & G & $\mathrm{O}$ & W & G \\
\hline Gasoline: & & & & & & & & & & & & \\
\hline $71 / 2 \mathrm{ml}$ & 20 & 95 & 90 & 20 & 100 & 90 & 20 & 100 & 100 & 10 & 100 & 100 \\
\hline $10 \mathrm{ml} \ldots$ & 50 & 100 & 95 & 40 & 100 & 98 & 40 & 100 & 100 & 20 & 100 & 100 \\
\hline $121 / 2 \mathrm{ml}$ & 50 & 100 & 95 & 40 & 100 & 100 & 40 & 100 & 100 & 20 & 100 & 100 \\
\hline $15 \mathrm{ml} \ldots$ & 70 & 100 & 100 & 60 & 100 & 100 & 60 & 100 & 100 & 60 & 100 & 100 \\
\hline Stove oil: & & & & & & & & & & & & \\
\hline $5 \mathrm{ml} .$. & 10 & 50 & 90 & 10 & 50 & 90 & 10 & 90 & 90 & 0 & 100 & 100 \\
\hline $71 / 2 \mathrm{ml}$. & 10 & 80 & 90 & 10 & 90 & 100 & 15 & 95 & 100 & 5 & 100 & 100 \\
\hline $10 \mathrm{ml} \ldots$ & 40 & 100 & 75 & 40 & 100 & 90 & 40 & 100 & 100 & 20 & 100 & 100 \\
\hline $121 / 2 \mathrm{ml} \ldots \ldots \ldots \ldots \ldots \ldots$ & 50 & 75 & 90 & 40 & 75 & 100 & 60 & 75 & 100 & 40 & 90 & 100 \\
\hline
\end{tabular}

According to table 28, the heavy aromatic fraction damaged foxtail grass slightly more than it did flax, a result that confirms the observations in table 10.

Selective Action on Onions. Table 51 compares the toxicities of gasoline, stove oil, and Avon Weed Killer at different concentrations with respect to onions, grass, and broad-leaved weeds. Judging from the results, stove oil has a selective action on weeds in onions. The dilutions of gasoline did not include concentrations between 100 per cent and 50 per cent. Other experiments show that at intermediate concentrations gasoline, too, is selective on onions.

These oils were used in sufficient volume to wet the plants thoroughly. A possible alternative approach to the problem was to apply the fractions in varying volumes, omitting the diluent. Table 52 gives the results of such an experiment. Evidently gasoline and stove oil both act selectively on weeds in onions.

Next, in a study of the possible relation between boiling point and selectivity, the experiments reported in table 53 were performed. These were some of the same fractions reported in table 5 (p. 92). Evidently the heavier fractions are more toxic to onions than are the light ones. The results, although 
less consistent than one might wish, do show that grass may be severely injured without harm to young onions and that injury to onions is greatest toward the heavy end. This indication is confirmed by results of field trials. By means of a knapsack sprayer, onions in the field were treated with gasoline, stove oil, and Diesel oil. These oils killed grasses and most broad-leaved weeds. Injury to the onions was negligible from gasoline, not bad from stove oil, but serious from Diesel oil (Crafts and Raynor, 1944).

TABLE 53

Toxicity of Fractional Distillates of White Gasoline and Stove Oil to Onions and Grasses; May 5, 1944

\begin{tabular}{|c|c|c|c|c|c|c|c|c|c|c|}
\hline \multirow{3}{*}{$\begin{array}{l}\text { Oil, fraction no. and amounts of fraction }(\mathrm{F}) \\
\text { and diluent } \\
\text { (isoparaffin) applied per culture }\end{array}$} & \multicolumn{10}{|c|}{ Injury to onions $(O)$ and grasses $(G)$, in per cent } \\
\hline & \multicolumn{2}{|c|}{1 day } & \multicolumn{2}{|c|}{3 days } & \multicolumn{2}{|c|}{5 days } & \multicolumn{2}{|c|}{10 days } & \multicolumn{2}{|c|}{15 days } \\
\hline & $\mathrm{O}$ & G & $\mathrm{O}$ & G & $\mathrm{O}$ & $\mathrm{G}$ & $\mathrm{O}$ & G & $\mathrm{O}$ & G \\
\hline \multicolumn{11}{|l|}{ White gasoline no. 1: } \\
\hline $12 \mathrm{ml} \mathrm{F}, 0 \mathrm{ml} \mathrm{IP...}$ & 20 & 90 & 10 & 90 & 5 & 90 & 0 & 90 & 0 & 95 \\
\hline $6 \mathrm{ml} \mathrm{F}, 6 \mathrm{ml} \mathrm{IP} \ldots$ & 0 & 10 & $\mathbf{0}$ & 10 & 0 & 10 & 0 & 20 & 0 & 25 \\
\hline \multicolumn{11}{|l|}{ White gasoline no. 2: } \\
\hline $12 \mathrm{ml} \mathrm{F}, 0 \mathrm{ml} \mathrm{IP} \ldots$ & 30 & 90 & 20 & 90 & 10 & 95 & 0 & 100 & 0 & 100 \\
\hline $6 \mathrm{ml} \mathrm{F}, 6 \mathrm{ml} \mathrm{IP} \ldots$ & 0 & 10 & 0 & 15 & 0 & 15 & 0 & 25 & 0 & 40 \\
\hline \multicolumn{11}{|l|}{ White gasoline no. 3 : } \\
\hline $12 \mathrm{ml} \mathrm{F}, 0 \mathrm{ml} \mathrm{IP...}$ & 50 & 95 & 50 & 100 & 40 & 100 & 40 & 100 & 50 & 100 \\
\hline $6 \mathrm{ml} \mathrm{F}, 6 \mathrm{ml} \mathrm{IP} \ldots$ & 10 & 50 & 10 & 60 & 5 & 75 & 0 & 90 & 0 & 90 \\
\hline \multicolumn{11}{|l|}{ White gasoline no. 4: } \\
\hline $12 \mathrm{ml} \mathrm{F}, 0 \mathrm{ml} \mathrm{IP...}$ & 65 & 95 & 60 & 100 & 50 & 100 & 30 & 100 & 20 & 100 \\
\hline $6 \mathrm{ml} \mathrm{F}, 6 \mathrm{ml} \mathrm{IP.}$ & 15 & 75 & 15 & 85 & 10 & 90 & 0 & 90 & 0 & 90 \\
\hline \multicolumn{11}{|l|}{ Stove oil no. 1: } \\
\hline $12 \mathrm{ml} \mathrm{F}, 0 \mathrm{ml}$ IP. & 70 & 90 & 60 & 90 & 50 & 90 & 25 & 100 & 15 & 100 \\
\hline $6 \mathrm{ml} \mathrm{F}, 6 \mathrm{ml} \mathrm{IP}$ & 10 & 40 & 10 & 50 & 5 & 50 & 0 & 50 & . 0 & 95 \\
\hline \multicolumn{11}{|l|}{ Stove oil no. 2: } \\
\hline $12 \mathrm{ml} \mathrm{F}, 0 \mathrm{ml} \mathrm{IP}$ & 60 & 95 & 70 & 95 & 75 & 95 & 85 & 100 & 100 & 100 \\
\hline $6 \mathrm{ml} \mathrm{F}, 6 \mathrm{ml} \mathrm{IP}$ & 10 & 90 & 10 & 90 & 0 & 95 & 0 & 95 & 0 & 95 \\
\hline \multicolumn{11}{|l|}{ Stove oil no. 3 : } \\
\hline $12 \mathrm{ml} \mathrm{F}, 0 \mathrm{ml} \mathrm{IP.}$ & 50 & 90 & 40 & 95 & 40 & 95 & 40 & 100 & 30 & 100 \\
\hline $6 \mathrm{ml} \mathrm{F}, 6 \mathrm{ml} \mathrm{IP.}$ & 10 & 80 & 10 & 80 & 0 & 90 & 0 & 90 & 0 & 95 \\
\hline \multicolumn{11}{|l|}{ Stove oil no. 4 : } \\
\hline $12 \mathrm{ml} \mathrm{F}, 0 \mathrm{ml} \mathrm{IP}$. & 60 & 80 & 50 & 90 & 40 & 90 & 50 & 100 & 75 & 100 \\
\hline $6 \mathrm{ml} \mathrm{F}, 6 \mathrm{ml} \mathrm{IP}$ & 10 & 70 & 10 & 70 & 0 & 75 & 0 & 75 & 0 & 75 \\
\hline
\end{tabular}

According to the experiments reported above, oils offer much promise as selective sprays in onions and flax, two crops not previously treated with such materials. Other selectivities may still exist unexplored by the experimental method. In one case observed, barley was killed in a culture containing wild mustard; this constitutes a reversal of the usual selectivity observed with dinitro sprays (Crafts, 1946).

Susceptibility of Weed Species to Selective Oils. As for selectivity with regard to weed species, mustard and fiddleneck are two of the most susceptible weeds; they are readily controlled with gasoline, stove oil, and Diesel oil. Pigweeds, goosefoot, and lambs'-quarters are somewhat more difficult to kill; sow thistle and wild lettuce are rather resistant to oil sprays. Dense matted stands of chickweed are very stubborn. Grasses, including the cultivated and 
wild cereals, are some of the most easily controlled weeds where oil sprays are used. In fact, the oils seem almost specific for grasses ; and where fractions as heavy as stove oil and kerosene are used, the slowly developing chronic toxicity will often kill grass species after several weeks where, for the first few days, they seemed almost unharmed. Because kerosene seems particularly capable of causing such chronic injury without harming onions, flax, mustard, and other plants, it should receive more detailed study as a selective herbicide.

\section{PHYSICAL PROPERTIES OF OIL AND APPLICATION METHODS}

Properties of Water and Oils. The two common types of liquids used as herbicidal sprays, namely aqueous solutions and oils, have contrasting physical properties. Water is a highly polar compound. Its boiling and melting points are much higher than would be expected from its composition ; its viscosity and surface tension are also extremely high.

The oils are much more usual in their physical properties. Their melting and boiling points and their viscosities are more commensurate with their molecular weights and composition; their surface tensions are only one third to one half that of water (table 54).

Plant surfaces are commonly cutinized or suberized. Cutin and suberin are fatty substances that resemble oils in their chemical affinities. For this reason aqueous sprays are repelled by most plant surfaces; they round up into spherical droplets and tend to run off. Even when atomized by high pressure and applied with great force, they do not readily stick to the waxy surfaces of many plants. If they do stick they stay in place or collect into droplets, presenting a minimum surface of contact.

Oils of the type used for weed spraying, being low in viscosity and surface tension and having affinities for fatty surfaces, wet plants rapidly and completely, tending to spread and to creep. They form thin films and move along plant surfaces, penetrating every crack and crevice. They gravitate downward so long as film thickness permits free movement; crowns of plants may be covered by oil that has been applied to foliage several inches above. Having covered the plant, an oil penetrates the cuticle and cell walls and comes into intimate contact with the cell protoplasm.

Properties of Plant Surfaces. Plants vary in structure, and certain reactions to aqueous and oil sprays reflect these differences. Most dicotyledonous plants have an open branching form with extended leaves and exposed growing regions. These plants, such as mustard and fiddleneck, are readily killed by aqueous sprays, even though their waxy surfaces are not easily wet. Grasses, on the other hand, have minutely ridged surfaces with waxy or siliceous coatings that repel water; their leaves are often vertical in position; and their growing regions are enclosed by the bases of older leaves. To penetrate such plants, oils have especially favorable properties. This may be one reason why oils tend to act as specific toxicants against grasses.

For reasons cited above, oils have proved invaluable for spraying grasses and mixed weeds along highways, railroads, and such places, where all weed growth is undesirable. Before World War II, the California highway system required the use of nearly a million gallons of Diesel oil per year for firebreak maintenance. 
Creeping of Oils. For a more accurate study of the part played by the creeping of oils, an experiment was set up to test oil toxicity on tissues not actually sprayed. Four cultures having barley plants about 10 inches in height were selected. The first was sprayed in an upright position in the usual manner, with $6 \mathrm{ml}$ of Diesel oil. Two others were laid on their sides; strings were tied around the plants at a level of 5 inches above the soil; and, with the lower halves shielded, the upper portions were sprayed until thoroughly saturated

TABLE 54

Some Physical Properties of Water, Oils, and Some COMMON ORganic Liquids

\begin{tabular}{|c|c|c|}
\hline Compound & $\begin{array}{l}\text { Boiling point, } \\
{ }^{\circ} \text { Centigrade }\end{array}$ & $\begin{array}{l}\text { Surface tension, } \\
\text { dynes per cm. } \\
\text { at } 20^{\circ} \mathrm{C}\end{array}$ \\
\hline \multicolumn{3}{|l|}{ Petroleum fractions: } \\
\hline Naphtha.......... & Up to 150 & $19-23$ \\
\hline Kerosenes............................. & $150-300$ & 23-32 \\
\hline Gas oils $\ldots \ldots \ldots \ldots \ldots \ldots \ldots \ldots \ldots \ldots \ldots \ldots \ldots \ldots \ldots \ldots \ldots$ & $250-325$ & $28-29$ \\
\hline Petroleum distillates* & Up to 100 & 19 \\
\hline Petroleum distillates*. & $100-150$ & 23 \\
\hline Petroleum distillates*. & $150-200$ & 25 \\
\hline Petroleum distillates*. & $200-250$ & 26.5 \\
\hline Petroleum distillates*. & $250-300$ & 28 \\
\hline \multicolumn{3}{|l|}{ Pure compounds: } \\
\hline Water....................... & 100.0 & $72.75 \pm .05$ \\
\hline Ethyl alcohol $\ldots \ldots \ldots \ldots \ldots \ldots \ldots \ldots \ldots \ldots \ldots \ldots \ldots \ldots \ldots \ldots$ & 78.5 & 22.27 \\
\hline Benzene. $\ldots \ldots \ldots \ldots \ldots \ldots \ldots \ldots \ldots \ldots \ldots \ldots \ldots$ & 79.6 & 28.88 \\
\hline 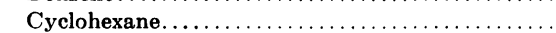 & 81.4 & 25.3 \\
\hline 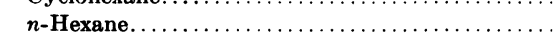 & 69.0 & 18.43 \\
\hline Toluene................................. & 110.5 & 28.43 \\
\hline Ethyl benzene............................ & 136.5 & 29.20 \\
\hline 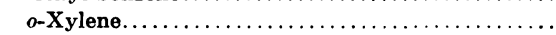 & 144.0 & 30.10 \\
\hline$m$-Xylene & 139.0 & 28.90 \\
\hline$p$-Xylene. . . & 137.7 & 28.37 \\
\hline 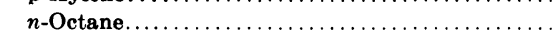 & 124.6 & 21.80 \\
\hline
\end{tabular}

* Estimated from fig. 3, p. 149, International Critical Tables.

with oil. One of these was then placed in an upright position; the other remained on its side. The fourth was left unsprayed, as a control.

As injury developed on these cultures, it became apparent that the creeping of the Diesel oil down the stems has an important bearing upon the results of spraying. Whereas the oil on the plants that remained in a horizontal position moved a maximum of 2 inches toward the soil, the plants that were sprayed on the top half and then placed upright died completely, and the odor of Diesel oil could be detected in the tissues at the crown. When the experiment was repeated and one culture completely inverted, there was even less creeping toward the crown than in the horizontal position. Observing the oil on the plant set upright, one could see the thin film spreading down the leaves and into the narrow crevice between the leaf base and the inner leaf which it surrounds. Within 24 hours after spraying, if the youngest leaf at the tip of the barley plant was pulled out, it was found to be dead at the region of the intercalary meristem. 
This experiment leads to several deductions regarding Diesel oil as a general contact herbicide :

1. After being applied as a spray, such an oil will creep at least 5 inches down the grass stems into the crown; the weeds will die even after a poor job of spraying ; whereas emulsions or aqueous sprays, because they lack the ability to creep, would only injure the regions actually hit.

\section{TABLE 55}

Experiments on the Efrects of Contact and Creeping of Oils on Toxicity To Barlex; JANUARY 8, 1945

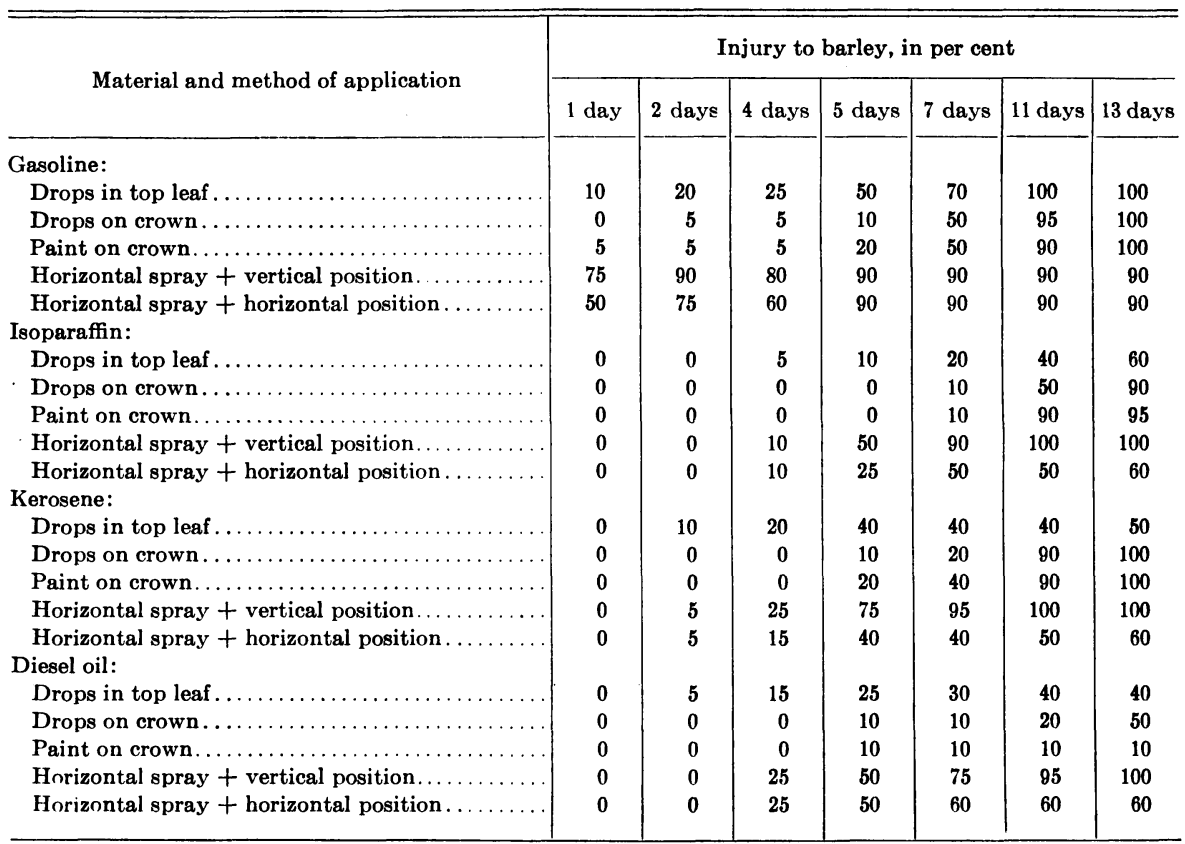

2. The oil is highly toxic : even the minute quantity present in the thin film will kill the meristematic region.

3 . Toxicity is largely chronic; acute toxicants, when present in such small quantities, are not potent enough to kill the tissues or they evaporate before killing is complete. These results largely explain the wide satisfaction given by Diesel oil as a general contact spray.

Role of Application Method. One further experiment was performed to compare the abilities of different oils to kill barley plants when various methods of application are used. In table 55, which presents the results, several points of interest may be noted. When the oil was applied by depositing several drops in the funnel formed by the top leaf, gasoline proved the most toxic. This finding reflects the intense acute activity of this oil. Penetrating rapidly, the gasoline evidently killed the meristematic region within a short time. Applied on the outside of the crown, or sprayed on, it evaporated before it had time to react with all the tissues. 
Isoparaffin was most effective when applied as a spray and allowed to run down into the crown. Killing was by slow chronic action. Kerosene was somewhat more toxic and was most effective when sprayed on and allowed to run into the crowns. Diesel oil painted on the outside of the crowns was very ineffective. It apparently penetrates living plant tissue very slowly. Applied as a spray and allowed to run down all the leaves, it eventually permeated the whole crown and killed the tissues completely.

Judging from these considerations, one must, in preparing an effective herbicidal oil, balance the factors of toxicity, viscosity, surface and interfacial tension, and volatility in order to accomplish a given task.

Suitability of Commercial Fractions to Weed Control. The natural fraction used for Diesel fuel happens to fit many of the requirements for a general contact herbicide. If, in order to improve its preignition properties and lessen smoking, one reduces the aromatic and olefinic content, this refining will lower its value as a herbicide. Another fraction-stove oil- has proved valuable as a selective spray in vegetable crops. If its A.P.I. gravity rating drops only a few degrees, or if aromatics are extracted to reduce smokiness in burning, this fraction will no longer fit requirements for killing weeds.

In most oils used for weed control, the components responsible for acute toxicity constitute a relatively small portion of the total volume; the remaining components-aliphatic hydrocarbons-are comparatively low in toxicity and act principally as carriers. In future work on the compounding of herbicidal oils, a higher degree of control may well be exercised to produce special mixtures adapted to weeds and crops. Conceivably, workers may balance the toxicity resulting from olefinic and aromatic content against the volume as related to convenience in application. In addition, they may regulate the spreading and penetrating properties by control of viscosity and surface tension. By such methods, perhaps, they will be able to produce new and better herbicides for both selective and general weed control.

\section{PROPERTIES OF EMULSIONS}

Since the unsaturated compounds in an oil fraction are largely responsible for the toxicity, apparently the bulk of most oils is relatively inert as regards injury to the plant and therefore acts principally as a carrier. If, therefore, an oil fraction carries more toxicity than is required to destroy the weed growth that it will conveniently cover, it might be extended, and its toxicity more efficiently utilized, by emulsification with water.

In the early trials with Diesel oil for roadside weed control, many attempts were made to improve the spread and cover by adding water and emulsifiers so that more volume would be available at little additional cost. Practically all such attempts failed. In view of the experiments just described, the reason seems clear. Two faults may be found with the use of Diesel-oil emulsions. First, the oil has little excess toxicity; when efficiently sprayed upon weeds it carries just about enough toxicity to kill the vegetation it will cover. Second, no emulsion of oil and water has the affinity for plant surfaces that straight oil has ; if more than a covering film is applied, the emulsion collects in droplets and runs off, and any oil included in such droplets is lost. 
Uses of Emulsions. At the outset of the experimental program on oils, it seemed that there might be several possible uses for emulsions. First, if the selective toxicant responsible for the differential killing of weeds in carrot crops could be separated, it might be applied as an emulsion in water, and thus the cost of the oil carrier would be saved. Second, a highly toxic oil such as Avon Weed Killer might be extended to make more efficient use of its toxicity. Third, with the discovery of the high toxicity of such organic compounds as dinitro-o-cresol, dinitro-sec-butylphenol, dinitro-sec-amylphenol, and pentachlorophenol, all of which are oil-soluble, it seemed possible that emulsions carrying these toxicants in solution in the oil phase might prove effective contact herbicides. Experiments to test these propositions have been conducted.

TABLE 56

Toxicity of Stove-Oil Emulsions* of Varying Composition to Carrots, Broad-Leaved WeEds, aNd Grasses; January 30, 1943

\begin{tabular}{|c|c|c|c|c|c|c|c|c|c|}
\hline \multirow{3}{*}{$\begin{array}{l}\text { Amounts of stove oil } \\
\text { and water } \\
\text { in the emulsion }\end{array}$} & \multicolumn{9}{|c|}{ Injury to carrots $(\mathrm{C})$, broad-leaved weeds (BW), and grasses $(\mathrm{G})$, in per cent } \\
\hline & \multicolumn{3}{|c|}{1 day } & \multicolumn{3}{|c|}{3 days } & \multicolumn{3}{|c|}{6 days } \\
\hline & $\mathrm{C}$ & BW & G & C & BW & G & $\mathbf{C}$ & BW & G \\
\hline $1 \mathrm{ml} \mathrm{SO}, 5 \mathrm{ml} \mathrm{W.....}$ & 0 & 20 & 20 & 0 & 20 & 20 & $\mathbf{0}$ & 20 & 20 \\
\hline $2 \mathrm{ml} \mathrm{SO}, 4 \mathrm{ml} \mathrm{W.......}$ & 0 & 60 & 50 & 0 & 60 & 50 & $\mathbf{0}$ & 75 & 50 \\
\hline $3 \mathrm{ml} \mathrm{SO}, 3 \mathrm{ml} \mathrm{W} . . . .$. & 0 & 90 & 90 & $\mathbf{0}$ & 90 & 90 & 0 & 95 & 90 \\
\hline $4 \mathrm{ml} \mathrm{SO}, 2 \mathrm{ml} \mathrm{W} . . . \ldots \ldots$ & 10 & 100 & 100 & 10 & 100 & 100 & $\mathbf{5}$ & 95 & 95 \\
\hline $5 \mathrm{ml} \mathrm{so}, 1 \mathrm{ml} \mathrm{W} \ldots \ldots \ldots \ldots \ldots \ldots$ & 50 & 100 & 100 & 40 & 100 & 100 & 40 & 95 & 100 \\
\hline $6 \mathrm{ml} \mathrm{so}, 0 \mathrm{ml} \mathrm{W} \ldots \ldots \ldots \ldots \ldots \ldots$ & 0 & 100 & 75 & 0 & 100 & 100 & 0 & 95 & 100 \\
\hline
\end{tabular}

* Emulsions were stabilized with sodium lauryl sulfate.

Tests of Emulsions. The first test involved some stove-oil emulsions stabilized with sodium lauryl sulfate and sprayed on carrots. Table 56 presents the results. Sodium lauryl sulfate was present in the water at a concentration of $1 / 10$ per cent by weight.

If the data of this table are compared with those of table 3 , it will be found that the emulsions were somewhat more toxic than equivalent volumes of straight oil. In either case, however, 4 to $5 \mathrm{ml}$ of oil was required to kill the weeds, and emulsions containing these amounts of oil were more toxic to carrots than were the straight oil sprays.

The next experiment tested emulsions of Avon Weed Killer and Diesel oil. Both unstabilized and stabilized emulsions of the weed killer were used. The results (table 57) show that this highly aromatic fraction (Avon Weed Killer) is selective if diluted with odorless kerosene. It is also selective when used as an emulsion in water. The emulsion stabilized by adding $1 / 1.0$ per cent of Vatsol (OT 70 per cent clear) by weight to the water was somewhat more toxic to both weeds and carrots than was the unstabilized mixture. Although the 50:50 Diesel oil and water mixture was selective, injury developed slowly and was not nearly complete on broad-leaved weeds.

Fmulsions on Flax. Carrying the same idea further, an extensive experiment was conducted with gasoline, stove oil, Diesel oil, and Avon Weed Killer 
used in dilutions with odorless kerosene and as emulsions both stabilized and unstabilized. The test plants were flax, mustard, and barley. The cultures were young, and the plants succulent and rapidly growing. Selectivity was poor throughout, and no mixture looked good enough to offer commercial possibilities. The only generalization derived from the experiment was that the use of oils, as emulsions, on young tender flax is a hazardous procedure.

TABLE 57

Toxicity of Avon Weed Killer and Diesel Oil at Various Concentrations to Carrots, Broad-leaved Weeds, and Grass ; February 22, 1944

\begin{tabular}{|c|c|c|c|c|c|c|c|c|c|c|c|c|}
\hline \multirow{3}{*}{$\begin{array}{l}\text { Oil fraction and amounts } \\
\text { of fraction and diluent } \\
\text { applied per culture }\end{array}$} & \multicolumn{12}{|c|}{ Injury to carrots $(C)$, broad-leaved weeds (BW), and grass (G), in per cent } \\
\hline & \multicolumn{3}{|c|}{$1 \mathrm{day}$} & \multicolumn{3}{|c|}{3 days } & \multicolumn{3}{|c|}{8 days } & \multicolumn{3}{|c|}{16 days } \\
\hline & $\mathrm{C}$ & Biw & G & $\mathbf{C}$ & BW & G & C & BW & G & C & BW & G \\
\hline \multicolumn{13}{|l|}{$\begin{array}{l}\text { Avon Weed Killer and } \\
\text { odorless kerosene: }\end{array}$} \\
\hline $5 \mathrm{ml} \mathrm{F,} 5 \mathrm{ml} \mathrm{OK} \ldots \ldots \ldots$ & 25 & 100 & 95 & 40 & 100 & 100 & 40 & 100 & 100 & 20 & 100 & 100 \\
\hline $21 / 2 \mathrm{ml} \mathrm{F}, 71 / 2 \mathrm{ml} \mathrm{OK} \ldots$ & 0 & 100 & 90 & 5 & 100 & 100 & $\mathbf{5}$ & 100 & 100 & 5 & 100 & 100 \\
\hline $11 / 4 \mathrm{ml} \mathrm{F}, 83 / 4 \mathrm{ml} \mathrm{OK}$. & 0 & 75 & 60 & 0 & 70 & 75 & 0 & 80 & 100 & 0 & 75 & 100 \\
\hline $8 / 8 \mathrm{ml} \mathrm{F}, 98 / 8 \mathrm{ml} \mathrm{OK} . \ldots \ldots \ldots$ & 0 & 20 & 5 & 0 & 20 & 10 & 0 & 25 & 20 & 0 & 20 & 50 \\
\hline $\begin{array}{l}\text { Avon Weed Killer and water } \\
\text { emulsion: }\end{array}$ & & & & & & & & & & & & \\
\hline $21 / 2 \mathrm{ml} \mathrm{F}, 71 / 2 \mathrm{ml} \mathrm{W} \ldots \ldots$ & 0 & 75 & 75 & 10 & 95 & 90 & 10 & 95 & 75 & 5 & 75 & 75 \\
\hline $11 / 4 \mathrm{ml} \mathrm{F}, 88 / 4 \mathrm{ml} \mathrm{W} \ldots$. & 0 & 60 & 50 & $\mathbf{0}$ & 90 & 60 & 0 & 75 & 60 & 0 & 60 & 60 \\
\hline $8 / 8 \mathrm{ml} \mathrm{F}, 98 / 8 \mathrm{ml} \mathrm{W} \ldots \ldots \ldots \ldots$ & 0 & 25 & 30 & $\mathbf{0}$ & 40 & 50 & 0 & 50 & 50 & 0 & 30 & 90 \\
\hline $\begin{array}{l}\text { Avon Weed Killer and Vatsol } \\
\text { solution:* }\end{array}$ & & & & & & & & & & & & \\
\hline $21 / 2 \mathrm{ml} \mathrm{F}, 71 / 2 \mathrm{ml} \mathrm{V} \ldots \ldots \ldots \ldots$ & 20 & 90 & 90 & 25 & 100 & 90 & 25 & 100 & 90 & 15 & 100 & 95 \\
\hline $11 / 4 \mathrm{ml} \mathrm{F}, 88 / 4 \mathrm{ml} \mathrm{V} \ldots \ldots \ldots \ldots$ & 0 & 75 & 90 & $\mathbf{5}$ & 95 & 90 & $\mathbf{5}$ & 100 & 75 & 5 & 100 & 80 \\
\hline $8 / 8 \mathrm{ml} \mathrm{F}, 98 / 8 \mathrm{ml} \mathrm{V} \ldots \ldots \ldots \ldots$ & 0 & 60 & 60 & 0 & 50 & 75 & 0 & 50 & 70 & 0 & 50 & 75 \\
\hline \multicolumn{13}{|l|}{ Diesel oil and water emulsion: } \\
\hline $5 \mathrm{ml} \mathrm{F}, 5 \mathrm{ml} \mathrm{W} \ldots \ldots \ldots \ldots \ldots$ & 0 & 30 & 50 & 5 & 40 & 75 & 5 & 50 & 90 & 5 & 50 & 100 \\
\hline $21 / 2 \mathrm{ml} \mathrm{F}, 71 / 2 \mathrm{ml} \mathrm{W} \ldots \ldots \ldots \ldots$ & 0 & 15 & 20 & 0 & 20 & 50 & 0 & 25 & 50 & 0 & 25 & 70 \\
\hline $11 / 4 \mathrm{ml} \mathrm{F}, 88 / 4 \mathrm{ml} \mathrm{W} \ldots \ldots \ldots \ldots$ & 0 & 10 & 5 & 0 & 10 & 10 & 0 & 10 & 25 & 0 & 10 & 90 \\
\hline
\end{tabular}

* Vatsol solution: Vatsol OT 70 per cent clear was used at a concentration of $1 / 10$ per cent by volume.

Emulsions on Onions. Since a selective kill of grass and weeds in onions seemed possible (see tables $50,51,52$, and 53 ), a series of dilutions and emulsions of xylene, TS-28 solvent, Edeleanu extract, and gasoline was tested on onions, grass, and broad-leaved weeds. Table 58 presents the results.

The emulsions used in this experiment were highly toxic to grasses, somewhat less toxic to broad-leaved weeds, and less toxic to onions. Xylene and white gasoline were selective enough to look promising; the highly aromatic TS-28 and the Edeleanu extract were too toxic, even at the lowest concentrations used, to be commercially feasible. It was apparent during this experiment that all the emulsions killed faster than did the straight oil mixtures. Since, however, they did not penetrate so well, grasses tended to recover toward the end of the experiment. The emulsions never showed higher selectivity than the oil mixtures.

In the use of emulsions the phase relations are important. When the water makes up the external phase, the emulsion presumably will react on the plant like an aqueous spray; when oil constitutes the external phase, the spray 
should spread like an oil. The producers of Avon Weed Killer submitted two samples for testing - one of the usual type and one containing reagents that caused it to form the water-in-oil or invert type of emulsion. Emulsions of

\section{TABLE 58}

Toxicity of Aromatic Fractions to Onions, Grass, and Broad-Leaved Weeds; APRIL 14, 1944

\begin{tabular}{|c|c|c|c|c|c|c|c|c|c|c|c|c|c|c|c|}
\hline \multirow{3}{*}{$\begin{array}{l}\text { Oil fraction and amounts of fraction and } \\
\text { diluent applied per culture }\end{array}$} & \multicolumn{15}{|c|}{$\begin{array}{l}\text { Injury to onions }(\mathrm{O}), \text { grass }(\mathrm{G}) \text {, and broad-leaved weeds (BW), } \\
\text { in per cent }\end{array}$} \\
\hline & \multicolumn{3}{|c|}{1 day } & \multicolumn{3}{|c|}{3 days } & \multicolumn{3}{|c|}{5 days } & \multicolumn{3}{|c|}{10 days } & \multicolumn{3}{|c|}{15 days } \\
\hline & $\mathbf{O}$ & G & BW & 0 & G & BW & 0 & G & BW & $\mathbf{O}$ & G & BW & $\mathbf{O}$ & G & BW \\
\hline \multicolumn{16}{|l|}{ Xylene and odorless kerosene: } \\
\hline $5 \mathrm{ml} \mathrm{F}, 5 \mathrm{ml} \mathrm{OK} \ldots \ldots \ldots \ldots$ & 10 & 75 & 50 & 10 & 90 & 50 & 10 & 95 & 50 & $\mathbf{5}$ & 100 & 50 & 5 & 100 & 50 \\
\hline $4 \mathrm{ml}$ & 10 & 75 & 30 & 10 & 90 & 50 & 10 & 95 & 50 & 5 & 100 & 75 & 5 & 100. & 100 \\
\hline $3 \mathrm{ml} \mathrm{F}, 7 \mathrm{ml} \mathrm{OK} \ldots \ldots \ldots \ldots$ & 0 & 40 & 25 & 0 & 60 & 20 & 0 & 75 & 20 & 0 & 85 & 10 & 0 & 95 & 25 \\
\hline \multicolumn{16}{|l|}{ Xylene and Vatsol solution*: } \\
\hline $5 \mathrm{ml} \mathrm{F,} 5 \mathrm{ml} \mathrm{V} \ldots \ldots \ldots \ldots$ & 30 & 90 & 80 & 30 & 90 & 80 & 20 & 95 & 80 & 5 & 100 & 80 & 5 & 100 & 80 \\
\hline $4 n$ & 20 & 60 & 70 & 20 & 60 & 70 & 10 & 50 & 70 & 5 & 50 & 70 & 0 & 50 & 70 \\
\hline $3 \mathrm{ml} \mathrm{F}, 7 \mathrm{ml} \mathrm{V} \ldots \ldots \ldots \ldots \ldots \ldots$ & 15 & 50 & 30 & 15 & 70 & 30 & 20 & 50 & 50 & 5 & 50 & 50 & 5 & 75 & 70 \\
\hline \multicolumn{16}{|l|}{ TS-28 solvent and odorless kerosene: } \\
\hline $5 \mathrm{ml} \mathrm{F}, 5 \mathrm{ml} \mathrm{OK} \ldots \ldots \ldots \ldots \ldots \ldots$ & 50 & 95 & 90 & 50 & 95 & 95 & 60 & 100 & 95 & 40 & 100 & 100 & 40 & 100 & 100 \\
\hline $4 \mathrm{ml} \mathrm{F}, 6 \mathrm{ml} \mathrm{O}$ & 30 & 50 & 20 & 30 & 90 & 50 & 30 & 100 & 50 & 15 & 100 & 50 & 20 & 100 & 50 \\
\hline $3 \mathrm{ml} \mathrm{F}, 7 \mathrm{ml} \mathrm{OK} \ldots \ldots \ldots \ldots \ldots \ldots$ & 25 & 50 & 40 & 15 & 70 & 40 & 10 & 90 & 40 & $\mathbf{5}$ & 100 & 40 & 20 & 100 & 50 \\
\hline \multicolumn{16}{|l|}{ TS-28 solvent and Vatsol solution*: } \\
\hline $5 \mathrm{ml} \mathrm{F}, 5 \mathrm{ml} \mathrm{V} \ldots \ldots \ldots \ldots \ldots \ldots$ & 60 & 90 & 90 & 50 & 95 & 90 & 40 & 80 & 95 & 20 & 70 & 100 & 30 & 80 & 100 \\
\hline $4 \mathrm{ml}$ & 40 & 90 & 95 & 40 & 90 & 95 & 30 & 70 & 90 & 15 & 50 & 95 & 30 & 50 & 100 \\
\hline $3 \mathrm{ml} \mathrm{F}, 7 \mathrm{ml} \mathrm{V} \ldots \ldots \ldots \ldots \ldots \ldots \ldots$ & 40 & 80 & 90 & 30 & 75 & 90 & 30 & 60 & 90 & 15 & 50 & 100 & 20 & 50 & 100 \\
\hline \multirow{2}{*}{\multicolumn{16}{|c|}{$\begin{array}{l}\text { Edeleanu extract (E-1295) and odorless } \\
\text { kerosene: }\end{array}$}} \\
\hline & & & & & & & & & & & & & & & \\
\hline $5 \mathrm{ml} \mathrm{F}, 5 \mathrm{ml} \mathrm{OK} \ldots \ldots \ldots \ldots \ldots \ldots$ & 50 & 90 & 80 & 50 & 90 & 80 & 60 & 100 & 100 & 75 & 100 & 100 & 75 & 100 & 100 \\
\hline $4 n$ & 50 & 90 & 95 & 50 & 95 & 95 & 50 & 100 & 100 & 60 & 100 & 100 & 60 & 100 & 100 \\
\hline $3 \mathrm{ml} \mathrm{F}, 7 \mathrm{ml} \mathrm{OK} \ldots \ldots \ldots \ldots$ & 40 & 95 & 90 & 40 & 95 & 95 & 75 & 100 & 100 & 90 & 100 & 100 & 100 & 100 & 100 \\
\hline \multicolumn{16}{|l|}{$\begin{array}{l}\text { Edeleanu extract (E-1295) and Vatsol } \\
\text { solution*: }\end{array}$} \\
\hline $5 \mathrm{ml} \mathrm{F}, 5 \mathrm{ml} \mathrm{V} \ldots \ldots \ldots \ldots \ldots \ldots$ & 60 & 95 & 95 & 75 & 95 & 95 & 75 & 90 & 100 & 75 & 100 & 100 & 75 & 100 & 100 \\
\hline & 60 & 95 & 95 & 75 & 95 & 95 & 60 & 90 & 100 & 60 & 80 & 100 & 60 & 90 & 100 \\
\hline $3 \mathrm{ml} \mathrm{F}, 7 \mathrm{ml} \mathrm{V} \ldots \ldots \ldots \ldots \ldots \ldots \ldots$ & 75 & 95 & 95 & 90 & 95 & 95 & 95 & 100 & 100 & 90 & 100 & 100 & 90 & 100 & 100 \\
\hline \multicolumn{16}{|l|}{ White gasoline and odorless kerosene: } \\
\hline $10 \mathrm{ml} \mathrm{F,} 0 \mathrm{ml} \mathrm{OK} \ldots \ldots \ldots \ldots \ldots \ldots$ & 50 & 95 & 75 & 40 & 90 & 60 & 30 & 90 & 40 & 15 & 90 & 30 & 20 & 90 & 40 \\
\hline $71 / 2 \mathrm{ml} \mathrm{F}, 21 / 2 \mathrm{ml} \mathrm{OK}$ & $\mathbf{5}$ & 95 & 75 & 5 & 95 & 75 & $\mathbf{5}$ & 100 & 50 & $\mathbf{0}$ & 100 & 50 & 0 & 100 & 80 \\
\hline $5 \mathrm{ml} \mathrm{F}, 5 \mathrm{ml} \mathrm{OK} \ldots \ldots \ldots \ldots \ldots \ldots$ & 0 & 0 & 20 & 0 & $\mathbf{0}$ & 15 & 0 & 50 & 20 & 0 & 75 & 20 & 0 & 50 & 20 \\
\hline \multicolumn{16}{|l|}{ White gasoline and Vatsol solution*: } \\
\hline $71 / 2 \mathrm{ml} \mathrm{F}, 21 / 2 \mathrm{ml} \mathrm{V} \ldots \ldots \ldots \ldots \ldots$ & 50 & 90 & 95 & 50 & 95 & 95 & 40 & 50 & 95 & 40 & 50 & 100 & 30 & 70 & 100 \\
\hline $5 \mathrm{ml} \mathrm{F}, 5 \mathrm{ml} \mathrm{V} \ldots$ & 30 & 75 & 90 & 40 & 70 & 95 & 30 & 30 & 95 & 20 & 30 & 100 & 10 & 30 & 100 \\
\hline
\end{tabular}

- Vatsol OT 70 per cent clear was used at a concentration of $1 / 10$ per cent by volume.

both types were prepared at varying proportions of oil to water and applied to plants. Total volume was the same in all cases and did not provide excess solution for runoff.

Since, under these conditions, toxicities of the two types proved identical, apparently one can gain no advantage by making an invert emulsion where spray volume is controlled so that no runoff occurs. Emulsion of the invert type, however, did spread somewhat more rapidly than the oil-in-water type.

Use of Sulfur in Diesel-Oil Emulsions. During the experiments described above, a report was received from Ethelbert Johnson, District Supervisor of 
TABLE 59

Toxicity of Diesel Oil and Diesel-Oil Emulsions with and without Sulfur to Barley ANd Mustard; JanUary 30, 1945

\begin{tabular}{|c|c|c|c|c|c|c|c|c|}
\hline \multirow{3}{*}{$\begin{array}{l}\text { Mixture, culture, and amount } \\
\text { applied per culture }\end{array}$} & \multicolumn{8}{|c|}{ Injury to barley (B) and mustard (M), in per cent } \\
\hline & \multicolumn{2}{|c|}{1 day } & \multicolumn{2}{|c|}{3 days } & \multicolumn{2}{|c|}{6 days } & \multicolumn{2}{|c|}{10 days } \\
\hline & B & $\mathbf{M}$ & B & $\mathbf{M}$ & B & M & B & M \\
\hline \multicolumn{9}{|l|}{$\begin{array}{l}\text { Diesel oil and water, } 50: 50: \\
\text { Young barley and mustard: }\end{array}$} \\
\hline $3 \mathrm{ml} . \ldots \ldots \ldots \ldots \ldots \ldots \ldots \ldots \ldots \ldots \ldots \ldots$ & 0 & 5 & 0 & 10 & 10 & 20 & 10 & 20 \\
\hline $4 \mathrm{ml} . \ldots \ldots \ldots \ldots \ldots \ldots$ & 0 & $\mathbf{5}$ & 5 & 50 & 25 & 75 & 75 & 60 \\
\hline $6 \mathrm{ml} \ldots \ldots \ldots \ldots \ldots \ldots \ldots$ & 0 & 20 & 25 & 75 & 60 & 95 & 100 & 95 \\
\hline $9 \mathrm{ml} \ldots \ldots \ldots$ & 10 & 40 & 50 & 85 & 90 & 100 & 100 & 95 \\
\hline $12 \mathrm{ml} \ldots \ldots$. & 20 & 50 & 75 & 90 & 95 & 100 & 100 & 100 \\
\hline \multicolumn{9}{|l|}{ Tall barley: } \\
\hline $6 \mathrm{ml} . . . . .$. & 0 & .. & 5 & .. & 20 & .. & 50 & .. \\
\hline $9 \mathrm{ml} \ldots .$. & 0 & .. & 10 & .. & 40 & .. & 75 & .. \\
\hline $12 \mathrm{ml} \ldots \ldots \ldots$ & 0 & .. & 20 & .. & 70 & .. & 90 & .. \\
\hline \multicolumn{9}{|l|}{ Tall mustard: } \\
\hline $9 \mathrm{ml} \ldots \ldots \ldots$ & .. & 15 & .. & 25 & .. & 30 & .. & 40 \\
\hline $18 \mathrm{ml} \ldots \ldots \ldots \ldots \ldots \ldots \ldots \ldots \ldots$ & .. & 25 & .. & 75 & .. & 75 & .. & 75 \\
\hline \multirow{2}{*}{\multicolumn{9}{|c|}{$\begin{array}{l}\text { Diesel oil and water, } 50: 50 \text { plus sulfur: } \\
\text { Young barley and mustard: }\end{array}$}} \\
\hline Young barley and mustard: & & & & & & & & \\
\hline $3 \mathrm{ml} \ldots \ldots \ldots \ldots \ldots \ldots \ldots$ & 0 & 20 & 25 & 75 & 75 & 90 & 95 & 100 \\
\hline $4 \mathrm{ml} \ldots \ldots \ldots \ldots \ldots \ldots \ldots$ & $\mathbf{5}$ & 25 & 75 & 75 & 90 & 90 & 100 & 90 \\
\hline $6 \mathrm{ml} \ldots \ldots \ldots$ & 10 & 75 & 90 & 85 & 95 & 100 & 100 & 100 \\
\hline $9 \mathrm{ml} .$. & 40 & 90 & 95 & 100 & 100 & 100 & 100 & 100 \\
\hline $12 \mathrm{ml} . \ldots .$. & 60 & 90 & 100 & 100 & 100 & 100 & 100 & 100 \\
\hline \multicolumn{9}{|l|}{ Tall barley: } \\
\hline $6 \mathrm{ml} \ldots \ldots$ & $\mathbf{0}$ & .. & 25 & .. & 40 & .. & 50 & .. \\
\hline $9 \mathrm{ml} \ldots \ldots$ & 5 & .. & 40 & .. & 75 & .. & 95 & .. \\
\hline $12 \mathrm{ml} \ldots \ldots \ldots$ & 10 & .. & 60 & .. & 95 & .. & 100 & .. \\
\hline \multicolumn{9}{|l|}{ Tall mustard: } \\
\hline $9 \mathrm{ml} . \ldots \ldots \ldots$ & .. & 40 & .. & 80 & .. & 80 & .. & 80 \\
\hline $18 \mathrm{ml}, \ldots \ldots \ldots \ldots$ & .. & 65 & .. & 95 & .. & 95 & .. & 95 \\
\hline \multicolumn{9}{|l|}{ Diesel oil straight: } \\
\hline \multicolumn{9}{|l|}{ Young barley and mustard: } \\
\hline $11 / 2 \mathrm{ml} \ldots \ldots \ldots \ldots \ldots$ & 5 & 10 & 25 & 50 & 60 & 75 & 90 & 75 \\
\hline $2 \mathrm{ml} . \ldots \ldots \ldots$ & $\mathbf{5}$ & 20 & 50 & 50 & 75 & 75 & 90 & 75 \\
\hline $3 \mathrm{ml} . \ldots \ldots$ & 15 & 75 & 75 & 100 & 95 & 100 & 100 & 100 \\
\hline $41 / 2 \mathrm{ml} \ldots .$. & 20 & 75 & 90 & 100 & 100 & 100 & 100 & 100 \\
\hline & 60 & 90 & 95 & 100 & 100 & 100 & 100 & 100 \\
\hline \multicolumn{9}{|l|}{ Tall barley: } \\
\hline $3 \mathrm{ml} . \ldots \ldots$ & 0 & .. & 20 & .. & 60 & .. & 60 & .. \\
\hline $41 / 2 \mathrm{ml} \ldots \ldots$ & $\mathbf{5}$ & .. & 40 & .. & 75 & .. & 95 & .. \\
\hline & 10 & .. & 60 & .. & 75 & .. & 80 & .. \\
\hline \multicolumn{9}{|l|}{ Tall mustard: } \\
\hline $41 / 2 \mathrm{ml} \ldots \ldots \ldots \ldots \ldots \ldots$ & .. & 25 & .. & 75 & .. & 80 & .. & 80 \\
\hline $9 \mathrm{ml} \ldots \ldots \ldots \ldots \ldots \ldots$ & .. & 40 & .. & 95 & .. & 95 & .. & 95 \\
\hline
\end{tabular}

Weed and Rodent Control, State of California : spray operators in his territory were using 50:50 emulsions of Diesel oil and water containing 0.6 per cent sulfur, with results comparable with those secured with pure Diesel oil. An experiment to test this question was designed; the results appear in table 59. Sulfur was included in the second emulsion at a rate of 2 grams in $332 \mathrm{ml}$ of the $50: 50$ mixture. No stabilizer was used. 
From table 59 it is apparent that the emulsion plus sulfur was more toxic than the one without; in fact, it was equal to the straight Diesel oil, which indicates that the 2 grams of sulfur added as much killing power to the mixture as $166 \mathrm{ml}$ of oil would have done.

In further correspondence Mr. Johnson mentioned that the addition of 2 or 3 gallons of high-asphalt fuel oil per 100 gallons will change a 50:50 emulsion of Diesel oil and water from an oil-in-water to a water-in-oil type-in other words, will bring about inversion. Adding 5 pounds of dusting sulfur to 100 gallons of the same mixture had a similar effect. Mr. Johnson concluded that inversion caused the increase in toxicity; hence the effect was physical rather than chemical. In the experiment described, however, there was a decided difference between the action of the mixture containing sulfur and the others. This mixture proved more toxic to the young cultures than an equivalent volume of oil. The series with sulfur resembled that with straight oil for about 6 days; then the plants sprayed with the sulfur mixture started to turn light in color; and by the end of the observation period they were almost completely bleached. Evidently the sulfur had oxidized and produced the characteristic chemical action of $\mathrm{SO}_{2}$. This result justifies further study, since it indicates a method for materially lowering the cost of using Diesel oil as a contact herbicide.

\section{FORTIFIED OILS AND OIL EMULSIONS}

As explained in the foregoing sections, the naturally occurring toxicants in oil fractions are not highly toxic. To kill weeds, the concentration of acute toxicants must be in the order of 20 per cent or more; chronic toxicants, though more effective, act slowly. In spite of the expense involved, the use of acute toxicants in the boiling range of third-structure gasoline, kerosene, and stove oil as selective weed killers in vegetable crops seems justified. Unfortunately, however, these toxicants are too costly to serve as general contact herbicides.

Slow Action of Heavy Oils. The heavier oils are much less spectacular in their effects. Even though they kill, the action takes many days; and in some situations this is a real disadvantage-for instance in preparing firebreaks on highways, where vegetation must be killed rapidly in preparation for burning, before the surrounding plants become dry enough to carry fire. The refining of Diesel and similar fuel oils tends to lower acute toxicity and to make their killing action even slower.

Oil-tolerant Weed Species. A further drawback to the use of oils as general contact herbicides is the fact that weeds of the family Umbelliferae are oil-tolerant and many other species are not readily killed. Fennel and star thistle have invaded the firestrips along California highways; in some places they have become as serious a hazard as the original vegetation.

Fortification of Oils. The nitro- and chlorophenols are highly effective acute toxicants. Dinitro-o-cresol, dinitro-sec-butylphenol, dinitro-sec-amylphenol, and pentachlorophenol are all valuable fortifying agents for increasing the speed and thoroughness of killing by oil sprays. Furthermore, if one makes a concentrated solution of one of these toxicants in oil, the killing potential is so high that it greatly exceeds the covering ability of the liquid; hence the solution can be effectively extended by emulsification. 
In general, polar compounds are more soluble in polar solvents, nonpolar compounds in nonpolar solvents; and the more the solute resembles the solvents in chemical properties, the greater the solubility. Hence the solution of the substituted phenols in oils depends upon two factors: (1) the content of polar compounds (mainly olefinic and aromatic) in the oil ; 2 ) the type and degree of substitution in the phenyl ring of the phenol compound.

It was found that dinitrocresol dissolves to the extent of about $1 / 2$ per cent in kerosene, a highly aliphatic solvent; dissolves to about 1 per cent in stove oil containing around 20 per cent unsaturates; is over 10 per cent soluble in xylene, an aromatic hydrocarbon. Pentachlorophenol is 8 per cent soluble in Diesel oil; about 16 per cent in Avon Weed Killer.

TABLE 60

Toxicity of Emulsions of Stove Oil in Water Containing Sodium PentachloroPhenate to Barley and Annual Bluegrass ; January 24, 1944

\begin{tabular}{|c|c|c|c|c|c|c|c|c|c|c|}
\hline \multirow{3}{*}{$\begin{array}{l}\text { Amount of stove oil (SO) applied } \\
\text { per culture with } 10 \mathrm{ml} \text { stock solution, } \\
\text { and total volume applied }\end{array}$} & \multicolumn{10}{|c|}{ Total injury to barley (B) and annual bluegrass (BG), in per cent } \\
\hline & \multicolumn{2}{|c|}{1 day } & \multicolumn{2}{|c|}{2 days } & \multicolumn{2}{|c|}{3 days } & \multicolumn{2}{|c|}{11 days } & \multicolumn{2}{|c|}{14 days } \\
\hline & B & BG & B & BG & B & BG & B & BG & B & BG \\
\hline $0.025 \mathrm{ml} \mathrm{SO}$, total $10.025 \mathrm{ml}$. & 0 & $\mathbf{5}$ & 0 & 40 & 0 & 60 & 0 & 90 & 0 & 100 \\
\hline $0.050 \mathrm{ml} \mathrm{SO}$, total $10.05 \mathrm{ml}$. . & 0 & 10 & $\mathbf{5}$ & 35 & 5 & 60 & 5 & 75 & 5 & 100 \\
\hline $0.1 \mathrm{ml} \mathrm{sO}$, total $10.1 \mathrm{ml} \ldots$ & $\mathbf{5}$ & 20 & 10 & 60 & 10 & 75 & 10 & 100 & 10 & 100 \\
\hline $0.2 \mathrm{ml} \mathrm{SO}$, total $10.2 \mathrm{ml} \ldots$ & 10 & 25 & 20 & 75 & 15 & 85 & 10 & 100 & 10 & 100 \\
\hline $0.3 \mathrm{ml} \mathrm{sO}$, total $10.3 \mathrm{ml} \ldots$ & 15 & 30 & 25 & 70 & 25 & 85 & 10 & 100 & 10 & 100 \\
\hline $0.4 \mathrm{ml} \mathrm{sO}$, total $10.4 \mathrm{ml} \ldots$ & 15 & 30 & 25 & 70 & 25 & 90 & 10 & 100 & 10 & 100 \\
\hline $0.5 \mathrm{ml} \mathrm{SO}$, total $10.5 \mathrm{ml} \ldots$ & 20 & 50 & 40 & 80 & 40 & 90 & 15 & 100 & 15 & 100 \\
\hline $0.6 \mathrm{ml} \mathrm{SO}$, total $10.6 \mathrm{ml} \ldots \ldots$ & 30 & 60 & 60 & 90 & 50 & 95 & 30 & 100 & 25 & 100 \\
\hline $0.8 \mathrm{ml} \mathrm{sO}$, total $10.8 \mathrm{ml} \ldots \ldots \ldots \ldots \ldots \ldots$ & 50 & 70 & 60 & 90 & 60 & 95 & 40 & 100 & 40 & 100 \\
\hline $1.0 \mathrm{ml} \mathrm{sO}$, total $11.0 \mathrm{ml} \ldots \ldots \ldots \ldots \ldots \ldots$ & 75 & 80 & 75 & 90 & 50 & 95 & 40 & 100 & 40 & 100 \\
\hline
\end{tabular}

* This stock solution contained 1 per cent sodium pentachlorophenate, $1 / 4$ per cent aluminum sulfate, and $1 / 10$ per cent Vatsol (OT 70 per cent clear) by weight.

Considering the solubility of substituted phenols in oils, the longer the chain substitution of a dinitro-substituted phenol, the greater the solubility of the compound in oil. Dinitro phenol is only slightly soluble in Diesel oil, dinitrocresol is soluble to about 1 per cent, and dinitro-sec-butylphenol to around 20 per cent; the amyl compound is an oily liquid miscible in all proportions at room temperature. If suitable emulsifiers are added, the dinitro-sec-amylphenol will make a ready-mix type of emulsion of high stability in water without the addition of oil.

Tests of Fortified-Oil Emulsions. Many experiments were performed exploring the possible combinations of toxicants, oils, and stabilizers. Table 60 presents data from one such test. In this a stock solution containing 1 per cent sodium pentachlorophenate, $1 / 4$ per cent aluminum sulfate, and $1 / 10$ per cent Vatsol (OT 70 per cent clear) by weight in water was made up. To this were added varying volumes of oil, as indicated in the table. Oil volume is in percentage by volume. The data show a consistent increase in toxicity with increasing volume of oil through the whole series. Results in the field confirm this relation. 
There was an extended series of tests on the relation between concentration of the activated sodium pentachlorophenate and toxicity at three levels of stove-oil concentration-namely 2,4 , and 8 per cent. The results showed that rather large increases in concentration of either of these essential constituents are required to bring about complete killing of grasses, as compared with results in the 80 to 95 per cent toxicity region. With 2 per cent oil an increase of pentachlorophenate concentration from $1 / 2$ per cent up to 1 per cent significantly heightened the toxicity ; further increase in concentration was useless. At 4 per cent oil, increase of phenate toxicity from $1 / 2$ per cent to $3 / 4$ per cent was effective; further increase was useless. At 8 per cent oil, toxicity was con-

TABLE 61

Toxicity of Stove Oil and Emulsions of Stove Oil and Water Containing Activated Sodium Pentachlorophenate and Vatsol to Barley ; February 2, 1944

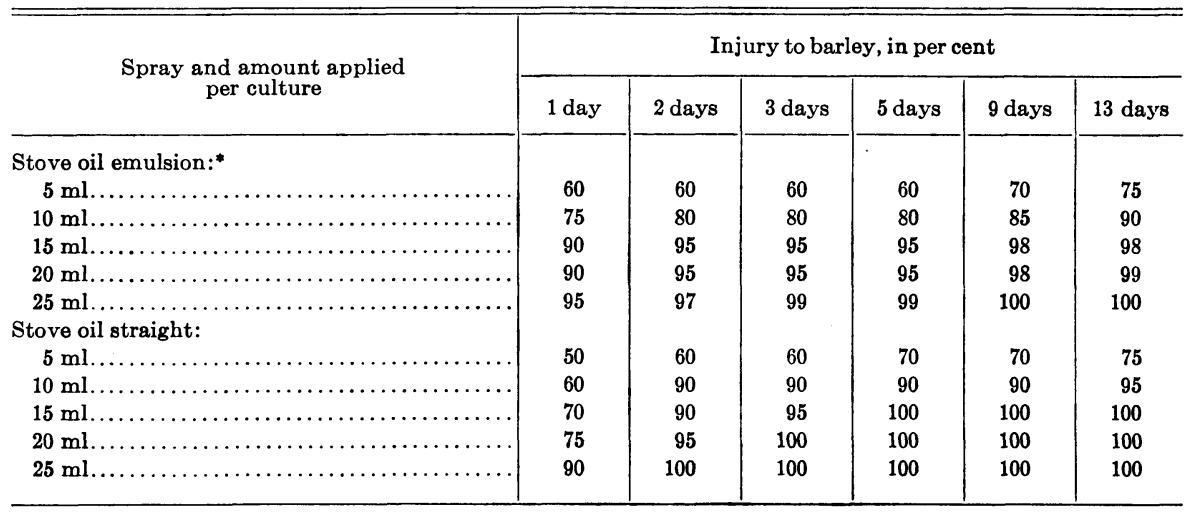

*Stove-oil emulsion, percentages in water:

Sodium pentachlorophenate.................... per cent by weight

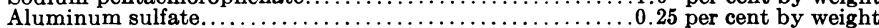

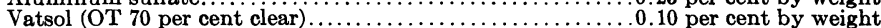

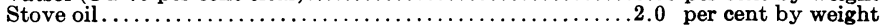

stant throughout the range $1 / 2$ to 2 per cent of phenate; and it was as high as the toxicity at higher phenate levels with less oil.

Table 61 compares this type of emulsion with straight stove oil. At the higher volume rates the emulsion compared very favorably with straight stove oil. If the oil content had been raised to 6 per cent by volume, the liquids would have been almost identical in toxicity.

In subsequent experiments, pentachlorophenol dissolved directly in the oil of an emulsion proved to be as effective as the activated sodium salt dissolved in the aqueous phase. When Avon Weed Killer was used, a solution containing $1 / 2$ per cent pentachlorophenol in 3 per cent oil with 0.1 per cent Vatsol proved highly toxic against star thistle and grass at $15 \mathrm{ml}$ per culture; in fact, this emulsion was equivalent, volume for volume, with stove oil and Diesel oil as a contact killer.

When dinitro-sec-butylphenol became available for testing, a series of experiments indicated it to be roughly four times as toxic as dinitrocresol and pentachlorophenol, somewhat more toxic than dinitro-sec-amylphenol. Being readily soluble in oil, it offered much promise as a contact herbicide. 
Quantitative Relations of Oil and Fortifying Agent. One problem in concocting a general contact herbicide from oil and a dinitro compound is to arrive at the most economical mixture of the two from the herbicidal standpoint. Tests were conducted using a mixture of oil and stabilizer with and without the dinitro compound. When these were mixed in varying propor-

TABLE 62

Toxicity of Emulsions Containing Dinitro-sec-Butylphenol and Diesel Oil, or Dow Contact Herbicide and Diesel Oil, TO GRASSES ; DeCEMBER 5, 1944

\begin{tabular}{|c|c|c|c|c|c|c|}
\hline \multirow{2}{*}{ Concentrations, in per cent* } & \multicolumn{6}{|c|}{ Injury to grasses, in per cent } \\
\hline & 1 day & 2 days & 3 days & 4 days & 6 days & 8 days \\
\hline \multicolumn{7}{|l|}{$\begin{array}{l}\text { Dinitro-sec-butylphenol and Diesel oil emulsions: } \\
0.68 \text { per cent DN: }\end{array}$} \\
\hline 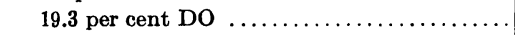 & 75 & 98 & 100 & 100 & 100 & 100 \\
\hline 9.3 per cent DO & 75 & 98 & 98 & 98 & 98 & 98 \\
\hline 4.3 per cent DO & 60 & 98 & 98 & 98 & 98 & 98 \\
\hline \multicolumn{7}{|l|}{0.34 per cent $\mathrm{DN}$ : } \\
\hline 9.6 per cent $D O \ldots \ldots \ldots \ldots \ldots \ldots \ldots \ldots$ & 60 & 95 & 100 & 100 & 100 & 100 \\
\hline 4.6 per cent $D O \ldots \ldots \ldots \ldots \ldots \ldots \ldots \ldots \ldots$ & 60 & 95 & 95 & 95 & 95 & 95 \\
\hline 2.2 per cent $\mathrm{DO} \ldots \ldots \ldots \ldots \ldots \ldots \ldots \ldots \ldots$ & 50 & 95 & 98 & 98 & 98 & 98 \\
\hline \multicolumn{7}{|l|}{0.17 per cent $\mathrm{DN}:$} \\
\hline 4.8 per cent $\mathrm{DO} \ldots \ldots \ldots \ldots \ldots \ldots \ldots \ldots \ldots$ & 40 & 90 & 90 & 90 & 90 & 90 \\
\hline 2.3 per cent $D O \ldots \ldots \ldots \ldots \ldots \ldots \ldots \ldots \ldots$ & 40 & 90 & 95 & 95 & 90 & 90 \\
\hline 1.1 per cent $D O \ldots \ldots \ldots \ldots \ldots \ldots \ldots \ldots$ & 40 & 90 & 95 & 95 & 95 & 95 \\
\hline \multicolumn{7}{|l|}{0.08 per cent $\mathrm{DN}:$} \\
\hline 2.4 per cent $\mathrm{DO} \ldots \ldots \ldots \ldots \ldots \ldots \ldots \ldots \ldots$ & 20 & 80 & 90 & 90 & 90 & 90 \\
\hline 1.2 per cent $D O \ldots \ldots \ldots \ldots \ldots \ldots \ldots \ldots \ldots$ & 20 & 75 & 90 & 90 & 90 & 90 \\
\hline 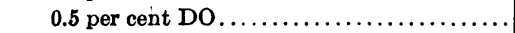 & 25 & 80 & 95 & 95 & 95 & 90 \\
\hline \multirow{2}{*}{\multicolumn{7}{|c|}{$\begin{array}{l}\text { Dow Contact Herbicide and Diesel oil } \\
\text { emulsions: } \\
0.68 \text { per cent } \mathrm{DN} \text { : }\end{array}$}} \\
\hline & & & & & & \\
\hline 19.3 per cent DO & 75 & 98 & 98 & 98 & 98 & 98 \\
\hline 9.3 per cent DO & 75 & 98 & 98 & 98 & 98 & 95 \\
\hline \multicolumn{7}{|l|}{0.34 per cent $\mathrm{DN}$ : } \\
\hline 9.6 per cent $\mathrm{DO} \ldots \ldots \ldots \ldots \ldots \ldots \ldots \ldots \ldots$ & 60 & 95 & 95 & 95 & 95 & 90 \\
\hline 4.6 per cent $D O \ldots \ldots \ldots \ldots \ldots \ldots \ldots \ldots$ & 60 & 95 & 95 & 98 & 95 & 95 \\
\hline \multicolumn{7}{|l|}{0.17 per cent $\mathrm{DN}$ : } \\
\hline 4.8 per cent DO $\ldots \ldots \ldots \ldots \ldots \ldots \ldots \ldots$ & 40 & 90 & 95 & 95 & 95 & 95 \\
\hline 2.3 per cent $D O \ldots \ldots \ldots \ldots \ldots \ldots \ldots \ldots$ & 40 & 90 & 95 & 95 & 98 & 98 \\
\hline \multicolumn{7}{|l|}{0.08 per cent $\mathrm{DN}$ : } \\
\hline 2.4 per cent $\mathrm{DO} \ldots \ldots \ldots \ldots \ldots \ldots \ldots \ldots \ldots \ldots \ldots$ & 20 & 75 & 90 & 90 & 90 & 90 \\
\hline 1.2 per cent $\mathrm{DO} \ldots \ldots \ldots \ldots \ldots \ldots \ldots \ldots \ldots$ & 20 & 75 & 90 & 90 & 90 & 90 \\
\hline
\end{tabular}

- Volume applied per culture, $10 \mathrm{ml}$.

tions, several combinations were obtained. These were designed to compare in concentration with standard dilutions of Dow Contact Herbicide, a proprietary mixture containing dinitro-sec-butylphenol in oil with added stabilizer. Table 62 presents the results.

As these data show, a fourfold reduction of oil concentration from 19.3 per cent to 4.3 per cent has less effect than a fourfold reduction in concentration of the dinitro compound. On the other hand, a twofold reduction in dinitro concentration changed the toxicity very little; further reduction had an appreciable effect. The evident conclusion is that the dinitro concentration of the solution as used in the field should be not less than $1 / 3$ per cent; the oil 
concentration may vary through rather wide limits without seriously affecting results. These conclusions agree with field experience. On broad-leaved weeds the contact herbicide, at $1 / 3$ per cent dinitro and around 3 per cent oil, is effective; on grasses, as in table 62, the kill is not complete. Experience has shown that increasing the dinitro concentration has little benefit as far as grasses are concerned; increasing the oil content to around 10 per cent provides the necessary qualities to make the injury complete. Judging from the experiments cited in this publication, the extent of kill on grasses is a matter of spreading and penetration of the spray solution rather than one of absolute toxicity.

The fortifying of oils with substituted phenol compounds has a single purpose-namely, to increase toxicity so that a smaller volume will be required per unit area. If the phenolic toxicant is less expensive per unit of toxicity, two savings are made : less oil is used; less volume need be hauled, transferred, and pumped through the spray rig.

Volume Relations of Fmulsions. Where the vegetative growth is rank, there is a definite limit to the reduction in volume that may be utilized; if a relatively large volume is required, the oil carrier may be used in greater amount, or the highly fortified oil may be extended by emulsification. If grasses make up a large portion of the vegetation being treated, the oil concentration in the emulsion should be kept above 6 per cent by volume; 10 per cent is better. Where the growth is largely broad-leaved weeds, the oil content may be reduced to as low as 2 per cent of the emulsion. Or the oil solution may be applied directly in low volume. For example, a fortified oil has been applied by airplane at a rate of 15 gallons per acre to control young weed growth in a field where onion bulbs had been planted for seed production. Protracted rains had rendered the field too muddy to spray by ground rig. The onion tops were slightly injured, but recovered completely. Weeds were set back until the field was dry enough for cultivation.

Fortified Diesel oil has proved valuable as a selective spray for controlling annual weeds in alfalfa fields. Tried first in 1945, this method was used on several thousand acres of alfalfa during the 1946 season. It has a twofold benefit : it eliminates weeds in the first cutting, rendering this cutting one of the most valuable; tillage operations that tend to spread alfalfa wilt may be avoided. Spraying was done both by ground rigs and by airplane, and applications were made (in central California) in January and February while the alfalfa was dormant.

Oil Carriers for 2,4-D. Oils offer promise as carriers for the new 2,4-D weed killers. An experiment using the methyl ester of 2,4-D in Diesel oil, stove oil, kerosene, and $n$-cetane on nut grass gives definite indication that the nontoxic carriers are most effective. The oil toxicity of the first two apparently interfered with the action of the 2,4-D: the nut-grass plants resprouted promptly and vigorously, whereas those sprayed with the kerosene and cetane solutions, though they died slowly, did not resprout. Aqueous sprays of the salts of 2,4-D have proved less effective on nut grass than these oil solutions of the ester. Even though emulsified with small amounts of Diesel oil and stabilized with wetting agents that materially improve the spreading and penetrating powers, the aqueous solutions have had less lasting effects. 
Several observers have reported that addition of small amounts of oil to aqueous solutions of 2,4-D increases toxicity, presumably owing to an improvement in spreading and penetration. This effect has been most pronounced on such weeds as cattail, tule, bur-reed, and similar species that are difficult to wet with straight aqueous sprays. Diesel and stove oils have been used for this purpose. The experiments on nut grass indicate that kerosene would be more effective because the acute toxicity of the less refined oils causes rapid injury and prevents translocation of the 2,4-D.

\section{DISCUSSION OF OIL TOXICITY}

Anyone familiar with toxicity testing will see that the foregoing text is a progress report. Although many of the questions that prompted the work have been answered, as many or more new problems have been posed. Most of the answers that have been given are empirical; they are practical answers to the grower's immediate problems. For instance, we now know that stove oil is suitable for selective weeding in carrots because it falls within the proper gravity range; Diesel oil is too heavy and causes chronic toxicity to which the crop plants are not tolerant; a fraction even lighter than stove oil would be highly desirable (more selective and less persistent) ; the principal drawbacks in the use of such a fraction are increased cost and the hazard of fire from its low flash point and high volatility. ${ }^{11}$

Diesel oil is valuable as a general contact herbicide because of its low interfacial tension on plants and because its content of chronic toxicants is effective against grasses. Although highly aromatic residues are somewhat more active than Diesel oil, they have little practical advantage because of their limited covering power; their high toxicity cannot be completely utilized without the use of extenders; emulsification does not solve the problem where grasses are involved; dilution with oil is too expensive under a price ceiling set by Diesel fuel.

One may greatly increase the acute toxicity of any oil by adding fortifying agents. Such fortified oils may be used advantageously where large weedy grasses are not a major part of the weed population. They have proved effective in the weeding of ditchbanks; they kill all the weeds where wild carrot, fennel, and other oil-tolerant species are involved; they shorten the time required for killing weeds for mosquito control; they have solved the problem of controlling small annual weeds in dormant alfalfa and among onion bulbs planted for seed production. By means of airplanes, large alfalfa acreages can be covered in a short time and application can be made when moisture conditions prevent the operation of a ground rig.

The examples given above illustrate some of the information that has resulted from the research on oils. There still remain many problems concerning the fundamental responses of plants to oil application. Foremost among these is the nature of oil toxicity.

Nature of Oil Toxicity. As pointed out by de Ong, Knight, and Chamberlin (1927), oils may have two rather distinct types of toxicity : acute, caused by low-boiling oils; and chronic, caused by high-boiling fractions. Acute toxicity is usually apparent within 24 hours and is often fatal within 48. Chronic

\footnotetext{
${ }^{11}$ See footnote 6, p. 84.
} 
injury causes defoliation of citrus trees that begins within a few days and continues for weeks. It is evidenced in weed cultures as a slow yellowing of leaves, killing of the meristems of grasses, stunting, increased susceptibility to mildew infection, and finally death. Oils that are chronically toxic to grasses often cause a shift from negative to positive geotropism; whether this physiological response has any direct relation with chronic toxicity is yet to be determined.

De Ong, Knight, and Chamberlin (1927) concluded that the severe injury to citrus trees by the use of lubricating oils was associated with a high content of unsaturated hydrocarbons; sulfuric acid treatment of an oil removes aromatic, olefinic, resin, and sulfur compounds; such treatment has greatly reduced injury from the oils. As these writers have pointed out, among unrefined oils low-boiling ones are safer to use than heavier fractions because they evaporate quickly; but, for this same reason, they are not effective against scale insects.

Tucker (1936), from studies on the toxicity of fairly heavy oils (viscosity, Saybolt at $100^{\circ} \mathrm{F}, 77$ to 420 sec.) on apricot leaves, concluded that the toxic agents were asphaltogenic acids, generated in the oils as a result of exposure to light and oxygen. He proposed that unsaturates are no more toxic than saturates but that formation of asphaltogenic acids is proportional to the amount of unsaturates present in a fraction.

Since Tucker worked only with oils that caused chronic toxicity, most of them highly refined, one can understand the reason for his conclusions. In contrast, many experiments reported in the present paper, including some with unrefined light fractions, many with pure compounds, and some with both unrefined and refined heavy fractions, prove that unsaturates are much more toxic than saturates.

Types of Oil Toxicity. An analysis of our results in the light of Tucker's conclusions will emphasize the fact that several types of toxicity are involved:

1. Acute toxicity caused by low-boiling unsaturates. This type is exhibited by gasoline and the light ends of stove oil ; also by benzene, toluene, xylene, cyclohexene, cyclohexane, and many of their derivatives. It is shown in extreme form by Edeleanu extract and Avon Weed Killer. This is the toxicity to which members of the carrot family are relatively immune. Such toxicity is violent and nonpersistent because the compounds causing it are relatively volatile and soon leave the plant.

2. Chronic toxicity due to high-boiling unsaturates. This type results from application of Diesel oil and heavy fuel oils. It may also be caused by highboiling aromatic hydrocarbons, such as the isopropyl benzenes. Its expression may vary through a wide range of time if the toxicants vary widely in concentration in different fractions. For instance, plants may be rapidly killed by heavy aromatic and olefinic fractions that are high in these unsaturates; they may require many days to respond to low concentrations when these are diluted with compounds of low toxicity. Though differences in tolerance occur among plants, even carrots succumb to chronic toxicants in sufficient concentration. Grasses are particularly susceptible to them. Symptoms may develop slowly; they consist of chlorosis, killing of meristems, cessation of growth, an unthrifty appearance, and high susceptibility to fungus attack. 
3. Acute toxicity shown by highly refined fractions of low-boiling petroleum distillates that have been exposed to light for some time. This type of toxicity develops in gasoline and kerosene upon standing exposed to light. It is nonselective, violent, and nonpersistent because it is caused by compounds of high volatility. It develops, for example, in the isoparaffinic fractions reputed to be 100 per cent unsulfonated, and also in the unsulfonated residues of gasoline and kerosene. It was absent in stove oil, and stove-oil temperature cuts.

4. Chronic toxicity shown by highly refined fractions of high-boiling petroleum distillates that have been exposed to light. This toxicity developed in mineral seal oil, heavy isoparaffin, and - to a slight extent-in $n$-cetane. This is the type of toxicity studied by Tucker and attributed to asphaltogenic acids. It is undoubtedly caused by some products of oxidation of the oils; the exact nature of these products has not yet been determined.

The idea that asphaltogenic acids may form from oils after application to plants challenges the whole concept of chronic toxicity. One might legitimately ask: "How can it be proved that compounds originally present are responsible for chronic toxicity when time sufficient for asphaltogenic acid formation must be allowed for development of symptoms?"

There are two answers to this question. As revealed by the experiments with pure compounds, a series of substituted benzenes may show varying degrees of toxicity according to the extent of substitution. It does not seem probable that asphaltogenic acid formation would depend in the same way upon these substitutions.

A second, and probably sounder, answer is that relatively unrefined fractions such as Diesel oil and U.S. no. 1 fuel oil produce chronic toxicity and none of these unrefined fractions gained toxicity from standing in the light. They must, therefore, have contained the toxicants originally.

Oxidation of Oils. This discussion naturally evokes two questions: What is the nature of the acquired toxicity of oil fractions? Why is it acquired only by highly refined oils? Much research by oil chemists indicates that deterioration of lubricating oils and "staling" of gasoline and kerosene result from oxidation. Dornte (1936) showed that oxidation of white oils follows the general equation

$$
\begin{aligned}
& \begin{array}{l}
V^{\frac{1}{2}}=K t+n \\
\text { Where } \\
\begin{aligned}
V & =\text { total volume of oxygen absorbed (at normal temperature and pres- } \\
& \text { sure), ce per } 100 \text { grams of oil }
\end{aligned} \\
t=\text { time in hours } \\
K=\text { a constant that characterizes the rate of oxidation and } \\
n=\text { another constant related to inhibition of the reaction by foreign } \\
\quad \text { or natural inhibitors. }
\end{array}
\end{aligned}
$$

By plotting the square root of volume of oxygen absorbed against time, Dornte found that a straight-line relation is obtained having the slope $K$, with $n$ as the point where the line intercepts the time axis.

When 100 p.p.m. of the antioxidant phenyl-a-naphthylamine was added, the value of $n$ was about 20 hours. After this period, oxidation proceeded at 
nearly the normal rate. The values of $K$ (reaction rate) varied little with changes in partial pressure of the oxygen, being proportional to the $1 / 4$ power. At any time in the reaction about 25 per cent of the total oxygen absorbed was found as peroxide, 6 per cent appeared as water, and 6 per cent as acids.

From Dornte's results it is apparent that the oxidation of white oils is an autocatalytic process; that there is an induction period due to naturally occurring antioxidants; that one may lengthen this period by adding antioxidants; that the reaction proceeds at a nearly normal rate after the induction period has passed; and that the rate of the reaction varies little through a wide range of oxygen tensions.

Larsen and Armfield (1943), working with lubricating oils, found that oxidation stability of an oil is not achieved by removal of "unstable aromatics" (by refining), but rather that it results from the presence of natural antioxidants that stabilize the relatively reactive hydrocarbons constituting the bulk of such an oil. These results are confirmed by the work of Fenske and his coworkers (1941) and of von Fuchs and Diamond (1942). The effects of natural sulfur compounds in inhibiting oxidation of oil, as reported by Denison (1944), should be investigated from the standpoint of changes in toxicity to plants.

Evidently the aliphatic hydrocarbons are more reactive than has been assumed in the past; the removal of natural inhibitors by refining procedures brings about oxidation reactions that alter the chemical as well as the physical properties of an oil. Such reactions are apparently induced by light and temperature, and although oxygen is required, apparently certain changes (induction) may go on with only a limited supply present, leading up to a very rapid change when the oil is brought in contact with an unlimited supply. This - later active stage may respond to metallic catalysts (Larsen and Armfield, 1943).

Tucker, in using highly refined high-boiling oils, was undoubtedly dealing with toxicity that resulted from oxidation. He was therefore justified in concluding that toxicity was due to asphaltogenic acids (oxidation products) and not unsaturates. It should be recognized, however, that at least three other types may occur as listed under paragraphs 1, 2, and 3 (p. 147 to 148).

On the Production of a Nontoxic Diluent. These considerations explain many of the results obtained in the experiments that have been described. The gains in toxicity by many of the refined oils were probably due to oxidation. The production of a nontoxic diluent therefore must involve two steps : first, production, by refining procedures or by synthesis, of a pure aliphatic oil ; and second, the addition of a suitable antioxidant that is itself nontoxic at the concentration required. Furthermore, the time-temperature relation for the induction period for this product must be determined so that adequate storage conditions may be provided and the maximum "safe period" for using the oil determined. An antioxidant that would prolong the induction period for light catalysis of the oxidation reaction would improve such a diluent.

The natural occurrence, in oils, of antioxidants that protect against oxidation would seem to explain why stove-oil fractions did not gain toxicity upon storage in the light. Kerosene, gasoline, isoparaffin, and other highly refined products did gain in toxicity because they lacked these natural inhibitors. 
The relation of the induction period and the small effect of oxygen tension upon the oxidation reaction of kerosene clarified the increase in toxicity during storage. The oil had stood in the dark exposed to the air for some time before being bottled and placed in the light. Undoubtedly it had become saturated with oxygen. When it was placed in the light, oxidation presumably started and carried on through the induction period. When the oil was applied to the plant (where it was spread in a thin film in contact with the air), the reaction undoubtedly speeded up, passing into the rapid phase with the production of increasing amounts of peroxides. Tucker (1936) showed that whenever the peroxide content exceeds 0.5 per cent, toxicity to apricot leaves becomes evident. Since oxidation may be autocatalytic, the rapid killing by these stored oil samples seems clearly to result from the products of this reaction.

Oil Selectivity. Another point of interest in the herbicidal use of oils is their selective action. As pointed out previously (Crafts, 1946), all selectivities of herbicides are relative, based on the dosage rate of the particular constituent to which the crop plant is resistant. Benzene, used pure for a sufficient exposure period, will kill grass, flax, and carrots ; at a lower dosage rate it will kill grass and flax only; at a lower rate only grass. Gasoline will kill flax and grass; if diluted it injures only the grass. Kerosene, if fresh, will kill grass while causing no injury to flax and carrots. The compounds responsible for this injury are not selective; the natural selectivity of the fractions results from the particular dosage provided by each; not only concentration but exposure time as determined by volatility is involved.

Character of Oil Toxicity. Oil toxicity to many plants seems not to follow a linear relation but rather to involve threshold values. For instance, straightrun gasoline may contain around 20 to 30 per cent aromatics. At half strength it will not kill grass; at full strength it kills grass but not carrots; even at six times the normal dosage it will not injure carrots ; apparently the moistening film will not hold enough toxicant to exceed the threshold of toxicity to these plants.

The threshold of toxicity involves not dosage alone but time and temperature also; apparently an expression of total chemical activity is involved. In cool weather, carrots will not be injured by stove oil with a gravity rating of $38^{\circ}$ or higher at 100 gallons per acre; on a hot day such an application may cause some damage; similar damage may result when 150 gallons is used per acre on a cool day. Time, which affects exposure, enters the problem through the gravity of the oil. Gasoline at 150 or 300 gallons per acre will not injure carrots for it evaporates before injury can occur. If stove oil having a gravity rating of $34^{\circ}$ is used, it will injure at 100 gallons per acre : it remains on the plants for many days, and, though its unsaturate content may be no higher than that of gasoline, it injures because of long exposure.

The exact nature of oil phytotoxicity is not well understood. The idea that tissues are killed by suffocation seems no longer tenable. In experiments recorded by Bailey (1930), cells were living after being surrounded with white medicinal oil for 500 hours. If suffocation were possible, these cells should have died.

If young active barley plants are sprayed with benzene, very soon an odor 
similar to that of macerated leaves is discernible. Evidently, substances are released from the cells that ordinarily are freed only by complete destruction. Whereas the tissues will recover from a light spraying, prolonged exposure results in death. This would suggest that acute toxicity by unsaturates results from a rapid denaturing of the cell protoplast, a release of certain aromatic constituents, and finally complete disruption of the cells. The chlorophyll may become discolored within a few minutes in bright sunlight. Carrots give the same response, but somewhat more slowly.

Symptoms of chronic injury have been described on pages 146 to 148 . They differ in many respects from those of acute injury ; they involve the physiology as well as the biochemistry of the cells and tissues.

Toxicity due to oxidation of oils is different in nature from the type described above; it is less rapid than that from low-boiling aromatics, but very violent in its action. It is also nonselective at the dosage rates studied; apparently it results from a chemical mechanism involving qualities other than unsaturation.

Besides the applications that have been pointed out from place to place in this paper, the following suggestions have evolved in the study of oxidation. In research with oils it seems imperative that all samples be accurately labeled as to source, time of receipt, chemical nature, physical properties, and the like. Furthermore, if needed for future work these should be kept in dark bottles in a cool, dark place; and they should be tested periodically by some standardized procedure, not only for chemical changes but for attendant changes in toxicity.

If special oil fractions for spraying carrots, flax, or onions are produced will the addition of antioxidants protect them against increases in toxicity by oxidation? Where fuel fractions are widely used as general contact herbicides, might not their toxicity be considerably increased if oxidation could be induced? This result may prove particularly valuable if, in the future, improved fuels are freed of naturally occurring antioxidants by refining processes.

In producing spray oils for horticultural use, the manufacturer is faced with a dilemma. If little refining is used antioxidants will not be removed; but neither will unsaturates that are inherently toxic. If the oil is highly refined to remove all unsaturates, oxidation may render the oil toxic to foliage. Might not the answer to this problem be the production of highly refined oils of low unsaturate content and the addition to these of antioxidantseither natural, if they can be extracted without breaking down; or, if need be, synthetic?

Many other practical questions may be pointed out. Selectivity of oils, first used in killing weeds in carrot and celery crops, can be shown to function in flax and onion cultures in the greenhouse; barley seedlings have even been killed in cultures containing mustards and wild lettuce. Can this selectivity be carried to potatoes, cabbage, broccoli, cauliflower, beets, lettuce, and other truck crops in the field? These and many other questions present themselves for future study. They point out a fascinating field for research. Their answers will constitute a valuable body of knowledge for immediate application in practical agriculture. 


\section{SUMMARY}

Oil Fractions. The tests on the relation of toxicity to boiling range have shown that two types of toxicity-acute and chronic-are caused by oils. Starting with the light fractions, acute toxicity increases with increased boiling temperature through the three light fractions of gasoline and reaches a maximum in the fourth fraction that boils between $330^{\circ}$ and $420^{\circ} \mathrm{F}$. Of the stove-oil fractions, acute toxicity is highest in the lightest, which boils between $320^{\circ}$ and $390^{\circ} \mathrm{F}$, but is practically equaled by the second fraction, boiling between $390^{\circ}$ and $425^{\circ} \mathrm{F}$.

Chronic toxicity begins to show up in the third stove-oil fraction and increases with increasing boiling temperature through fractions 2,3 , and 4 of Diesel oil. U.S. no. 1 fuel oil is high in chronic toxicity; but its high viscosity interferes with penetration, so that a mixture of 1 part with 3 parts of kerosene makes a more toxic material.

The refined fractions kerosene, odorless kerosene, and mineral seal oil are devoid of acute toxicity. All, however, show a certain degree of chronic toxicity, particularly against grasses. Mineral seal oil, the heaviest, was toxic to mixed weeds, grass, carrots, and flax by the seventh day of the test and more so as time went on. No one of the natural or synthetic fractions tested was entirely free of phytocidal effect.

Toxicity of fractional distillates of gasoline increases with weight of the fractions. Grass was killed by three heavy fractions and severely injured by the lightest. Onions recovered from injury by all fractions.

Cracked gasoline proved more toxic than straight-run.

Acid Treatment and Solvent Extraction. Acid treatment, by breaking down unsaturated compounds in petroleum fractions, reduces toxicity. Unsulfonated residues of stove oil produced by treatment with concentrated sulfuric acid were most toxic when made from the light cuts. Unsulfonated residues from heavy stove-oil fractions and Diesel-oil fractions were very low or completely lacking in toxicity. Carrots were not injured by unsulfonated residues from any of the oil fractions. The unsulfonated residue of heavy isoparaffin was nontoxic in the 8-day test period. In a 40-day period, unsulfonated residues from both stove oil and isoparaffin killed barley plants.

Unsulfonated residues of gasoline were more toxic than those of stove oil; those of cracked gasoline more than those of straight-run.

Solvent extraction removes the olefinic and aromatic compounds from petroleum fractions. Edeleanu extract and TS-28, a technical solvent prepared from this extract by fractional distillation, are both extremely toxic to carrots as well as to weeds. Avon Weed Killer, a residue remaining after the removal of valuable solvents from Edeleanu extract, is also very toxic. It is somewhat more toxic than the original extract to carrots, probably because it is heavier and thus more concentrated in chronic toxicants. When fractionated by distillation, the heavier cuts of both Edeleanu extract and Avon Weed Killer are more toxic.

When kerosene distillate is extracted repeatedly, the first extracts are most toxic. The final raffinate is like odorless kerosene in toxicity-that is, very low.

Coal-tar still residues are highly aromatic, hence very toxic. Refining of one 
such material reduced somewhat the acute toxicity, but increased the chronic toxic properties.

An attempt to separate olefins and aromatics from a gasoline fraction by acid treatment resulted in greatly reduced toxicity but no clear separation of compounds. Detailed study of heavy olefinic and aromatic fractions proved the latter to be the more toxic and indicated them to be somewhat more selective than olefins between carrots and grass.

A naphthenic fraction proved intermediate in toxicity ; a heavy isoparaffinic fraction nontoxic; and a fraction called naphthone A very toxic. A highsulfur gasoline was very toxic if used without dilution, and $n$-cetane proved useful as a nontoxic diluent.

Toxicity and Boiling Range of Edeleanu Extract. When a series of temperature cuts of Edeleanu extract were tested for toxicity to plants, the heavier cuts invariably proved most toxic.

Storage and Refluxing. Gasoline samples gained in toxicity upon standing in the light in clear glass bottles. Refluxing of samples lowered their toxicity slightly ; if air was passed through the apparatus during refluxing, the toxicity was a bit higher. Refluxing caused the samples to darken.

Upon standing in the light, samples of both kerosene and gasoline increased in toxicity; this toxicity was not selective on carrots. The theory is proposed that these changes result from formation of peroxides.

Pure Compounds. The toxicity of simple aromatic hydrocarbons increases with increasing substitutions in the benzene ring, as do their boiling points.

Xylene was equal in toxicity to gasoline, but not to a commercial aromatic solvent or stove oil. At the proper concentrations, xylene killed weeds in carróts selectively.

Tests on iso-, diiso-, triiso-, and tetraisopropylbenzenes proved that toxicity increases, in a general way, with increasing substitution. Both acute and chronic toxicity occurred. Since, however, the tests differed in detailed results, further work will be required for a clear picture of the relation.

Onions and carrots both tolerate the aromatic hydrocarbons.

Four chemically pure aliphatic hydrocarbons proved relatively nontoxic on fairly mature plants. These should prove useful as diluents in toxicity tests on aromatic and olefinic compounds.

Three saturated-ring carbon compounds proved toxic to plants.

Four mercaptans proved too low in toxicity to be of any herbicidal value.

In extended tests on $n$-hexane and $n$-cetane, the first caused acute injury, the second chronic injury, to young succulent flax and barley plants. Unsulfonated residues of stove oil and of the heavy isoparaffin that had been stored for several months in the light proved toxic, the latter to flax as well as barley.

Selectivity of Oils. Xylene will kill weeds selectively in carrots, with little or no harm to the latter. Onions and flax likewise manifest tolerance to the toxic effects of xylene. Grasses seem particularly susceptible to the toxic materials in oils.

Olefinic and aromatic compounds from oils also show selective action between weeds and the crop plants carrots and flax.

Onions tolerate both gasoline and stove oil. Fractions corresponding to the middle boiling range of gasoline apparently display the greatest selec- 
tivity. Gasoline proved better than stove oil and Diesel oil for spraying onions in the field.

Weeds vary with respect to their reaction to oil sprays. Grasses are particularly susceptible to oil injury; mustards and fiddleneck are also easily destroyed; pigweeds, goosefoot, and lambs'-quarters are intermediate; sow thistle and wild lettuce are hard to kill; dense, matted chickweed is also difficult.

Kerosene, though initially low in toxicity, by slow chronic action kills grasses without injury to several crop plants. It may prove a valuable selective spray.

Physical Properties of Oil and Application Methods. Oils generally used for weed control have low viscosities and surface tensions. As compared with aqueous solutions they wet plants exceedingly well. They spread and creep downward; they penetrate the cuticle and come into intimate contact with the living protoplasm of cells.

Plants having spreading, open structure may be almost completely wet by aqueous sprays. Grasses are difficult to wet with water; but an oil, because of its physical properties, can wet their surfaces, creep into their crowns, and penetrate their cuticles. This may explain, in part, the specificity of oils for grasses.

Diesel oil sprayed on the top half of 10 -inch barley plants ran down the leaves and stems and killed the crowns if the cultures were placed in a vertical position. Creeping occurred to a distance of only 2 inches if the cultures remained in a horizontal position.

When oils were applied to barley plants by the depositing of several drops in the funnel-formed top leaves, gasoline proved most toxic. When oils were applied as a spray to plants in a vertical position, kerosene was most toxic, followed by Diesel oil. The latter killed more slowly; but both agents effected complete kills. Applied to the crowns by means of a brush, gasoline and kerosene penetrated and killed the plants ; Diesel oil caused injury but did not kill.

The properties inherent in Diesel oil as a result of refining make it almost ideal as a general-contact spray material. If improvement of this oil for Diesel-fuel purposes involves removal of olefinic and aromatic fractions, the herbicidal value will be reduced.

Stove oil as produced commercially meets very well the requirements for a selective oil in vegetable crops. A slight drop in its A.P.I. gravity rating or the removal of unsaturates would render this fraction less satisfactory.

In the future production of herbicidal oils, manufacturers should balance toxicity and spreading and penetrating powers in order to meet the requirements of particular weeds and crops.

Properties of Emulsions. Emulsifying of Diesel oil has not proved useful in weed control.

Stove-oil emulsions proved somewhat more toxic than straight stove-oil sprays of the same oil volume. Selectivity between carrots and weeds was reduced.

Emulsions of Avon Weed Killer and water were selective as between carrots and weeds. Stabilizing the emulsion with Vatsol increased the toxicity. The unstabilized emulsion failed to kill broad-leaved weeds. 
Xylene and a technical solvent obtained by distillation of Edeleanu extract both proved selective against weeds in onions. Emulsions killed faster than straight oil sprays, but penetrated less well. Grasses recovered from injury by emulsions but died from oil sprays.

In tests on emulsions of normal Avon Weed Killer and of a type that forms an invert emulsion, no significant difference in toxicity was found.

Comparison of emulsions of Diesel oil and water, with and without the addition of sulfur, proved that sulfur increases appreciably the toxicity of such a mixture. Two grams of sulfur was roughly equivalent to $166 \mathrm{ml}$ of Diesel oil. Plants sprayed with the emulsion containing sulfur became bleached during the second week after treatment.

Fortified Oils and Oil Emulsions. Acute toxicants that occur naturally in petroleum oils are of a low order of toxicity. Chronic toxicants are more effective but slower in their action.

Nitro- and chloro-substituted phenols carry high acute toxicity. They are valuable for fortifying oils of low acute or chronic toxicity.

The higher the content of aliphatic hydrocarbons in an oil, the poorer that oil's solvent properties for substituted phenols.

Among the dinitro-substituted phenols, the longer the substituted aliphatic chain the more soluble the compound is in oils.

In emulsions containing salts of substituted phenols in the aqueous phase or the parent compounds in the oil phase, toxicity increases with increasing oil content, but not always in a direct linear relation. When the oil content reaches a volume percentage of 6 or greater, killing by the emulsion approaches that of straight oil, provided the phenolic toxicant is above a limiting concentration. Where grasses mainly are concerned, an oil concentration up to 10 per cent is preferable.

Toxicity, of oils may be greatly increased by fortification with phenolic toxicants. Such fortified oils may be applied direct at low volume rates, as by airplane; they may be extended by dilution with more oil; or they may be extended by emulsification with water. Preference depends largely upon the weed species being treated and upon relative costs of materials and application.

Oils also serve as carriers for 2,4-D. A low-toxicity kerosene has been used as a carrier for the methyl ester of 2,4-D on nut grass. Emulsions of Diesel or stove oils and 2,4-D salt solutions have been sprayed on cattails, tules, and bur-reed. Low-toxicity oils seem best as carriers of 2,4-D where this chemical is used on perennial weeds. Oil toxicity interferes with translocation of 2,4-D to the roots of such plants. 
Bailey, I. W.

\section{LITERATURE CITED}

1930. The cambium and its derivative tissues. V. A reconnaissance of the vacuome in living cells. Ztsch f. Zellforsch. u. Mikros. Anat. 10:651-82.

CRAFTS, A. S.

1946. Selectivity of herbicides. Plant Physiol. $21: 345-61$.

Crafts, A. S., and R. N. RAYNor.

1944. Weeding onions. Western Grower and Shipper 15(9):10-11, 26-28.

Denison, G. H., JR.

1944. Oxidation of lubricating oils: Effect of natural sulfur compounds and of peroxides. Indus. and Engin. Chem. 36:477-82.

De Ong, E. R., Hugh Knight, and Joseph C. Chamberlin.

1927. A preliminary study of petroleum oil as an insecticide for citrus trees. Hilgardia $2(9): 351-84$. (Out of print.)

DORNTE, RALPH W.

1936. Oxidation of white oils. Indus. and Engin. Chem. 28:26-30.

Fenske, M. R., C. E. Stevenson, N. D. Lawson, Glenn Herbolshfimer, and E. F. Koch. 1941. Oxidation of lubricating oils: Factors controlling oxidation stability. Indus. and Engin. Chem. 33:516-24.

Fuchs, G. H. von, and H. Diamond.

1942. Oxidation characteristics of lubricating oils: Relation between stability and chemical composition. Indus. and Engin Chem. 34:927-37.

GrAY, G. P., and E. R. DE ONG.

1926. California petroleum insecticides: Laboratory and field tests. Indus. and Engin. Chem. 18:175-80.

LARSEN, R. G., and F. A. ARMField.

1943. Catalysis in the oxidation of lubricating oil. Indus. and Engin. Chem. 35:581-88. TUCKER, R. P.

1936. Oil sprays: Chemical properties of petroleum oil unsaturates causing injury to foliage. Indus. and Engin. Chem. 28:458-61. 
In order that the information in our publications may be more intelligible, it is sometimes necessary to use trade names of products or equipment rather than complicated descriptive or chemical identifications. In so doing it is unavoidable in some cases that similar products which are on the market under other trade names may not be cited. No endorsement of named products is intended nor is criticism implied of similar products which are not mentioned. 


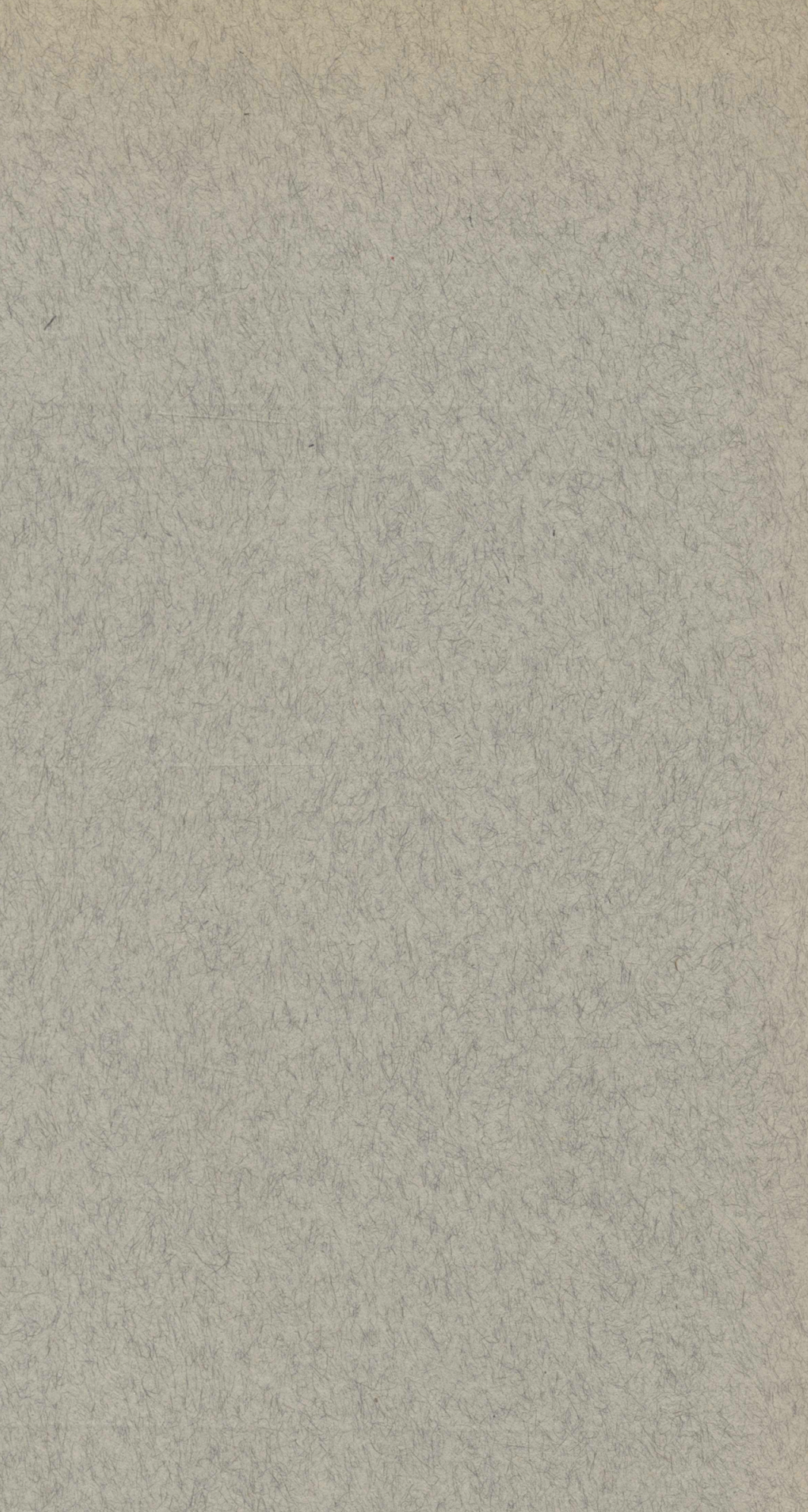

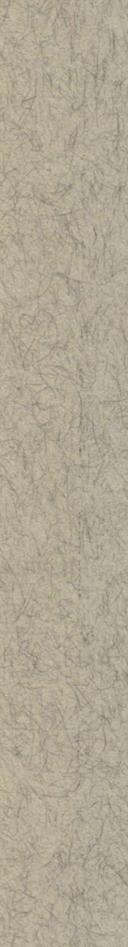

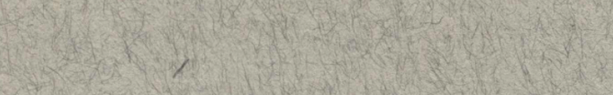

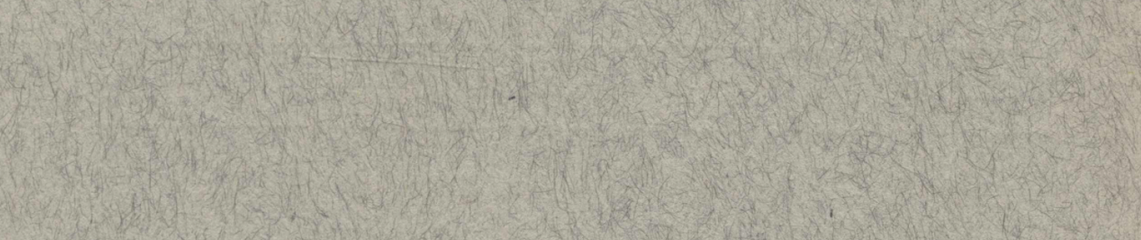

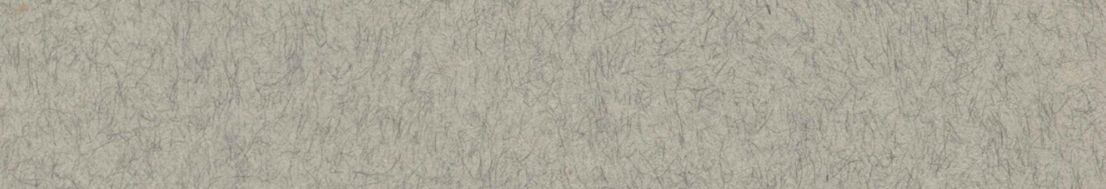
$\sin (x)=0$

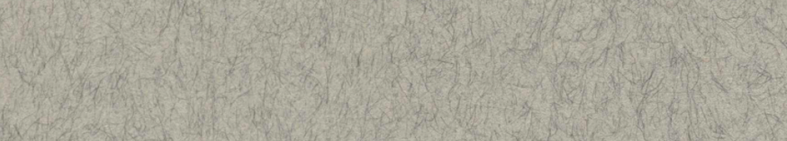

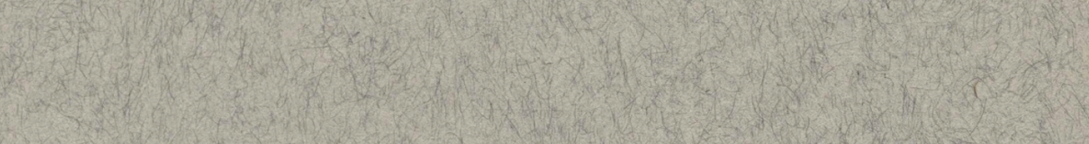

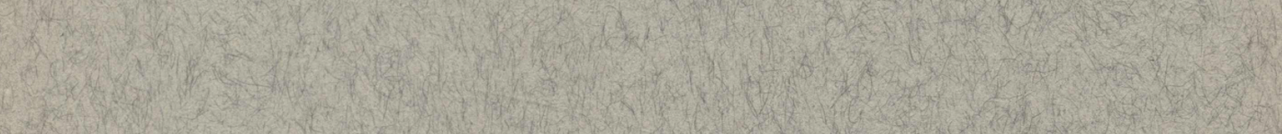

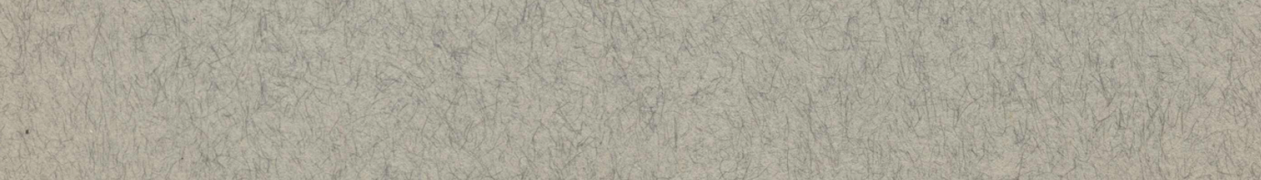
Non 